\title{
POTENCIAL GENÉTICO DE CRUZAMENTOS DIALÉLICOS PARCIAIS DE SOIA COM ÊNFASE NAS PRODUTIVIDADES DE GRÃOS E ÓLEO
}

\author{
DIEGO OMAR SOLDINI
}

Licenciado em Genética

Ciientador: Prof. Dr. NATAL ANTONIO VELlO

Tese apresentada ̀̀ Escola Superior de Agricultura "Luiz de Queiroz", Universidade de São Paulo, para obtenção do título de Doutor em Agronomia, Área de Concentração: Genética e Melhoramento de Plantas.

P I R A C I C A B A

Estado de São Paulo - Brasil

Dezembro - 1998 


\section{Dados Internacionais:de catalogação na Publicação (CIP) DIVISÃO DE BIBLIOTECA E DOCUMENTAÇÃO - Campus "Luiz de Queiroz"/USP}

\section{Soldini, Diego Omar}

Potencial genético de cruzamentos dialélicos parciais de soja com ênfase nas: produtividades de grăos e óleo / Diego Omar Soldini. . - Piracicaba, 1998.

so p.

Tese (doutorado) - - Escola Superior de Agricultura Luiz de Queirozic 19998

Bibliografia.

1. Correlação genética 2. Cruzamento dialélico 3. Expressão gênica 4. Germoplasma vegetal 5. Grăo 6. Interação genótipo-ambiente 7. Melhoramento" genético vegetal 8 . Óleo vegetal 9. Produtividade agricola 10. Soja I. Título

" CDD 633.34 


\section{POTENCIAL GENÉTICO DE CRUZAMENTOS DIALÉLICOS PARCIAIS DE SOJA COM ÊNFASE NAS PRODUTIVIDADES DE GRÃOS E ÓLEO}

\section{ERRATA}

\begin{tabular}{|c|c|c|}
\hline Página & Onde se lê & Leia-se \\
\hline v & combination & combining \\
\hline 4 & gordura de dendê & óleo de dendê \\
\hline 8 & $00,0,1,11, I I I, I V$ e $V$ & $00,0,1,11$, II e IV \\
\hline 14 & conducidos & conduzidos \\
\hline 30 & variedades & parentais \\
\hline $16 ; 29 ; 30 ; 59 ; 60 ; 76 ; 80$ & gij & sij \\
\hline
\end{tabular}




\section{AGRADECIMENTOS}

- À Coordenação do Subprograma Soja e à Direção da Estação. Experimental Agropecuária (EEA) Marcos Juárez, do Instituto Nacional de Tecnologia Agropecuária (INTA), pela oportunidade de realizar o curso de doutorado;

- Ao Conselho Nacional de Desenvolvimento Científico e Tecnológico - CNPq, pela concessão da bolsa de estudos;

- Ao CNPq, EMBRAPA, FAPESP e FINEP, pelo apoio financeiro das diferentes etapas das pesquisas que originaram o germoplasma utilizado neste rabalho;

- Ao Prof. Dr. Natal Antonio Vello; pela atenção; predisposição, orientação e conselhos;

- Ao Dr. Luiz Alberto Colnago da EMBRAPA - CNPDIA, São Carlos, pela atenção e colaboração com as análises de teor de óleo por Espectrômetro de Ressonância Nuclear Magnética (NRRR)

- Ao Dr. Lair C. Cabral da EMBRAPA - CTAA, Rio de Janeiro, pelas análises químicas do conteúdo 'de! đłeo' das amostras padrões para determinar a curva de calibração (NMR);

- Á funcionária da Biblioteca do Departamento de Genética, Silvana M. Gregório, pelas correções das reférềncias bibliográficas;

- Aos colegas Pós-Graduando Ângela C. de Almeida Lopes, Fábio Pandini e Maurisrael de $M$. Rocha, pela valiosas sugestões e correções do manuscrito da tese;

- Aos colegas Pós-Graduandos Fernando T. de Miranda, Gilberto K. Yokomizo e Maurisrael de $\mathrm{M}$. Rocha, pela valiosa colaboração fornecida no transplante da terceira época dos experimentos;

- Aos funcionários do Setor de Genética Aplicada às Espécies Autógamas, Antônio R. Cogo, Claudinei A. Didoné e Marcos C. Nekatschalow, pela permanente colaboração e valiosas sugestões no trabalho;

- A minha esposa Alejandra pela colaboração no preparo e edição da tese. 


\section{SUMÁRIO}

Página

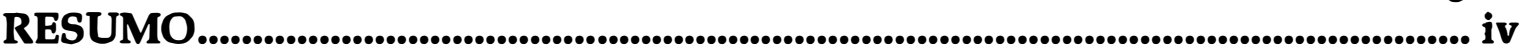

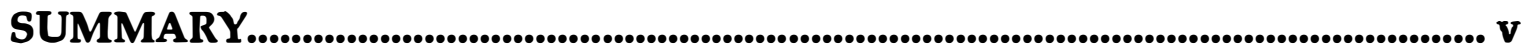

1 INTRODUÇÃO

2 REVISÃO DE LITERATURA...................................................................... 3

2.1 Projeções mundiais da produção e consumo de óleos vegetais.................................... 3

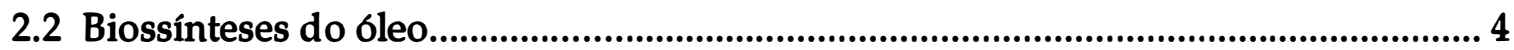

2.3 Contribuições à genética e melhoramento do teor de óleo............................................ 7

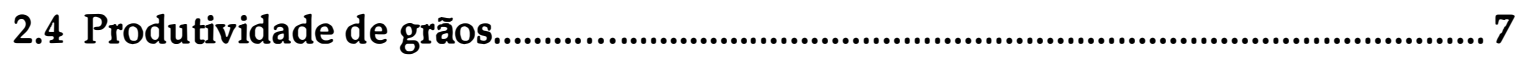

2.5 Ações gênicas, correlações e interações genótipos $x$ ambientes...................................... 9

3 MATERIAL E MÉTODOS.... ............................................................................ 11

3.1 Material genético.......................................................................................................... 11

3.2 Procedimento experimental..................................................................................... 13

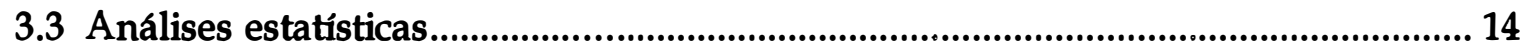

3.3.1 Análises de variância individuais e conjuntas.......................................................... 14

3.3.2 Análises de correlações parciais............................................................................... 15

3.3.3 Análises dialélicas.................................................................................................. 15

4 RESULTADOS E DISCUSSÃO

4.1 Análises de variância individuais................................................................................. 19

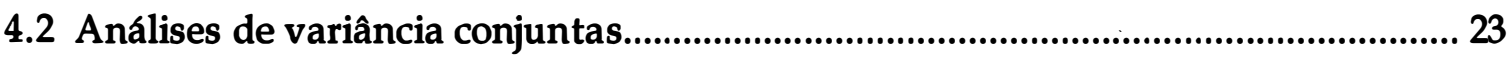

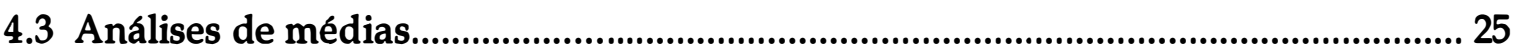

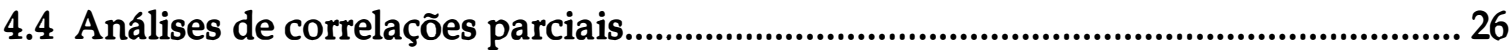

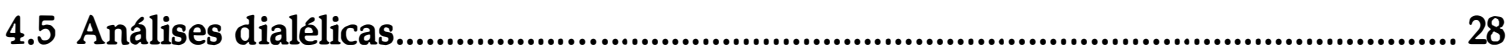

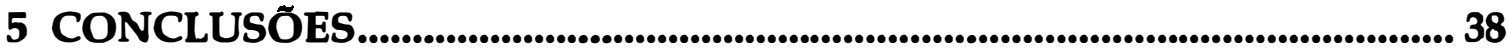

REFERÊNCIAS BIBLIOGRÁFICAS........................................................... 40

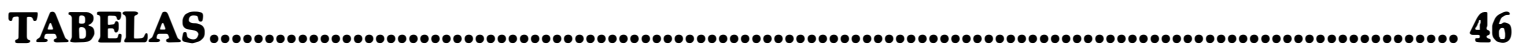

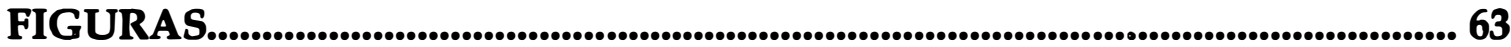

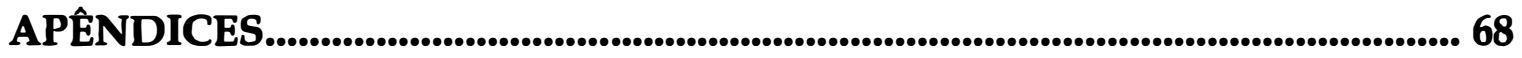

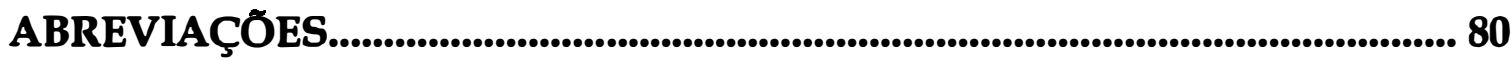




\title{
POTENCIAL GENÉTICO DE CRUZAMENTOS DIALÉLICOS
}

\author{
PARCIAIS DE SOJA COM ÊNFASE NAS \\ PRODUTIVIDADES DE GRÃOS E ÓLEO
}

\author{
Autor: Diego Omar Soldini \\ Orientador: Prof. Dr. Natal Antonio Vello
}

\section{RESUMO}

As interpretações biológicas das estimativas dos efeitos de interações ambientais, correlações genéticas, ações gênicas e distribuições alélicas possibilitam o aumento das probabilidades de êxito na obtenção de indivíduos com expressões agronômicas favoráveis. Em delineamento de blocos ao acaso, foram avaliados 53 tratamentos ( 40 populações de plantas $F_{2}$ derivadas de cruzamentos dialélicos parciais $5 \times 8$, e 13 parentais) em três épocas dentro do periodo normal de semeadura (Novembro) no município de Piracicaba - SP, Brasil $\left(22^{\circ} 42^{\prime} 30^{\prime \prime}\right.$ de latitude Sul, $47^{\circ} 38^{\prime}$ 30" de longitude Oeste), no ano agrícola de 1997/98. A parcela experimental foi representada por 12 covas de plantas individuais espaçadas de $0,8 \times 0,8 \mathrm{~m}$ e num total de seis repetições ( 2 repetições $\times 3$ épocas de semeadura) foram pesquisadas 72 plantas por tratamento. Os resultados permitem concluir que o incremento da produtividade de óleo (PO) depende de mudanças nas freqüências alélicas para produtividade de grãos (PG). Ambos os índices de produtividade de grãos ( $\mathrm{IPG}_{(1)}$ e $\left.\mathrm{IPG}_{(2)}\right)$, associados à eficiencia da planta no tempo e no desenvolvimento vegetativo, monstram-se úteis como critérios de seleção simultânea para PG e caracteres envolvidos com a capacidade adaptativa. As interações significativas de tratamentos $x$ épocas de semeadura para período reprodutivo (PR), IPG $\mathrm{I}_{(1)}, \mathrm{IPG}_{(2)}$ e teor de óleo (\%OL) evidenciam falta de correlação entre genótipos, o que dificulta a seleção baseada na média das épocas. Os efeitos diretos e indiretos de correlações confirmam a hipótese de que o início da floração e do desenvolvimento das vagens representam os principais estádios fisiológicos que determinam o potencial produtivo. As variâncias para capacidade geral de combinação e componentes de variância confirmam a hipótese de que os efeitos genéticos aditivos são predominantes, embora tenha sido detectada a existencia de efeitos epistáticos e de dominância. As distribuições alélicas mostram a contribuição de genes recessivos aumentando a expressão do número de dias para o florescimento (NDF) e \%OL (dominância unidirecional negativa), e de genes dominantes aumentando a expressão da $P G, I G_{(2)}$ e $P O$ (dominância unidirecional positiva). $O$ uso de parentais em função da capacidade de combinação e com o mesmo tipo de efeitos não aditivos, promovendo mudanças desejáveis na expressão fenotípica dos caracteres de interesse, é um importante auxílio na tarefa de maximizar os ganhos genéticos. No entanto, o uso de parentais exóticos deve preceder uma fase de prémelhoramento. 


\title{
GENETIC POTENTIAL OF SOYBEAN PARTIAL DIALLEL CROSSES WITH EMPHASIS ON SEED AND OIL YIELD
}

\author{
Author: Diego Omar Soldini
}

Adviser: Natal Antonio Vello

\section{SUMMARY}

Biological interpretations of environmental interactions effects, genetic correlations, genic actions, and allelic distributions, enable to increase success probabilities in obtaining individuals with favorable agronomic expressions. By using randomized complete-block design, 53 treatments were evaluated $\left(40 \mathrm{~F}_{2}\right.$ plant populations derived from partial diallel crossing $5 \times 8$, and 13 parents) in three periods inside the regular sowing season (November) in Piracicaba, State of São Paulo, Brazil $\left(22^{\circ} 42^{\prime} 30^{\prime \prime}\right.$ South latitude, $47^{\circ} 38^{\prime} 30^{\prime \prime}$ West longitude) in the crop season $1997 / 98$. The experimental plot was represented by 12 hill plots $0.8 \times 0.8 \mathrm{~m}$ apart, and in six replications in totality ( 2 replications $\times 3$ sowing periods) 72 plants were studied by treatment. The results showed that the increase in the oil yield (PO) depends on changes in the allelic frequency for grain yield (PG). Two grain yield indices (IPG ${ }_{(1)}$ and $\left.I P G_{(2)}\right)$ associated to the plant efficiency in time and vegetative development are useful as simultaneous selection criteria for PG and for characters related to adaptability. The significant interactions of treatments $x$ sowing period for reproductive period (PR), $I P G_{(1)}, I P G_{(2)}$ and the seed oil content (\%OL) show lack of correlation among genotypes, which makes the selection based on the mean of periods difficult. The direct and indirect effect of correlations confirm the hypothesis that the beginning of flowering and development of pods represent the main physiological stages that determine the yield potential. The variances for general combination abilities and the variances components confirm the hypothesis that the additive genetic effects are predominant, although the existance of epistatic and dominant effects have been found. The allelic distributions show recessive genes increasing the expression of number of days to flowering (NDF) and \%OL (negative unidirectional dominance), and dominant genes increasing the expression of $P G, I^{P} G_{(2)}$ and $P O$ (positive unidirectional dominance). The use of parents in terms of combining ability and with the same type of nonadditive effects that causes desirable changes in the phenotypic expression of characters of interest is an important help in the task of maximizing genetic gains. However, the use of exotic parents must preceed a pre-breeding phase. 


\section{INTRODUÇÃO}

O complexo grão-farelo-6leo da soja possui diversas aplicações entre as espécies oleaginosas. Como espécie oleífera, a soja é estudada geneticamente e seu comportamento modificado qualitativa e quantitativamente com a finalidade de otimizar a qualidade nutricional e tecnológica visando um melhor e mais amplo emprego industrial e alimentício. Ambos os tipos de modificações envolvem a introdução e recombinação de genes para alterar determinados componentes da semente em desenvolvimento. As modificações qualitativas têm como finalidade alterar a composição dos ácidos graxos e assim determinar usos específicos do bleo. Estas modificações exigem técniças, métodos e equipamentos para análises laboratoriais mais sofisticados, razão pela qual apenas recentemente os resultados obtidos em pesquisas básicas começaram a ser aplicados em programas de melhoramento genético.

As modificações quantitativas têm por finalidade mudar as proporções de 6leoproteína-carboidratos de armazenamento a partir de uma maior distribuição do carbono da sacarose favorecendo a síntese de óleo. Estas modificações quantitativas do óleo têm sido desenvolvidas principalmente a partir do emprego de métodos não destrutivos, rápidos e simples de análise do conteúdo químico da semente, possibilitando importantes avanços no conhecimento genético do teor de óleo e na aplicação de métodos de seleção mais eficientes em programas de melhoramento genético.

Como espécie produtora de grãos, a soja também é estudada geneticamente e sua produtividade modificada através da otimização quantitativa da produtividade de grãos per se e da otimização qualitativa de caracteres morfológicos associados com a adaptabilidade ambiental e agronômica. Ambos os tipos de modificações contribuíram 
significativamente para a expansão da cultura e o incremento da produção mundial de grãos.

Devido ao teor de 6́leo e a sua produtividade, a soja representa o mais importante recurso mundial de óleo comestivel; no entanto, têm ocorrido progressos pouco expressivos na quantidade de óleo ao longo da história do melhoramento. Como causa destaca-se, principalmente, a produtividade de grãos como único critério que determina o valor econômico para o produtor, levando assim a uma seleção preferencial para produtividade de grãos. A esta falta de premiação pelo maior conteúdo de óleo na comercialização dos grãos, soma-se a escassa disponibilidade e uso de germoplasma com alto teor de óleo e a falta de estudos genéticos.

Visando a incorporação de novos genes de interesse em genótipos cultivados, e com a finalidade de avaliar o potencial genético de genótipos adaptados e exóticos, com ênfase na produtividade de grãos e óleo, o trabalho tem como objetivos: estimar os efeitos da interação genótipos $x$ épocas de semeadura; estimar efeitos genéticos diretos e indiretos de correlações; determinar o tipo de ação gênica predominante envolvido na herança dos caracteres; e conhecer a distribuição das freqüências alélicas envolvida com os efeitos não aditivos, assim como a magnitude da sua expressão fenotípica.

O cumprimento desses objetivos deve colaborar, de forma científica e prática, na obtenção de germoplasma melhorado com propriedades adequadas às exigências de cultivo e de mercado. 


\section{REVISÃO DE LITERATURA}

\subsection{Projeções mundiais da produção e consumo de óleos vegetais}

As perspectivas da produção mundial de grãos das seis principais espécies oleaginosas: soja [Glycine max], girassol [Helianthus annuus], algodão [Gossypium herbaceum], amendoim [Arachis hypogaea], linho [Linum usitatissimum] e colza [Brassica napus] mostram a soja perfazendo cerca de $50 \%$ do total, com uma produção mundial estimada em 160 milhões de toneladas para o período 2008/12, superior em $35 \%$ a produção do período 1993/97 (Reunión Anual del Subprograma Soja, 1994).

Quanto à produção mundial de óleo, ainda que as projeções mostrem a soja com uma produção de 25 milhões de toneladas para o período 2008/12, superior em cerca de $43 \%$ à produção do período 1993/97, a maior produção de óleo de soja será superada a partir do período 1998/2002 pela óleo de dendê [Elaeis guineensis] com uma produção estimada em 30 milhões de toneladas para o período 2008/12. Embora essa inversão na maior produção de óleo estimule um incremento significativo no consumo de óleo de dendê, o óleo de soja manterá o nível atual de consumo, representando aproximadamente $19 \%$ do consumo mundial total de óleos vegetais e gorduras animais. Isso significará um volume de moagem de aproximadamente 138 milhões de toneladas, o que representará cerca de $50 \%$ do total de moagem de grãos para o período 2008/12 (Reunión Anual del Subprograma Soja, 1994).

Com respeito às projeções de aumento anual da demanda mundial de óleos vegetais e gorduras animais, há uma diminuição de $3 \%$ no período 1993/2002 para $2,5 \%$ no período $2003 / 08$. No entanto, o consumo médio per capita aumentará de 15,8 $\mathrm{kg} /$ ano no período 1993/97 para cerca de $18,5 \mathrm{~kg} /$ ano no período 2008/12. 
Atualmente, o aumento anual da demanda mundial de óleos vegetais representa um acréscimo de aproximadamente 1,5 milhões de $t$ /ano, o que corresponde a cerca de $40 \%$ e $30 \%$ da produção de óleo da Argentina e do Brasil, respectivamente (Reunión Anual del Subprograma Soja, 1994).

Análises do consumo mundial de óleos vegetais por regiões, considerando-se os atuais blocos econômicos, revelam um potencial de aumento na demanda (principalmente nos países asiáticos) e heterogeneidade regional no consumo. Assim, 0 consumo médio mundial de óleos vegetais e gorduras animais é de 15,8 kg/habitante/ano; no entanto, a exclusão das gorduras animais e das regiões de menor consumo de óleo (Europa Oriental, China, África e o subcontinente índico) permite elevar o consumo médio para $18 \mathrm{~kg} /$ habitante/ano, sendo na América Latina de $12,7 \mathrm{~kg} /$ habitante/ano. Considerando-se o consumo de óleo per capita, a soja participa com cerca de $3 \mathrm{~kg} /$ habitante/ano (Agromercados, 1995).

O consumo de óleo de soja em cada bloco econômico e região geográfica permite reconhecer ao bloco Nafta (Canadá, Estados Unidos e México) como consumidor preferencial de óleo de soja (60\% do total), seguido por América Latina (38\%), Japão (30\%) e China (22\%). Na Europa Oriental prefere-se o óleo de girassol, e na Malásia, Indonésia, África e América Latina, a gordura de dendê (Agromercados, 1995).

No caso do bloco econômico Mercosul, ainda que a Argentina seja o primeiro exportador mundial de óleo de soja, o consumo interno não supera $13 \%$, preferindo, junto com o Uruguai, o óleo de girassol. Já o Brasil é o grande consumidor de óleo de soja seguido pelo Paraguai. Considerando-se as médias mundiais, o óleo de soja é o de maior consumo, cobrindo cerca de $27 \%$ da demanda mundial de óleos vegetais, seguido pelo óleo de dendê com $24 \%$, o do complexo dendê $(23 \%)$, o de canola (15\%) e o de girassol (11\%) (Agromercados, 1995).

Sendo o teor de óleo um dos componentes químicos que determina junto com a produtividade de grãos os benefícios econômicos de exportadores e industriais, diversos modelos têm sido propostos e comparados (Apêndice A) para estimar o valor econômico da soja sobre a base do seu teor de óleo, proteína e produtividade (Leffel, 
1990). O uso destes modelos será importante nos programas de melhoramento, a fim de otimizar a seleção de cultivares com maior valor econômico.

\subsection{Biossínteses do óleo}

A semente em desenvolvimento está unida à placenta da vagem pelo funículo e, através do extremo chalazal do hilo, penetram os vasos condutores que levam a seiva às estruturas anatômicas. $O$ período entre a fertilização do óvulo prévio à antese e à maturação fisiológica caracteriza-se por um estágio inicial de rápidas divisões celulares nos cotilédones, que se completam em cerca de 15 dias após a fertilização. No segundo estágio, que se prolonga nos próximos 45 dias, ocorrem rápidas alongações celulares, elevadas atividades biossintéticas e um rápido incremento do peso seco da semente. Aproximadamente $50 \%$ do total de glicerolipídeos na semente madura é sintetizado entre 30 a 45 dias após a fertilização, ocorrendo uma rápida proliferação de vacúolos com óleo (Moore, 1993).

Embora o início do acúmulo de óleo na semente seja anterior ao da proteína, há uma inter-relação e/ou ligação entre a biossíntese de ambos os compostos, que deve ser considerada nas interpretações da correlação genética negativa entre teor óleo e teor de proteína. É provável que o fluxo de carbono ao óleo, ao carboidrato e à proteína esteja regulado durante o desenvolvimento da semente e que pelo menos parte deste controle esteja baseada num mecanismo de retroalimentação competitivo (Verma \& Shoemaker, 1996).

A relação entre os principais componentes químicos da semente de soja indica que, para um acréscimo de $1,00 \%$ no teor de óleo, ocorrem decréscimos de $1,44 \%$ no teor de proteína, $0,65 \%$ no teor de açúcares totais, e $1,00 \%$ no teor de polissacarídeo (Teixeira et al., 1984). Estes decréscimos correspondem a 1,50 e 0,50\%, nos teores de proteína e resíduos, respectivamente (Hanson, 1991 e Leffel \& Rhodes, 1993). Essas são variações esperadas no conteúdo de substâncias de reserva na semente de soja quando se direcionam os programas de melhoramento para a obtenção de maiores teores de óleo ou proteína, ou quando estes ocorrem por influência de condições ambientais. 
A principal forma de transporte do carbono para a síntese do oleo é a sacarose, cuja síntese está regulada principalmente pela sucrose fosfato sintetase e pela frutose-1,6bifosfatase (Cheikh \& Brenner, 1992). Na importação e conversão da sacarose em óleo participam numerosas enzimas, sendo a acetil-CoA carboxilase e a diacilglicerol acetil transferase a primeira e a última enzima da rota biossintética, respectivamente.

A biossíntese dos componentes do óleo durante o desenvolvimento da semente localiza-se, simultaneamente, nos plastídios e/ou cloroplastos e no retículo endoplasmático. Entre os dois compartimentos subcelulares há significativo intercâmbio de compostos lipídicos, e o retículo endoplasmático é o principal centro biossintético do citoplasma. Nos plastídios ocorre a síntese dos ácidos graxos palmítico, esteárico e oléico, através das enzimas transportadoras de acetil: beta-ketoacilsintetase I, beta-ketoacilsintetase II e delta-9 desaturase. Entretanto, no retículo endoplasmático, a síntese posterior dos ácidos graxos poliinsaturados linoléico e linolênico ocorre por dessaturação enzimática, a partir da liberação do ácido graxo oléico precursor ao citoplasma. As enzimas envolvidas nesta dessaturação oxigênio-dependente são as proteínas de membrana ômega-6 desaturase (oleate) e ômega-3 desaturase (linoleate) (Morre, 1993 e Verma \& Shoemaker, 1996).

A partir dos produtos de síntese plastidial e do retículo endoplasmático é finalmente sintetizado o triglicerol por ação da enzima diacilglicerol acetil transferase. $\mathrm{O}$ triglicerol acumula-se em organelas subcelulares "corpos de 6́leo", cuja estrutura e ontogenia dependem do depósito de triacilglicerol entre a dupla membrana do retículo endoplasmático com posterior liberação ao citoplasma como organelas com membrana.

$\mathrm{Na}$ composição do b́leo cru da semente de soja existem grupos heterogêneos de compostos e isômeros de lipídeos, dos quais os glicerolipídeos são os mais abundantes, destacando-se entre estes o triglicerol como o principal lipídeo de armazenamento na semente. Portanto, o óleo de soja é um triglicerol composto de ácidos graxos esterificados com moléculas de glicerol.

A composição lipídica varia de acordo com a fase de desenvolvimento da semente, e o conteúdo e composição final do óleo na semente madura depende, principalmente, do balanço de atividades multienzimáticas, da duração do período de 
desenvolvimento e da influência da temperatura (Browse \& Somerville, 1991; Kinney, 1994 e Murphy, 1995). Maiores detalhes sobre o metabolismo dos lipídeos em plantas podem ser encontrados em Moore (1993).

\subsection{Contribuições à genética e melhoramento do teor de óleo}

A variação do conteúdo e composição de óleo nas sementes $F_{2: 1}$ apresenta componentes ambientais representados por variações entre plantas, entre vagens (por efeito de posição na planta) e entre sementes na vagem (Miranda et al., 1984). No caso da composição, os componentes genéticos da variação estão representados pelos efeitos do genoma nuclear materno e/ou do genoma nuclear da semente, dependendo da linhagem mutante e do ácido graxo específico (Erickson et al., 1988 e Graef et al., 1985). No caso do conteúdo, estes componentes são representados pelo efeito do genoma nuclear materno (Miranda et al., 1984 e Sing \& Hadley, 1968); portanto, a herdabilidade das diferenças no conteúdo entre sementes $F_{2: 1}$ são pouco consistentes. Embora parte da síntese de óleo ocorra em compartimentos cloroplastidiais com seu próprio genoma, não há evidências de herança citoplasmática.

A seleção recorrente massal e de famílias de meio-irmãos têm permitido significativos progressos na modificação do conteúdo e composição do óleo (Burton \& Brim, 1981 e Burton et al., 1983). No entanto, ao contrário do conteúdo de proteína, escassa quantidade (Wilcox, 1985) e ausência (Guangyu et al., 1993 e Zhihong et al., 1989) de germoplasma com alto conteúdo de óleo em formas silvestres de G. max e em G. soja têm limitado significativamente o potencial de melhoramento. A mutagênese tem provocado incrementos de variabilidade genética para conteúdo de óleo e mudanças nas correlações do teor de óleo com outros caracteres (Mehetre et al., 1996).

\subsection{Produtividade de grãos}

Ao longo do desenvolvimento do melhoramento genético de soja, a produtividade de grãos per se tem sido uns dos mais importantes objetivos de seleção cíclica, na qual cultivares superiores liberados são recombinados e suas progênies superiores novamente liberadas para o cultivo comercial. A história deste processo 
recorrente de modificações genéticas quantitativas, associadas a uma melhoria nas condições ambientais de cultivo, tem proporcionado ganhos genéticos significativos.

O estudo de 240 cultivares liberados nos Estados Unidos entre 1924/80 determinou que o ganho genético anual médio para produtividade foi de: 19,1; 17,4; 13,$8 ; 29,1 ; 17,2 ; 22,5 \mathrm{Kg} / \mathrm{ha}^{-1}$ para os grupos de maturidade 00,0 , I, II, III, IV e V, respectivamente (Specht \& Graef, 1996); já Prescott-Allen (1988) estimou um ganho genético de $112 \%$ em média, entre 1930/75.

Uma conseqüência negativa deste ganho genético contínuo tem sido a redução significativa da base genética do germoplasma cultivado. Análises das genealogias de 258 cultivares públicos liberados nos Estados Unidos entre 1947/88 indicam que os cultivares obtidos depois de 1983 têm $50 \%$ mais genes em comum que os obtidos antes de 1954 (Gizlice et al., 1993). No entanto, esta redução da diversidade genética no germoplasma não compromete nem limita futuros ganhos genéticos, já que mecanismos tais como amplificação gênica, elementos transponíveis, interações alélicas e epistasia somados à recombinação geram constantemente nova diversidade genética no germoplasma "elite" empregado nos programas de melhoramento (Rasmusson \& Phillips, 1997).

Ainda que os avanços genéticos obtidos e os atuais potenciais de produtividade sejam resultado da acumulação progressiva de poligenes, a otimização de caracteres morfológicos e fisiológicos determinantes da adaptabilidade ambiental e agronômica dos genótipos tem sido decisiva para que estes potenciais genéticos de produtividade de grãos per se sejam expressos fenotipicamente.

Assim, destacam-se como caracteres importantes o número de dias para o florescimento e para a maturidade, e a altura da planta na maturidade, responsáveis pela capacidade de crescimento vegetativo (biomassa), adaptação ao fotoperíodo da estação de crescimento e disponibilidade de nós e gemas reprodutivas.

Um dos principais problemas da seleção simultânea para estes caracteres morfo-fisiológicos e para alta produtividade per se, é a freqüente correlação genética positiva (Freire Filho 1988; Montaño-Velasco, 1994 e Soldini, 1993; entre outros), a qual leva a obter máximas produtividades em genótipos com grande produção de biomassa 
(ciclo longo e altura excessiva). Isto ocasiona dificuldades de ordem agronômica, além do alto risco do cultivo, pela demora na colheita. Dificuldades como acamamento e maior incidência e severidade de doenças estão associadas a estas correlações.

A seleção exclusiva para produtividade de grãos em autógamas aumenta o índice de colheita (produtividade / biomassa) com escasso ou nenhum aumento de biomassa; no entanto, sugere-se que para se obter o melhoramento da produtividade, associado com a eficiência fisiológica da planta, é necessária a seleção simultânea para três componentes principais da produtividade: proporção maior de biomassa acumulada, maior índice de colheita e ciclo biológico (Wallace et al.,1993). Os maiores índices de colheita são obtidos em genótipos precoces; enquanto que as maiores produtividade de grãos são verificadas nos genótipos de ciclo normal (Billore \& Joshi, 1997).

A eficiência, do ponto de vista agronômico, é medida pelo índice de colheita que estima a distribuição de grãos / biomassa na planta. Devido ao fato deste índice ser de difícil e demorada avaliação, inviabiliza o seu emprego em programas de melhoramento. Assim, uma alternativa que pode ser empregada é o cálculo da eficiência da planta a partir do acúmulo da produtividade de grãos em relação ao período reprodutivo e à altura da planta. Sendo assim, a construção destes índices pode auxiliar no melhoramento .

\subsection{Ações gênicas, correlações e interações genótipos $x$ ambientes}

O desenvolvimento e aplicação de modelos genético-estatísticos e a decomposição de parâmetros tais como médias, variâncias e covariâncias a partir de uma tabela dialélica têm sido a principal estratégia para o conhecimento do tipo de ação gênica que controla a expressão fenotípica dos principais caracteres quantitativos de importância agronômica e comercial em espécies autógamas (Bonato, 1989; Burton, 1987; Freire Filho, 1988 e Viana, 1994, entre outros). Assim, os ganhos genéticos obtidos (Prescott-Allen, 1988 e Specht \& Graef, 1996) são resultados principalmente da predominância da ação gênica aditiva e da epistasia aditiva $x$ aditiva somadas ao melhoramento das condições ambientais de cultivo. Atualmente, a transformação 
genética e o mapeamento do genoma baseado em marcadores moleculares somam-se como estratégias para o aproveitamento mais eficiente da variabilidade genética em programas de melhoramento, exploração de efeitos epistáticos e identificacão de marcadores associados aos QTL (Quantitative Traits Loci) de efeitos pronunciados (Ferreira \& Grattapaglia, 1995; Lark, et al., 1995; Handel et al., 1996 e Verma \& Shoemaker, 1996, entre outros).

Além da ação gênica aditiva, aspectos tais como o conhecimento do sinal e magnitude das correlações genéticas (Bhatia et al., 1997; Mehetre et al., 1994 e Taware et al., 1997) e natureza das interações envolvendo diferentes ambientes (Cruz \& Regazzi, 1997; Gauch \& Zobel, 1996 e Mariotti, 1994) têm sido decisivos no incremento da produtividade. 


\section{MATERIAL E MÉTODOS}

\subsection{Material genético}

A partir das informações disponíveis na base de dados do Programa de Melhoramento de Soja do Departamento de Genética da Escola Superior de Agricultura "Luiz de Queiroz", Universidade de São Paulo (ESALQ/USP), e de acordo com os objetivos de alto teor e produtividade de óleo, performance agronômica e fitossanidade, foram selecionados 13 parentais $(\mathrm{I}+\mathrm{J}=\mathrm{N})$ divididos em dois grupos: grupo 1 (G1) com I = 5 genótipos e grupo 2 (G2) com J = 8 genótipos. Os dois grupos foram combinados de acordo com o delineamento genético de cruzamentos dialélicos parciais $(\mathrm{I} \times \mathrm{J})$. Esse delineamento comparado ao dialelo completo reduz o número de combinações híbridas de [N (N - 1) / 2] para [I x J] ao evitar cruzamentos sem interesse de avaliação.

Os parentais foram representados por nove linhagens experimentais adaptadas, com sigla USP (Vello et al., 1994; Hiromoto, 1996) de alta produtividade de óleo, obtidas no primeiro ciclo de seleção recorrente, desenvolvidas pelo Setor de Genética Aplicada às Espécies Autógamas, Departamento de Genética , ESALQ/USP; por dois cultivares exóticos: Lamar (Hartwig et al. 1990) e Hartwig (Anand, 1992); e por duas novas introduções: PI 181.544 e PI 371.611 da EMBRAPA - Centro Nacional de Pesquisa de Soja - CNPSo / Londrina, PR. Detalhes sobre as genealogias e características dos parentais são apresentados no Apêndice B1.

No ano agrícola 1996/97 foram feitos os cruzamentos planta-a-planta em telado, utilizando-se a técnica de múltiplas (8-10) datas de semeadura para coincidir o florescimento e incrementar o período de floração. Parentais com marcadores 
fenotípicos recessivos (flor branca e pubescência cinza) foram empregados de preferência como fêmeas para facilitar e antecipar a confirmação dos híbridos $F_{1}$.

A semeadura dos parentais para os cruzamentos foi realizada em vasos de cerâmica com uma mistura de três partes de terra e uma parte de adubo orgânico e, após a germinação, foi feito o desbaste deixando duas plantas por vaso. A cada 15 dias foi feita uma poda dos ramos para evitar o estiolamento das plantas, devido à menor intensidade de luz solar e ao excessivo crescimento vegetativo de alguns genótipos de hábito de crescimento determinado, que em tais condições comportam-se como os de crescimento indeterminado. Esta técnica, além de permitir o controle do crescimento, reduzindo os entrenós, facilita o manejo e os cruzamentos, e prolonga o período de floração das plantas em telado, complementando a técnica de múltiplas datas de semeadura na disponibilidade de um maior número e melhor localização de flores para os cruzamentos.

No inverno de 1997 foi realizado o avanço da geração $F_{1}$ e multiplicação dos genótipos parentais em condições de campo. As sementes foram germinadas em condições de laboratório e após quatro dias transferidas para copos de plástico com terra de alta fertilidade. Após oito dias da transfêrencia, as plantas foram transplantadas no campo em covas individuais espaçadas de 0,5 x 1,0 m. Foram utilizados os marcadores fenotípicos: cor do hipocotilo, da flor e da pubescência, para confirmar os cruzamentos envolvendo parentais empregados como fêmea com marcadores recessivos, e macho com dominantes. Os cruzamentos restantes foram confirmados em $\mathrm{F}_{2}$.

A partir de dados coletados de plantas individuais foram avaliados os seguintes caracteres:

NDF: Número de dias para o florescimento, contados a partir da data de semeadura até a data do início do florescimento (Estádio $R_{1}$ da escala de Fehr \& Cavinnes, 1977);

NDM: Número de dias para a maturidade, contados a partir da data de semeadura até a data em que $50 \%$ da planta apresenta $95 \%$ das vagens maduras (Estádio $R_{8}$ da escala de Fehr \& Cavinnes, 1977); 
PR: Período reprodutivo (dias) avaliado pelo número de dias a partir do início do florescimento $\left(R_{1}\right)$ até a maturidade da planta $\left(R_{8}\right)$;

APM: Altura da planta na maturidade $(\mathrm{cm})$, avaliada como a distancia entre a base da planta (solo) e o ápice da haste principal da planta madura;

PG: Produtividade de grãos por planta (g/planta) com umidade ajustada para $13 \%$;

IPG $_{(1)}$ : Índice de produtividade 1; produtividade de grãos por planta, por dia, (g/planta/dia) durante o PR (IPG $(1)=P G / P R)$;

IPG $_{(2):}$ Índice de produtividade 2; produtividade de grãos por planta, por centímetro de altura da haste principal $(\mathrm{g} / \mathrm{planta} / \mathrm{cm})$ no período entre a semeadura $\mathrm{e}$ a maturidade $\left(\mathrm{IPG}_{(2)}=\mathrm{PG} / \mathrm{APM}\right)$;

\%OL: Porcentagem de óleo na semente da geração $F_{3: 2}$ (sementes $F_{3}$ refletem o genótipo da planta mãe $F_{2}$ ). A avaliação foi feita no Centro Nacional de Pesquisa e Desenvolvimento de Instrumentação Agropecuária da EMBRAPA, pela metodologia não-destrutiva de espectrometria de ressonância nuclear magnética (NMR), utilizandose o aparelho de NMR desenvolvido pela EMBRAPA-CNPDIA, São Carlos, (Apêndice C);

PO: Produtividade de óleo por planta ( $\mathrm{g} /$ planta) obtida pelo produto entre a produtividade de grãos (PG) e o porcentagem de óleo na semente (\%OL), dividido por 100.

A fim de estudar novos caracteres que possam servir de estimadores da capacidade produtiva e que sejam de fácil e rápida avaliação em programas de melhoramento, além da própria produtividade de grãos per se, foram construídos dois índices de produtividade: $\mathrm{IPG}_{(1)}$ e $\mathrm{IPG}_{(2)}$. Ambos os índices avaliam a eficiência produtiva da planta em termos de tempo (dias) e crescimento (cm).

\subsection{Procedimento experimental}

Os 53 tratamentos ( $5 \times 8=40$ populações $F_{2}$ e 13 parentais) foram avaliados em delineamento experimental de blocos completos ao acaso com duas repetições, na área experimental do Departamento de Genética da ESALQ/USP, Piracicaba, São Paulo, 
situada a $22^{\circ} 42^{\prime} 30^{\prime \prime}$ de latitude Sul, $47^{\circ} 38^{\prime} 30^{\prime \prime}$ de longitude Oeste e a uma altitude de $546 \mathrm{~m}$ acima do nível do mar. Os experimentos foram conducidos em três épocas diferentes dentro do período normal de semeadura: $E_{1}$ (28/10/97); $E_{2}(12 / 11 / 97) ; E_{3}$ (26/11/97); a parcela experimental foi representada por 12 covas de plantas individuais espaçadas de $0,8 \times 0,8 \mathrm{~m}$, totalizando uma área útil de $7,68 \mathrm{~m}^{2}$. No total de seis repetições ( 2 repetições $\times 3$ épocas de semeadura), foram pesquisadas 72 plantas por tratamento.

\subsection{Análises estatísticas}

\subsubsection{Análises de variância individuais e conjuntas}

Para cada época de semeadura (E) foram feitas análises de variância individuais, com desdobramento da soma de quadrados de tratamentos $(\mathrm{T})$, associada $a(p+q+p q-1)$ graus de liberdade, em somas de quadrados de parentais $(P)$ e de cruzamentos $(\mathrm{Cr})$, associadas a $(\mathrm{p}+\mathrm{q}-1)$ e $(\mathrm{pq}-1)$ graus de liberdade. Há também um grau de liberdade adicional que testa o contraste $P$ vs $C r$. Com a finalidade de proporcionar uma maior precisão nas análises, os $\mathrm{P} \mathrm{e} \mathrm{Cr}$ foram agrupados em ciclos de maturidade $\left(\mathrm{C}^{\mathrm{P}}\right.$ e $\left.\mathrm{C} \mathrm{Cr}\right)$ de acordo com o número médio de dias para a maturidade (NMDM), com intervalo máximo de cinco dias, e realizados os desdobramentos das somas de quadrados correspondentes em soma de quadrados de $C^{P}, P / C^{P}, C^{C r}$ e $\mathrm{Cr} / \mathrm{Cr}$.

Com a finalidade de analisar os efeitos de $\mathrm{T} \times \mathrm{E}$ foram feitas análises de variância conjuntas com desdobramento da soma de quadrados da interação associada $a(p+q+p q-1) \times(e-1)$ graus de liberdade, em soma de quadrados de P $\times$ E e Cr $\times E$, associadas $a(p+q-1) \times(e-1) e(p q-1) \times(e-1)$. Por sua vez, as somas de quadrados $P$ $x \mathrm{E}$ e $\mathrm{Cr} \times \mathrm{E}$ foram desdobradas em somas de quadrados de $\mathrm{CP} \times \mathrm{E}, \mathrm{P} \times \mathrm{E} / \mathrm{CP}, \mathrm{C} r \times \mathrm{E}$, $\mathrm{Cr} \times \mathrm{E} / \mathrm{CCr}, \mathrm{e}(\mathrm{P}$ vs $\mathrm{Cr}) \times \mathrm{E}$.

- Modelo matemático de análise de variância individual:

$Y_{i j}=u+t_{i}+b_{j}+e_{i j}$ 
- Modelo matemático de análise de variância conjunta:

$Y_{\text {irs }}=u+t_{i}+s_{k}+(t \times s)_{i k}+(b / s)_{j: k}+\bar{e}_{i j: k}$

onde:

$\mathrm{i}=1,2, \ldots, \mathrm{T} \quad(\mathrm{T}=$ número de tratamentos $)$;

$\mathrm{j}=1,2, \ldots$, B (B número de blocos);

$k=1,2,3 \quad(S=$ número de épocas de semeadura);

$Y_{\text {ir }}$ e $Y_{\text {irs }}$ : valor observado na unidade experimental;

$u$ : $\quad$ média geral do experimento;

$t_{i}: \quad$ efeito do tratamento $\mathbf{i}$;

$b_{j}$ e (b/s) j:k : efeito do bloco $\mathbf{j}$ e do bloco $\mathbf{j}$ dentro de época de semeadura $k$;

$(t \times s)_{\text {is }}$ : efeito da interação do tratamento i com a época de semeadura $k$;

$e_{i j}$ e $\bar{e}_{i j: k}: \quad$ erro experimental e erro experimental médio.

De acordo com Cruz \& Castoldi (1991) foi realizado o desdobramento do quadrado médio da interação $\mathrm{T}$ x pares de $\mathrm{E}$ em porcentagem da parte simples (\%PS) e porcentagem da parte complexa (\%PC); e de acordo com Cruz \& Regazzi (1997), a estratificação de E. Este agrupamento consiste em estimar a soma de quadrados para a interação entre genótipos e pares de $\mathrm{E}$ e, posteriormente, agrupar aquelas $\mathrm{E}$ cuja interação seja não significativa (Apêndices D1 e D2).

\subsubsection{Análises de correlações parciais}

Com base em Cruz \& Castoldi (1991) foi feita a decomposição do coeficiente de correlação genética ( $\mathrm{rg}$ ) através da análise de caminhamento (trilha), a fim de se estimarem os efeitos genéticos diretos (EGD) e indiretos (EGI) de grupos de caracteres explicativos sobre um determinado caráter principal. Para esta análise os dados dos caracteres NDF, NDM, PR, APM, PG e \%OL foram transformados por $\log _{10}(x)$ e IPG I(1) $_{\text {, }}$ $\mathrm{IPG}_{(2)}$ e PO por $\log _{10}(x+1)$, a fim de eliminar qualquer efeito multiplicativo na escala original dos dados. As equações de cálculo são apresentadas no Apêndice D3.

\subsubsection{Análises dialélicas}


Foram aplicados os seguintes modelos dialélicos cujas considerações são apresentadas a seguir.

a) Modelo 1, Método 4 de Griffing (1956), adaptado para dialelos parciais por Geraldi \& Miranda-Filho (1988). O modelo estuda a capacidade de combinação a partir do desdobramento da soma de quadrados de tratamentos $(T)$ associada a $(p+q+p q-$ 1) graus de liberdade, em soma de quadrados de parentais $(P)$ e cruzamentos $(\mathrm{Cr})$, associadas a $(p+q-1)$ e $(p q-1)$ graus de liberdade. Posteriormente, desdobra-se a soma de quadrados de $\mathrm{Cr}$ em somas de quadrados dos efeitos da capacidade geral de combinação (CGC) para o G1 e G2, e específica (CEC) associadas a (p - 1), (q - 1) e (pq 1) graus de liberdade, respectivamente. Os estimadores dos efeitos com seus respectivos desvios são apresentados no Apêndice D4.

- Modelo estatístico-genético:

$Y_{i j}=u+g_{i}+g_{j}+s_{i j}+\bar{e}_{i j}$

onde:

$\mathrm{i}=1,2, \ldots, \mathrm{p} \quad(\mathrm{p}=$ número de parentais do grupo 1$) ;$

$j=1,2, \ldots, q \quad(q=$ número de parentais do grupo 2);

$Y_{\mathrm{ij}}$ : $\quad$ média do cruzamento envolvendo o parental $\mathbf{i}$ do grupo 1 e o parental $\mathbf{j}$ do grupo 2;

u: $\quad$ média geral do dialelo;

$g_{i:} \quad$ efeito da capacidade geral de combinação do parental i do grupo 1;

8j: $\quad$ efeito da capacidade geral de combinação do parental j do grupo 2;

$g_{i j:} \quad$ efeito da capacidade específica de combinação resultante do cruzamento entre parentais $\mathbf{i}$ do grupo 1 e j do grupo 2;

$\overline{\mathbf{e}}_{\mathrm{ij}}: \quad$ erro experimental médio.

b) Modelo de Gardner \& Eberhart (1966), adaptado para dialelos parciais por Miranda-Filho \& Geraldi (1984). Foi usado o modelo reduzido que estuda o efeito de grupos G1 e G2 e G1 vs G2, associados a (p - 1), (q - 1) e 1 graus de liberdade, respectivamente, a partir do desdobramento da soma de quadrados de $T$. Os estimadores dos efeitos com seus respectivos desvios se encontram no Apêndice D5. 
- Modelo estatístico-genético:

$Y_{i j}=u+1 / 2\left(v_{i}+v_{j}\right)+\bar{e}_{i j}$

onde:

$i=1,2, \ldots, p \quad(p=$ número de parentais do grupo 1$) ;$

$j=1,2, \ldots, q \quad(q=$ número de parentais do grupo 2$) ;$

$u$ : $\quad$ constante associada ao modelo;

$v_{i}$ : $\quad$ efeito do parental i do grupo 1;

$v_{j}$ : $\quad$ efeito do parental $\mathbf{j}$ do grupo 2;

Relacionando ambos os modelos dialélicos para efeitos fixos e emprego de híbridos $F_{1}$, as estimativas da CGC $(g i$, gj) do Método 4 de Griffing (1956) equivalem a $\left[1 \frac{1}{2} v i+h i\right]$ e $[1 / 2 v j+h j]$ no modelo de Gardner \& Eberhart (1966). Segundo MirandaFilho \& Chaves (1996), quando são empregadas gerações $F_{2}$, tal equivalência não é correta, já que as estimativas da CGC $\left(g i^{*}\right.$ e $\left.g j^{*}\right)$ correspondem a $\left[g i^{*}=1 / 2 v i+1 / 2 h i\right]$ e $\left[g j^{*}=1 / 2 v j+1 / 2 h j\right]$.

c) Modelo de Hayman (1954), adaptado para dialelos parciais com uso de geração $F_{2}$ por Viana (1994). Esta metodologia não se baseia em modelos estatísticos previamente estabelecidos, mas no conhecimento da natureza ambiental e genética de estatísticas, tais como médias, variâncias e covariâncias, obtidas a partir de uma tabela dialélica. Os dados de todos os caracteres na escala original, com exceção de \%OL, foram transformados por $\log (x+1)$ a fim de obter a suficiência do modelo aditivodominante através do teste baseado na análise de regressão linear $\left(\mathrm{H}_{0}: b=1\right)$ das covariâncias $\left(W_{1}, W_{2}\right)$ em função das variâncias $\left(V_{1}, V_{2}\right)$, respectivamente em G1 e G2. Quando a transformação logarítmica não foi apropriada para obter suficiência do modelo, procedeu-se à eliminação de parentais do esquema dialélico: $(\mathrm{I}-1) \times(\mathrm{J}-1)$ para NDM e PR e (I - 2) x (J - 2) para APM. Igualmente procedeu-se para \%OL (I - 2) $x$ $(J-2)$ com os dados originais. Detalhes sobre o teste de suficiência, componentes e parâmetros genéticos são mostrados no Apêndice D6 e Figuras B e C.

A metodologia permite estimar componentes genéticos de variação, devidos aos efeitos aditivos (D), dominantes (H1 e $\mathrm{H2}$ ) e covariância entre efeitos aditivos e dominantes (F); além de parâmetros genéticos, tais como: distribuição dos alelos entre 
os parentais (simetria), grau médio de dominância (gmd), proporção de genes dominantes e recessivos $(d / r)$, direção de dominância (dd) e herdabilidade $\left(h_{a}^{2} e^{2}{ }_{r}^{2}\right)$.

Os dados de médias de parcelas e de repetições correspondentes aos caracteres avaliados foram submetidos às análises estatísticas de acordo com as metodologias e modelos citados, com o auxílio do programa SAS ${ }^{\circledR}$ (Statistical Analysis System, 1996), e do programa GENES ${ }^{\circledR}$ (Universidade Federal de Viçosa, 1997). 


\section{RESULTADOS E DISCUSSÃO}

\subsection{Análises de variância individuais}

As análises de variância individuais para cada época de semeadura (E) com desdobramento de tratamentos $(\mathrm{T})$ em efeitos de parentais $(\mathrm{P})$ e cruzamentos $(\mathrm{Cr})$, e destes dois últimos, considerando o agrupamento em ciclos de maturidade $(\mathrm{C}, \mathrm{C}$ r, $\mathrm{P} / \mathrm{CP}^{\mathrm{P}}$ e $\mathrm{Cr} / \mathrm{CCr}$ ), são apresentadas nas Tabelas 1 a 3. $\mathrm{O}$ primeiro desdobramento mostrou efeitos significativos ( $p<0,05$ e $p<0,01$ ) dos quadrados médios de parentais e cruzamentos para todos os caracteres nas três $\mathrm{E}$ e, pela magnitude dos valores do teste $\mathrm{F}$; a \%OL $(2,3 \leq \mathrm{F} \leq 7,3)$ foi o caráter que exibiu menor variabilidade, enquanto que o NDF (15 $\leq \mathrm{F} \leq 413)$ apresentou maior variabilidade. Apesar desta baixa variabilidade para \%OL, foi demonstrada a existência de um marcador molecular (A715) explicando 7,0\% da variação em indivíduos $F_{2: 3}$ (Qiu et al., 1997); em termos de genótipos adaptados, isto representa um acréscimo de 1,47\%, considerando-se o teor médio de $21,0 \%$. Embora seja difícil distinguir entre efeitos pleiotrópicos e genes em aglomerado (Doubler et al., 1997), a identificação de "fatores" principais (Brummer et al., 1997 e Lee et al., 1996) e a seleção assistida, demonstram que os caracteres poligênicos podem ser parcialmente tratados como qualitativos para fins de melhoramento. Uma característica quantitativa não é necessariamente uma característica quantitativamente herdável (Gai \& You, 1994).

Para os outros caracteres, a magnitude dos valores do teste $F$ variou de 3,9 a 119. Os efeitos $P$ vs $C r$ evidenciaram diferenças significativas $(p<0,01)$ dos quadrados médios para NDF e NDM nas três $E$, e para $P R$ e $\mathrm{IPG}_{(2)}$ na $E_{1}$ com valores do teste $F$ variando de 11 a 394.

Em geral foi observado que há associação entre PG e PO no que diz respeito à magnitude e significância dos valores do teste $\mathrm{F}$, não ocorrendo o mesmo entre \%OL e 
PO, fato este que explica a importância da variabilidade para PG sobre a variabilidade para PO. Com a finalidade de superar esta falta de contribuição da \%OL à PO, o peso de 100 sementes pode representar uma estratégia alternativa. Assim, a seleção de genótipos com tamanho de sementes menor que a média e o peso médio de 100 sementes maior que a média pode favorecer o aumento da PO. As baixas PG de genótipos com alta porcentagem de proteína em relação aos genótipos de porcentagem normal e aos de alta \%OL estão associadas, principalmente, às diferenças de densidade dos grãos (Hatwig \& Collins, 1962). A seleção a favor do peso de 100 sementes, associada ao tamanho da semente menor que a média ou normal, pode favorecer a redução das correlações genéticas negativas entre peso de $\mathbf{1 0 0}$ sementes e número de sementes/planta (Taware et al., 1997), provocadas, principalmente, pelo aumento do tamanho das sementes. Embora as correlações ao nível de plantas individuais mostrem as verdadeiras relações biológicas entre os caracteres, é importante salientar que as magnitudes e/ou sinal das mesmas podem não refletir as verdadeiras relações dos caracteres em condições normais de cultivo com alta densidade e competitividade.

Outras associações desta natureza foram observadas entre PG e IPG $\mathrm{Il}_{(1)}$ e, em menor proporção, entre PG e IPG $(2)$. Isto mostra que a variabilidade para PG também explica a existencia de variabilidade para ambos os índices de produtividade associados à eficiência produtiva da planta em termos de tempo (dias) e crescimento (cm). A ordenação decrescente dos $\mathrm{T}$ em função destes estimadores pode auxiliar na seleção simultânea para PG e para caracteres morfo-fisiológicos (NDF, NDM e APM) ao individualizar genótipos com associação menor ou nula de alta PG com ciclo longo e/ou excessiva produção de biomassa. Assim, a variabilidade para estes índices da eficiência fisiologica da planta pode facilitar e agilizar a avaliação de genótipos em programas de melhoramento.

O segundo desdobramento mostrou efeitos significativos $(p<0,05$ e $p<0,01)$ dos quadrados médios de $\mathrm{C}^{\mathrm{P}}$ e $\mathrm{CCr}^{\mathrm{C}}$ para todos os caracteres nas três $\mathrm{E}$, exceto de $\mathrm{C}^{\mathrm{P}}$ para \%OL na $E_{1}$. Pela magnitude dos valores do teste $F$, verificou-se novamente que a $\%$ OL $(0,6 \leq F \leq 32)$ e o NDF (75 $\leq F \leq 2372)$ foram os caracteres que apresentaram menor e maior variabilidade, respectivamente. Observa-se também que o aumento 
progressivo dos quadrados médios de CCr para $P G$, IPG $(1), I_{(2)}$, \%OL e PO da $E_{3}$ para a $E_{1}$ ocorreu de forma inversa ao aumento das médias (Tabelas 6 a 8). Assim, a $E_{3}$ representa o ambiente com menor variabilidade e médias máximas. Esta é uma combinação comum de parâmetros, porém não desejada pelos melhoristas no momento da seleção. No entanto, desde que o ambiente tenha capacidade de discriminação e de predizer o comportamento dos genótipos na área mais provável de difusão, pode ser empregado como ambiente de seleção (Mariotti, 1994).

Para os efeitos de $\mathrm{P} / \mathrm{C}^{\mathrm{P}}$ destacou-se a não significância $(\mathrm{p}<0,05)$ dos quadrados médios de $\mathrm{P} / \mathrm{CP}^{\mathrm{P}}$ para todos os caracteres na $\mathrm{E}_{1}$. Este ciclo inclui os quatro parentais exóticos e mais precoces; portanto, a falta de variabilidade para todos os caracteres dentro de ciclo é explicada principalmente pelo estresse hídrico e pelas altas temperaturas ocorridas em janeiro pela presença de um veranico (Apêndice B2), que atingiu especialmente os genótipos de ciclo mais curto na fase de granação ou enchimento de grãos. Já para os efeitos de $P / C^{P} .3$ foi observada significância $(p<0,05$ e $p<0,01)$ dos quadrados médios para todos os caracteres na $E_{1}$ e $E_{2} . \mathrm{Na}_{3}$ foi destacada a significância $(p<0,01)$ dos quadrados médios dos três ciclos de parentais para NDM, PR e APM.

Para os efeitos de $\mathrm{Cr} / \mathrm{Cr}$ na $\mathrm{E}_{1}$ destacaram-se as significâncias $(\mathrm{p}<0,05 \mathrm{e} \mathrm{p}<$ 0,01) dos quadrados médios de $\mathrm{Cr} / \mathrm{Cr} .3$ ao $\mathrm{Cr} / \mathrm{Cr} .6$ para NDF, PG, $\mathrm{IPG}_{(1)}$ e PO; e dos quadrados médios de $\mathrm{Cr} / \mathrm{C} \mathrm{Cr} .1$ e $\mathrm{Cr} / \mathrm{Ccr} .2$ para \%OL. $\mathrm{Na} \mathrm{E}_{2}$, foram observadas significâncias $(\mathrm{p}<0,01)$ dos quadrados médios de $\mathrm{Cr} / \mathrm{C}$ r.1 ao $\mathrm{Cr} / \mathrm{C}$ r.7 para NDF; e de $\mathrm{Cr} / \mathrm{CCr} .5$ para APM, PG, IPG $\mathrm{I}_{(1)}, \mathrm{IPG}_{(2)}$ e PO. $\mathrm{Na} \mathrm{E}_{3}$, destaram-se as significâncias ( $\mathrm{p}<$ $0,05$ e $\mathrm{p}<0,01)$ dos quadrados médios de $\mathrm{Cr} / \mathrm{CCr} .2$ ao $\mathrm{Cr} / \mathrm{C}$ r.6 para PR, APM e IPG $(1)$.

Este desdobramento em ciclos de maturidade detectou grupos ( $\mathrm{Cr} / \mathrm{Cr} .3$ na $\mathrm{E}_{1}$,

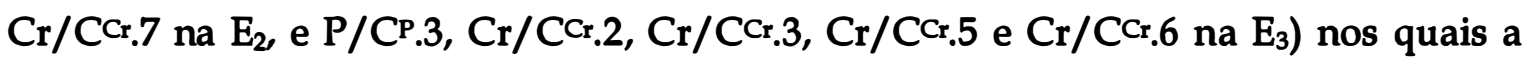
não-significância $(p<0,05)$ para PG está associada à significância $(p<0,01)$, principalmente para $\mathrm{IPG}_{(2)}$. Isto demonstra que os índices de eficiência fisiológica da planta podem ser empregados como critérios principais de seleção. Quando não há diferenças em PG, a seleção para máximos índices permite individualizar os genótipos de melhor desempenho, maior precocidade e menor altura de planta. Foi observado 
também que os efeitos de $\mathrm{Cr} / \mathrm{C} C r$ foram não-significativos $(\mathrm{p}<0,05)$ para NDM nas três $\mathrm{E}$, fato este explicado pelo agrupamento dos $\mathrm{T}$, com diferenças máximas de 5 dias em ciclos de maturidade, de acordo com o NMDM.

Os resultados mostram que o desdobramento dos $\mathrm{T}$ reduz a magnitude dos valores do teste $\mathrm{F}$ para todos os caracteres, indicando a importância de se avaliar conjuntos de genótipos similares em ciclos de maturidade a fim de não superestimar a verdadeira variabilidade dos outros caracteres. Isto permite avaliar com maior precisão e individualizar aqueles grupos de genótipos com disponibilidade de variabilidade genética de importância agronômica.

Pela magnitude dos valores do teste $\mathrm{F}$ correspondentes a parentais $\mathrm{e}$ cruzamentos, os caracteres podem ser ordenados de forma decrescente da seguinte maneira: NDF, NDM e APM como os de maior variabilidade, e $\mathrm{IPG}_{(2)}$ e \%OL como os de menor variabilidade. Assim, apesar da inclusão dos materiais exóticos de alto \%OL: PI 181.544 e PI 371.611 (Germplasm Resources Information Network, 1998) ao nível de médias de parcelas, o caráter não mostra variabilidade de importância agronômica. Já para as observações individuais nas três $\mathrm{E}$ observou-se que $11 \%$ das plantas dos 10 cruzamentos envolvendo ambos os parentais, e $13 \%$ das plantas dos parentais, estão incluídas no quartil $3(75 \%)$ para \%OL e, portanto, são superiores a $21,8\left(E_{1}\right), 22,4\left(E_{2}\right)$ e $22,3\left(E_{3}\right)$. Isto sugere, em primeiro lugar, que os dois parentais exóticos transmitiram os genes para alto \%OL a suas progênies e, em segundo lugar, para que estes genes se expressem, necessitam ser transferidos para um genoma mais adaptado, principalmente em relação ao ciclo de maturidade.

Os coeficientes de variação experimental para médias de parcelas $(2,0 \% \leq \mathrm{CVe} \%$ $\leq 30,1 \%)$ e os coeficientes de determinação $\left(0,88 \leq R^{2} \leq 0,99\right)$ mostram condições experimentais normais e significativa proporção da variação dos dados, explicada pelos modelos estatísticos para todos os caracteres. Os dados correspondentes à \%OL tiveram ajuste menor $\left(0,78 \leq R^{2} \leq 0,88\right)$, provavelmente devido aos desvios adicionais de leitura do conteúdo correspondentes ao NMR. As análises gráficas de resíduos ao nível de médias de parcelas (Figura A) de acordo com Rocha (1998), mostram que os 
dados na escala original se ajustam às suposições da análise da variância, com desvios da normalidade dos resíduos padronizados para: $\operatorname{IPG}_{(1)}\left(-8\right.$ e +10) e $\operatorname{IPG}_{(2)}(-4,5$ e 4,5).

No que diz respeito ao número de plantas a partir das quais foram obtidas as médias de $\mathrm{T}$, este foi reduzido em $20 \%$ pelas condições de ambiente (estande final = 58 plantas/T) em relação ao estande inicial de 72 plantas. Embora o tamanho de amostra (plantas/T) seja insuficiente, considerando-se a natureza quantitativa dos caracteres estudados, o número de cruzamentos tem sido mais importante na exploração da variabilidade genética. $O$ tamanho mínimo de amostra, definido como o número mínimo de indivíduos necessários para se estimar com precisão aceitável a média e a variância de uma população, foi de 45 plantas para populações homogêneas e de 75 para heterogêneas. Já para estimar a variância, um número maior de plantas deve ser amostrado (Toledo \& Gilioli, 1981). Embora a unidade experimental representada por parcela de covas não represente as condições normais de cultivo com alta densidade e competição, possibilita a avaliação de plantas individuais em populações segregantes de soja. A reduzida e/ou nula competição associada à expressão do máximo potencial genético das plantas permite a diferenciação entre populações. Parcelas de cinco a sete plantas/covas, espaçadas a $60 \mathrm{~cm}$ entre as covas, têm mostrado as melhores estimativas de produtividade, comparado às parcelas tradicionais (Porto \& Vernetti, 1981).

\subsection{Análises de variância conjuntas}

As análises de variância conjuntas para $E$ com desdobramento da interação $T x$ E em efeitos de $\mathrm{P} \times \mathrm{E}$ e $\mathrm{Cr} \times \mathrm{E}$, e destes últimos em efeitos de $\mathrm{CP} \times \mathrm{E}, \mathrm{C}$ r $\times \mathrm{E}, \mathrm{P} \times \mathrm{E} / \mathrm{CP}$ e $\mathrm{Cr} \times \mathrm{E} / \mathrm{CCr}$ são apresentadas na Tabela 4. O primeiro desdobramento mostrou efeitos significativos ( $\mathrm{p}<0,05$ e $\mathrm{p}<0,01$ ) dos quadrados médios para todos os caracteres com magnitude dos valores do teste $F$ variando de 1,6 a 3,4. $O$ segundo desdobramento detectou interações significativas $(\mathrm{p}<0,05$ e $\mathrm{p}<0,01)$ dos quadrados médios de $\mathrm{P} x$ E/CP.3 para todos os caracteres, exceto para PR; e significância dos quadrados médios para \%OL nos três ciclos de maturidade. Destacaram-se também os efeitos significativos ( $\mathrm{p}<0,05$ e $\mathrm{p}<0,01$ ) dos quadrados médios de $\mathrm{Cr} \times \mathrm{E} / \mathrm{CCr} .1$ e $\mathrm{Cr} \times$ 
E/C $\mathrm{Cr} .2$ para \%OL, $\mathrm{Cr} \times \mathrm{E} / \mathrm{CCr} .4$ para todos os caracteres, exceto para \%OL, e de $\mathrm{Cr} \times$ $\mathrm{E} / \mathrm{CCr}$.6 para todos os caracteres, exceto NDF, $\mathrm{IPG}_{(1)}$ e \%OL.

Embora os efeitos das interações $P \times E$ e Cr $\times$ E sejam significativos $(p<0,05$ e $p$ $<0,01)$ para todos os caracteres, $o$ desdobramento das interações em parte complexa (\%PC) e simples (\%PS) (Tabela 5) indica que apenas as interações envolvendo os caracteres $\mathrm{PR}, \mathrm{IPG}_{(2)}$ e \%OL apresentam $\% \mathrm{PC} \geq 50 \%$. Para os outros caracteres predomina a parte simples $(53,2 \leq \mathrm{PS} \leq \mathbf{8 8 , 6 )}$, mostrando que as interações não interferem significativamente com o processo de seleção baseada na média das $\mathrm{E}$.

Embora as épocas de semeadura não devam ser consideradas como substitutas dos efeitos de anos, quando associadas a avaliạções em diferentes locais, permitem obter informações sobre o comportamento genotípico no tempo e no espaço num mesmo ano agrícola, além de informações sobre fotossensibilidade e período juvenil. Métodos tais como o modelo AMMI (ㅅdditive Main Effects and Multiplicative Interaction Analysis) sugerido por (Gauch \& Zobel, 1996, entre outros), deverão ser empregados com maior ênfase no estudo das interações, envolvendo épocas $\mathrm{x}$ anos. A análise da natureza e magnitude destas interações pode trazer grandes benefícios ao melhoramento, principalmente no que se refere à substituição de anos por épocas como estratégia de encurtamento do tempo de avaliação de cultivares. Isto tem maior importância quando identificadas interações pouco expressivas.

Os quadrados médios correspondentes aos efeitos de $\mathrm{E}$ foram significativos $\mathrm{p}<$ 0,05 e $\mathrm{p}<0,01$ ) para \%OL, APM, NDM, NDF e PR com magnitude dos valores do teste de $F$ variando de 12 a 85 . A estratificação de $E$, com base na interação não-significativa entre genótipos e pares de $\mathrm{E}$ (Tabela 5), indica que as $\mathrm{E}_{2}$ e $\mathrm{E}_{3}$ podem ser consideradas iguais, e diferentes da $E_{1}$, exceto para NDF, $\mathrm{IPG}_{(1)}$ e $I P G_{(2)}$. Assim, as $E_{2}$ e $E_{3}$ oferecem informações similares sobre o comportamento dos genótipos para a maioria dos caracteres estudados. A estratificação de ambientes baseada em padrões de similaridade de respostas de cultivares, permite a identificação de localidades em que a interação possa ser não significativa (Cruz \& Regazzi, 1997). Isto contorna os inconvenientes proporcionados pela interação genótipos $x$ ambientes, principalmente em redes de avaliação de cultivares. A correta escolha de ambientes de avaliação 
permite reduzir a magnitude das interações $G \times A$, aumentando a herdabilidade, o que, por sua vez, tem influência na pressão de seleção.

\subsection{Análises das médias}

As médias e as amplitudes de variação de parentais e cruzamentos agrupadas em ciclos de maturidade $\mathrm{P} / \mathrm{C}^{\mathrm{P}}$ e $\mathrm{Cr} / \mathrm{CCr}$, de acordo com o NMDM para cada $\mathrm{E}$, são apresentadas nas Tabelas 6 a 8. Como foi mostrado pela significância $(p<0,01)$ dos efeitos $\mathrm{P}$ vs $\mathrm{Cr}$, as médias dos parentais para NDF e NDM são maiores que as médias de cruzamentos nas três $E$; entretanto, para $P R$ e $I P G_{(2)}$ as médias dos parentais são menores na $E_{1}$. A significância $(p<0,05$ e $p<0,01)$ dos efeitos de $E$ mostra que as médias gerais para NDM $(133,8)$ e PR $(89,7)$ foram superiores na $E_{1}$, para APM $(55,0)$ e $\%$ OL $(21,5)$ na $E_{3}$, e para NDF $(47,7)$ na $E_{2}$.

Embora os efeitos de E (Tabela 4) não sejam significativos ( $p<0,05)$ para PG, $\mathrm{IPG}_{(1)}, \mathrm{IPG}_{(2)}$ e PO, devido à magnitude dos quadrados médios dos efeitos de blocos (B)/E, observou-se que as médias na $\mathrm{E}_{3}$ são $25,8 \%$ (PG), 39,9\% (IPG $\left.(1)\right), 22,8 \%\left(\mathrm{IPG}_{(2)}\right)$ e $27,0 \%(\mathrm{PO})$, maiores que a média das $\mathrm{E}_{1}$ e $\mathrm{E}_{2}$. Isto é explicado, principalmente, pela relação existente entre o número médio de dias para o florescimento de cada $\mathrm{E}$, e a data de florescimento. Assim, a $\mathrm{E}_{1}(28 / 10 / 97)$ e a $\mathrm{E}_{2}$ (12/11/97), com média de 43,8 e 47,7, respectivamente, tiveram o pico de floração entre os dias 11/12/97 e 30/12/97 (Solstício de verão); já a $E_{3}(26 / 11 / 97)$, com média de 46,5 , teve o pico de floração no dia 12/01/98; portanto, o início do desenvolvimento de vagens foi coincidente com a redução do fotoperíodo, o qual reduz a taxa de aborto fisiologico de flores e vagens. A abscisão de flores e vagens pode alcançar taxas de $40 \%$ a $80 \%$, e o abortamento de 6́vulos e sementes em vagens maduras de $9 \%$ a $22 \%$ (Castro, 1998). O autor também aponta o fotoperiodo longo e as altas temperaturas como causas que promovem esta aborção.

Para os grupos de ciclos de maturidade observou-se que os grupos $\mathrm{P} / \mathrm{C}^{\mathrm{P}} .3$, nas três $\mathrm{E}, \mathrm{Cr} / \mathrm{Cr}$.6, na $\mathrm{E}_{1}$, e $\mathrm{Cr} / \mathrm{CCr}_{\text {.7 }}$, nas $\mathrm{E}_{2}$ e $\mathrm{E}_{3}$, apresentaram as maiores médias para PG, IPG $(1), I_{(2)}$ e PO. Assim, os resultados mostram que para ganhos máximos, a seleção deverá ser feita de preferência sobre genótipos com tempo para o florescimento 
e a maturidade, variando de 41 a 72 dias e 136 a 160 dias, respectivamente, dependendo da época de semeadura.

Para observações de plantas individuais, foi destacada a $E_{3}$ com os maiores quartis $3(75 \%)$ para todos os caracteres, exceto para PR com maior quartil na $E_{1}$. Isto mostra que na $E_{3}$ encontram-se $\mathbf{2 5 \%}$ das plantas com os maiores valores para a maioria dos caracteres e, portanto, a melhor E para a seleção de plantas individuais.

As médias gerais dos parentais e cruzamentos são mostradas na Tabela 9. Observou-se que para NDF, NDM, PR e APM os T com menores médias foram PI 371.611 e PI 181.544 para NDF e NDM; USP8-13 x PI $181.544(5 \times 7)$, USP2-1 x PI 181.544 (4 × 7) e PI 181.544 para PR; e Lamar x PI 181.544 ( 2 × 7), Lamar e PI 181.544 para APM. Os T que se destacaram com maiores médias foram as USP do G2 para NDF e NDM; USP1-19 x USP93-5580 (3 × 9), USP1-19 x USP93-5953 (3 × 13) e USP1-19 para PR; e USP1-19 x USP93-5884 ( 3 × 12) e USP1-19 x USP93-5580 ( 3 × 9) para APM.

Os cruzamentos que apresentaram maiores médias para os outros caracteres foram: USP8-13 x USP93-5884 (5 x 12) e USP8-13 x USP93-5953 $(5 \times 13)$ para PG, IPG(1) e PO; USP8-13 x USP93-5953 (5 x 13) e USP8-13 x USP93-5766 $(5 \times 10)$ para IPG $(2)$; e USP8-13 x USP93-5953 ( 3 x 13), USP1-2 $x$ USP93-5580 ( 4 x 9), USP1-19 x USP93-5884 (3 $x$ 12), USP1-19 x USP93-5380 ( $3 \times 8)$ e USP1-19 x USP93-5580 $(3 \times 9)$ para \%OL, com valores médios acima de $22 \%$.

\subsection{Análise de correlações parciais}

As estimativas dos efeitos genéticos diretos (EGD) e dos efeitos genéticos indiretos (EGI) de caracteres explicativos sobre os caracteres principais: PG, IPG $\mathrm{I}_{(1)}$, $\mathrm{IPG}_{(2)}$ e PO são apresentadas na Tabela 10. Observou-se que os EGD e EGI maiores e positivos dos caracteres explicativos correspondem a NDF sobre o caráter principal PG $(\geq 0,58)$, e a PG sobre $\operatorname{IPG}_{(1)}(\geq 0,84), \mathrm{IPG}_{(2)}(\leq 1,67)$ e $\mathrm{PO}(\geq 0,47)$. Foi observado também que há correlação genética simples positiva $(\mathrm{rg}=0,94)$ entre PG e NDM; no entanto, o desdobramento do coeficiente de correlação destacou os efeitos genéticos diretos e indiretos negativos do NDM sobre PG $(-0,73 \leq \mathrm{EGI} \leq-0,59$ e EGD $=-0,78)$. Isto mostra que as correlações positivas de PG com ciclo de maturidade são biologicamente 
determinadas, principalmente, pelos genes responsáveis pela resposta fotoperiódica e, em menor escala, pela duração do $P R(E G D=0,53)$, e não pelo EGD do ciclo completo de maturidade.

Assim, embora a adaptação fotoperiódica deva ser estudada em todas as fases [incluindo o desenvolvimento de vagens (Bhatia et al., 1997)], o início da floração e do desenvolvimento das vagens representam os principais estádios fisiológicos que determinam o potencial produtivo. Observou-se também que, embora o efeito da APM sobre a PG seja positivo, não mostra forte associação entre ambos (EGD =0,35). Portanto, o potencial genético de desenvolvimento vegetativo, principalmente na disponibilidade de nós reprodutivos, é mais importante do que o crescimento em altura para o potencial produtivo.

Os melhores genótipos podem ser selecionados com base no número de sementes/planta, peso de 100 sementes e número de ramificações, além dos dias para a floração e da altura da planta (Mehetre et al., 1994 e Taware et al., 1997). Embora o número de ramificações seja um caráter influenciado pelo sistema e densidade de cultivo e um dos principais fatores responsáveis pela disponibilidade de nós reprodutivos/planta, a seleção não deve ser conduzida em favor de ideótipos fortemente ramificados e de ampla cobertura, devido aos fatores limitantes da produtividade provocados pelas epidemias de fungos patogênicos (Bruno, $1997 \mathrm{e}$ Yorinori, 1998). Vários aspectos de manejo do cultivo podem auxiliar o uso da resistência genética no controle de doenças (Sinclair, 1994), entre eles, o uso de genótipos eretos e pouco ramificados, os quais também favorecem a redução da taxa de aborto de flores e vagens na parte inferior da planta, provocada por excessivo sombreamento. A abscisão de botões florais, flores e vagens é desproporcionalmente superior nos nós inferiores e nas ramificações (Castro, 1998).

Com respeito à PO e a sua relação com \%OL, foi observado que, embora haja correlação genética simples positiva $(\mathrm{rg}=0,75)$ entre ambos os caracteres, o EGD =0,05 para \%OL e EGD = 0,64 para PG indica que a \%OL apresenta pouca influência sobre a PO e que a contribuição para a correlação é dada principalmente pela PG. Isto é explicado, principalmente, pela baixa variabilidade genética existente para \%OL, como 
demonstrado pela escassa importância agronômica da magnitude dos valores do teste F para parentais e cruzamentos $(2,3 \leq \mathrm{F} \leq 7,3)$ nas análises de variância das três $\mathrm{E}$. Assim, embora as correlações entre PG e \%OL sejam positivas, o aumento da PO como caráter de importância comercial depende das mudanças nas freqüèncias alélicas para capacidade produtiva de grãos (Laínez-Mejía, 1996).

As análises de correlações parciais foram feitas a partir de uma matriz de correlações genéticas, na qual foi diagnosticada a existência de multicolinearidade entre variáveis, através do procedimento "Álgebra de matrizes" do Programa GENES® (1997). A multicolinearidade entre as variáveis $X 1, X 2$ e $Y$ indica uma relação quase perfeita; no entanto, a variável $X 1$ pode não estar correlacionada com $Y$ quando é eliminado o efeito da variável X2, e vice-versa (Steel \& Torrie, 1985). A fim de atenuar os efeitos da multicolinearidade entre as variáveis, foi introduzida a constante $K=$ 0,003846 na diagonal da matriz $X^{\prime} X$. Para se condicionar a matriz, deve-se escolher $o$ menor valor de $K$, para o qual a maioria dos coeficientes de caminhamento, associados aos vários caracteres, estejam estabilizados (Carvalho, 1995).

\subsection{Análises dialélicas}

As análises de variância com desdobramento de T em efeitos de G1, G2 e G, segundo o modelo de Gardner \& Eberhart (1966), adaptado por Miranda-Filho \& Geraldi (1984); e com desdobramento de cruzamentos em CGC e CEC, segundo o modelo de Griffing (1956), adaptado por Geraldi \& Miranda-Filho (1988), são apresentadas na Tabela 11.

Para os efeitos do G1 e G2 foram observadas diferenças significativas $(p<0,01)$ dos quadrados médios para todos os caracteres, com magnitudes dos valores do teste $\mathrm{F}$ de 21 e 25 para \%OL, 225 para APM, e 540 para NDF. Os efeitos G1 vs G2 mostraram diferenças significativas $(p<0,01)$ dos quadrados médios para todos os caracteres, exceto para $\% \mathrm{OL}$, com valor do teste $\mathrm{F}$ de 0,8 . Os resultados indicam a existencia de variabilidade entre e dentro de $G$ para todos os caracteres, principalmente para NDF, NDM e APM, exceto para \%OL entre parentais. Em termos de PO, as diferenças entre os dois $\mathrm{G}$ são dadas pela alta PG e não pela \%OL. As médias de $\mathrm{G} 2>\mathrm{G} 1$ indicam que o 
G2 contém maior freqüência de alelos que aumentam a expressão fenotípica dos caracteres, exceto para \%OL.

Para os efeitos de CGC-G1 e CGC-G2 observaram-se diferenças significativas ( $p$ $<0,01)$ dos quadrados médios para todos os caracteres, com magnitude dos valores do teste $F$ variando de 11 a 53 no G1 e de 16 a 86 no G2. Para os efeitos de CEC observouse diferenças significativas $(p<0,05$ e $p<0,01)$ dos quadrados médios para todos os caracteres, exceto para $\mathrm{IPG}_{(2)}(\mathrm{F}=1,6)$ e $\% \mathrm{OL}(\mathrm{F}=1,2)$. A magnitude dos valores do teste $\mathrm{F}$ evidenciam que o desempenho médio dos parentais em combinações híbridas é superior ao comportamento heterótico dos cruzamentos individuais, embora a CGC não seja propriedade fixa do genótipo, pois depende da composição genética do parental com o qual se cruza.

As estimativas de CGC-G1 (gi), CGC-G2 (gj), CEC (gij), G1 (vi) e G2 (vj), são apresentadas na Tabela 12. Para a CGC-G1, as menores estimativas de gi foram apresentadas por Hartwig para NDM $(-5,29)$, PR $(-2,63)$ e APM $(-9,50)$; e por Lamar para NDF $(-3,79)$. Já as maiores estimativas foram apresentadas por USP1-19 para PR $(4,95)$, APM $(20,2)$ e \%OL $(0,72)$; e por USP8-13 para NDF $(5,13)$, NDM $(5,34)$, PG $(25,5)$, IPG $_{(1)}$ $(0,30), \mathrm{IPG}_{(2)}(0,44)$ e $\mathrm{PO}(5,17)$.

Para a CGC-G2, as menores estimativas de $g j$ foram apresentadas por PI 371.611 para NDF $(-10,0)$; e por PI 181.544 para NDM $(-16,8)$, PR $(-7,82)$ e APM $(-20,4)$. No entanto, as maiores estimativas foram apresentadas por USP93-5580 para PR $(5,38)$ e \%OL (0,58); USP93-5766 para IPG $_{(2)}(0,49)$; USP93-5884 para APM $(28,4)$, PG $(40,6)$, $\mathrm{IPG}_{(1)}(0,45)$ e PO $(8,91)$; e por USP93-5953 para NDF $(4,51)$ e NDM $(9,70)$.

Para a CEC, as menores estimativas de gij foram mostradas pelos cruzamentos USP1-19 x PI $371.611(3 \times 6)$ para APM $(-13,9)$ e USP8-13 x PI $181.544(5 \times 7)$ para NDF $(-2,89)$, NDM $(-8,54)$ e PR $(-5,37)$. As maiores estimativas foram apresentadas pelos cruzamentos Hartwig x USP93-5884 $(1 \times 12)$ para APM $(10,3)$, PG $(36,0), \mathrm{IPG}_{(1)}(0,41)$ e PO (8,18); USP1-19 x PI 181.544 ( $3 \times 7)$ para NDM (5,45); USP8-13 x PI $371.611(5 \times 6)$ para \%OL (0,57); USP8-13 x USP93-5766 (5 x 10) para PR (3,99); USP8-13 x USP93-5884 $(5 \times 12)$ para NDF $(2,64)$; e USP8-13 x USP93-5953 $(5 \times 13)$ para IPG $_{(2)}(0,43)$. Observouse correspondência entre estas máximas $(+;-)$ estimativas de $g i j$ com estimativas de $g i$ 
e gj de sinal contrário, exceto nos cruzamentos USP8-13 x PI $371.611(5 \times 6)$ para \%OL, USP8-13 x PI 181.544 ( 5 × 7) para PR, USP8-13 x USP93-5884 (5 x 12) para NDF, e USP8$13 \times$ USP93-5359 $(5 \times 13)$ para IPG $_{(2)}$; destacando-se o envolvimento dos genótipos exóticos (Hartwig, PI 371.611 e PI 181.544) nestes cruzamentos. Com isto, pode ser demonstrada a importância da divergência genética na manifestação da CEC, como indicado por Freire Filho (1988). Outro fator que pode estar favorecendo o comportamento heterótico destes cruzamentos é a ligação em repulsão "sobredominância aparente" de genes envolvidos na determinação genética do mesmo caráter.

As estimativas mínimas ( $\left.\mathrm{IPG}_{(1)}\right)$ e máximas (PG) das variâncias associadas aos efeitos da CGC-G1 $\left(0,043 \leq s^{2}{ }_{g i} \leq 364,3\right)$, CGC-G2 $\left(0,133 \leq s^{2}{ }_{g j} \leq 1143\right)$ e CEC $\left(0,009 \leq s^{2}{ }_{\text {gij }}\right.$ $\leq 70,64)$ mostram que a magnitude da variância da CGC-G2 é de 1,3 a 5,4 vezes maior que a magnitude correspondente à CGC-G1, e de 6,5 a 27,2 vezes maior que a correspondente à CEC. Isto evidencia que os efeitos genéticos envolvidos na determinação dos caracteres são predominantemente de natureza aditiva, sendo o G2 o mais promissor para uso em programas de melhoramento. Resultados similares também foram obtidos por Cruz et al. (1984) para NDF e PR em materiais adaptados; no entanto, as estimativas dependem, principalmente, do tipo de genótipo empregado: cultivares ou genótipos pré-melhorados (Qi \& Jinling, 1994).

Observa-se que para PG, a variância da CEC ( $\left(\mathrm{s}_{\mathrm{gij}}\right)$ representa $9,4 \%$ da magnitude da variância média da CGC $\left.\left(s^{2}{ }_{g i}+s^{2}{ }_{g j}\right) / 2=735,7\right)$, o que em termos de produtividade média $\left(2 \times 10^{3} \mathrm{Kg} / \mathrm{ha}\right)$ representa $188 \mathrm{~kg} /$ ha para a geração $\mathrm{F}_{2}$ e 376 $\mathrm{Kg} / \mathrm{ha}$ para a geração $F_{1}$. Embora este vigor híbrido encontrado seja um aspecto importante em termos acadêmicos, não representa importância comercial, uma vez que na prática há dificuldades em se obter número suficiente de sementes $F_{1}$ de soja. Bruno (1997) obteve uma heterose média de $137 \%$ para PG em relação à média dos parentais.

Para o efeito de variedades do G1, as menores estimativas (vi) foram apresentadas por Lamar para NDF $(-5,57)$, NDM $(-7,10)$ e APM $(-15,8)$; e por USP2-1 para PR $(-5,60)$. Já maiores estimativas foram apresentadas por USP1-19 para NDM 
$(8,90)$, PR $(12,4)$, APM $(35,7)$ e \%OL $(1,02)$; e por USP8-13 para NDF $(7,43)$, PG $(36,2)$, $\mathrm{IPG}_{(1)}(\mathbf{0}, 48), \mathrm{IPG}_{(2)}(0,99)$ e PO $(7,35)$.

Para o efeito de parentais do G2, as menores estimativas (vj) foram apresentadas por PI 371.611 para NDF $(-26,2)$; e por PI 181.544 para NDM $(-33,4)$, PR ($8,96)$ e APM $(-34,1)$. As maiores estimativas foram apresentadas por USP93-5380 para $\mathrm{IPG}_{(1)}(0,74)$ e \%OL $(1,02)$; USP93-5580 para NDM $(14,9)$ e PR $(8,21)$; USP93-5766 para $\mathrm{IPG}_{(2)}(0,91)$; USP93-5884 para APM $(26,2)$, PG $(59,9)$ e PO $(13,5)$; e USP93-5953 para NDF $(12,7)$.

Em geral observa-se que para as máximas estimativas houve correspondência entre $g i$ e $u i$, e $g j$ e $v j$; isto mostra que a CGC se deve, principalmente, ao efeito intrínseco dos genes e não aos efeitos heteróticos. As interpretações da análise da CGC podem diferir daquelas que consideram os componentes $v i$ e $v j$, principalmente quando suas contribuições são variáveis (Paludzyszyn \& Miranda-Filho, 1981). Resumindo as informações sobre estas estimativas, os seguintes parentais tiveram destaque como os mais promissores para uso em programas de melhoramento:

\section{Grupo 1:}

Lamar: $\quad$ menores gi e vi para NDF;

Hartwig: $\quad$ menores gi para NDM, PR e APM;

USP1-19: maiores gi e vi para PR, APM e \%OL, e maior vi para NDM;

USP8-13: maiores gi e vi para NDF, PG, $\mathrm{IPG}_{(1)}, \mathrm{IPG}_{(2)}$ e PO, e maior gi para NDM;

Grupo 2:

PI 371.611: menores gj e vj para NDF;

PI 181.544: menores $g j$ e $v j$ para NDM, PR e APM;

USP93-5580: maiores gj e vj para PR, e maior gj para \%OL;

USP93-5766: maiores gj e vj para $\mathrm{IPG}_{(2)}$;

USP93-5884: maiores gj e vj para APM, PG e PO, e maior $g j$ para $\mathrm{IPG}_{(1)}$;

USP93-5953: maiores gj e vj para NDF, e maior gj para NDM;

$\mathrm{Na}$ Tabela 13 são apresentados os coeficientes de regressão (b) de W (covariâncias) em função de $\mathrm{V}$ (variâncias) correspondentes aos testes de suficiência do modelo aditivo-dominante e as estimativas dos componentes genéticos aditivos e 
dominantes (D, F, H1 e $H 2)$ de cada grupo, segundo o modelo de Hayman (1954), adaptado por Viana (1994). Os componentes foram testados pelo teste " $t$ ", e os valores de $t_{\text {obs }} \geq 2,20,2,26$ e 2,37 para $t_{n-2 ; 0,05}$ e $t_{o b s} \geq 3,11,3,25$ e 3,50 para $t_{n-2 ;} 0,01$ foram significativos.

Para os dados na escala original foram observados coeficientes de regressão $\left(\mathrm{H}_{0}\right.$ : $\mathrm{b}=1$ ) significativos $(\mathrm{p}<0,05$ e $\mathrm{p}<0,01)$ no $\mathrm{G} 1$ para todos os caracteres, exceto para PG

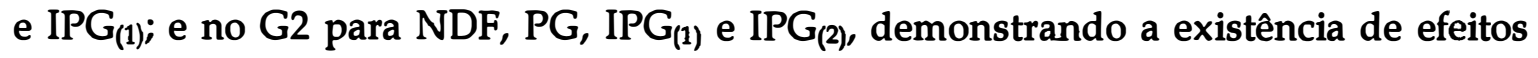
epistáticos envolvidos na herança destes caracteres. Sendo a aditividade a ação gênica predominante, sugere-se que o tipo principal de interações interalélicas provavelmente seja aditivo $x$ aditivo, o qual é aproveitável no processo de seleção.

Para os dados na escala logarítmica $[\log (x+1)]$, os coeficientes de regressão $\left[\left(\mathrm{H}_{0}: \mathrm{b}=1\right) 0,61 \leq \mathrm{b} \leq 1,18\right]$ foram não-significativos $(\mathrm{p}<0,05)$ para todos os caracteres, exceto para \%OL, significativo $(\mathrm{p}<0,01)$ para $\mathrm{H}_{0}: \mathrm{b}=0$, que foi mantido na escala original. Estes resultados demostram que o emprego dos dados na escala logarítmica $[\log (x+1)]$ neutralizaram os efeitos que não permitiram a suficiência do modelo na escala original. Além da transformação, foi necessária a eliminação de parentais (I - 1) x ( - 1) para se obter suficiência do modelo para NDM, PR e APM. Já para \%OL, o procedimento usado envolveu somente a eliminação de parentais. Após estes procedimentos de ajustes, observou-se a eficiência do modelo aditivo-dominante através dos coeficientes de determinação $\left(R^{2}=0,998-0,999\right)$. Freire Filho (1988) concluiu que, mesmo com a eliminação de parentais, os dados para a maioria dos caracteres não atenderam plenamente às restrições do modelo de Hayman (1954) para dialelos completos.

Entre as suposições do modelo de Hayman (1954), a presença de efeitos epistáticos (Lark et al., 1995) e de alelismo múltiplo associado à origem poliplóide do genoma da soja, podem ser as principais causas dos desvios significativos dos dados originais em relação ao modelo. Segundo estudos moleculares de origem e evolução filogenética e distribuição biogeográfica (Hymowitz et al., 1997; Terry et al., 1995 e Van Raamsdonk, 1995), o gênero Glycine teria origem poliplóide a partir de um ancestral diplóide $(n=11)$ por aneuploidização $(n-1=10)$, seguido de poliploidização, 
originando o genoma atual da soja (GG, $2 n=4 x=40$ ). Portanto, $G$. max é considerada uma espécie tetraplóide estável com genoma diploidizado por diversificação de seqüências e reestruturação cromossômica originada a partir do ancestral G. soja.

Outro aspecto importante em relação aos desvios do modelo aditivodominante, refere-se aos genótipos exóticos empregados no esquema dialélico, principalmente para os caracteres APM e \%OL, cuja eliminação permitiu o ajuste dos dados. No caso de APM, o ajuste dos dados originais ao modelo só foi obtido após a eliminação dos quatro parentais exóticos (Hartwig, Lamar, PI 371.611 e PI 181.544). Isto indica que a inclusão nos cruzamentos de genótipos selecionados para caracteres específicos (Anand, 1992 e Hartwig et al., 1990), e divergentes geograficamente, leva à manifestação de efeitos genéticos pouco comuns nos cruzamentos adaptado $x$ adaptado; no entanto, Mehetre et al. (1994) indicaram que a divergência geográfica pode ser independente da divergência genética.

A seleção de progênies para caracteres específicos, dentro de programas de melhoramento, pode provocar assimetrias acentuadas na distribuição dos genes nos parentais e, portanto, desvios de parentesco estimado pelo coeficiente de parentesco (Kisha \& Diers, 1997; Vello et al., 1988). Marcadores moleculares podem detectar estes desvios e facilitar assim, o agrupamento e seleção dos parentais para uso em cruzamentos específicos (Moreira et al., 1994). No caso do cultivar Hartwig (Forrest (3) $\mathrm{x}$ PI 437.654), a transferência de genes de resistência a Nematóide ao Cisto da Soja (NCS) derivados da PI 437.654, ligados a outros alelos não presentes no "pool" de genes adaptados, ou à permanência de $6,25 \%$ do genoma da PI, podem ser parte das causas da falta de ajuste.

O uso de genótipos exóticos é uma estratégia para a incorporação de novos genes e para a ampliação da variabilidade, como foi demonstrado pela associação inversa entre coeficiente de parentesco e variância genética, através de marcadores moleculares (Manjarrez-Sandoval et al., 1996). No entanto, é importante salientar que as dificuldades de incorporar exclusivamente os genes de interesse podem retardar os benefícios promovidos pela transferência desses genes aos genótipos adaptados. $\mathrm{O}$ uso exclusivo de germoplasma elite nos programas de melhoramento pode evitar a 
redução da diversidade e, portanto, contribuir à manutenção de suficiente variabilidade para a seleção (Rasmusson \& Phillips, 1997).

As estimativas dos componentes de variância, devido aos efeitos aditivos (D1 e D2), destacaram-se por terem mostrado significância $(\mathrm{p}<0,01)$ para todos os caracteres, indicando que há genes não fixados $(p=q \neq 1)$ em ambos os $G$ e, portanto, os parentais apresentam variabilidade genética aproveitável na seleção das progênies derivadas dos cruzamentos entre eles. Resultados similares também foram obtidos por Freire Filho (1988) para cruzamentos dialélicos completos.

As estimativas dos componentes de variância correspondentes aos efeitos de dominância (H1-G1, H1-G2 e H2-médio), ainda que positivas para a maioria dos caracteres, não mostram efeitos significativos $(\mathrm{p}<0,05)$, indicando o predomínio dos efeitos aditivos em ambos os grupos.

As estimativas dos componentes de variância correspondentes aos efeitos das freqüências de alelos recessivos e dominantes no G1 mostraram efeitos de F-G1, positivos e significativos ( $\mathrm{p}<0,01$ ) para NDF e NDM; e efeitos de F-G1, negativos e significativos ( $\mathrm{p}<0,05$ e $\mathrm{p}<0,01$ ) para $\mathrm{PR}, \mathrm{PG}, \mathrm{IPG}_{(1)}, \mathrm{IPG}_{(2)}$ e PO; indicando maior freqüência de alelos dominantes e recessivos, envolvidos na determinação genética destes caracteres. No G2, observou-se efeito significativo ( $\mathrm{p}<0,01)$ de $F^{\prime}-\mathrm{G} 2$, positivo para PR e negativo para \%OL, mostrando a predominância de alelos dominantes e recessivos na determinação genética destes caracteres.

A análise do grau médio de dominância (gmd) mostrou a existência de dominância completa (gmd $\cong 1$ ) para NDM no G1 e sobredominância para PR (gmd = 1,899) e APM (gmd = 2,712) no G2; já para os demais caracteres foi detectada dominância parcial $(0,236 \leq$ gmd $\leq 0,908)$. Resultados similares para NDF, APM e PG foram obtidos por Freire Filho, (1988). Embora o $F<0$ associado à sobredominância para APM no G2 seja não-significativo ( $\mathrm{p}<0,05)$, o caráter pode ser controlado por genes recessivos em maior freqüência e por alguns genes principais com fortes desvios de dominância, o que, segundo Cruz et al. (1984), representa proporção importante da variância. Segundo Mansur et al. (1993), os marcadores de RFLP R79 e G173 explicaram $31 \%$ e $53 \%$ da variação em altura de planta, respectivamente. 
A proporção entre genes dominantes e recessivos $(d / r)$ indicou que há maior freqüência de alelos dominantes $(1,463 \leq \mathrm{d} / \mathrm{r} \leq 13,13)$ na determinação genética dos caracteres NDF no G1; NDM nos G1 e G2; e PR e IPG $(2)$ no G2; no entanto, houve predominância de alelos recessivos $(\mathrm{d} / \mathrm{r}=0,042)$ no $\mathrm{G} 1$ para PG. Para os outros caracteres, observou-se maiores freqüências de alelos recessivos $(0,165 \leq \mathrm{d} / \mathrm{r} \leq 0,714)$ e $(F<0)$ envolvidos na expressão fenotípica em ambos os $\mathrm{G}$. Os valores de $F>0$ para \%OL no G1, e PG e PO no G2, mesmo sendo não-significativos $(p<0,05)$, sugerem a presença de alelos dominantes.

Os coeficientes de herdabilidade no sentido restrito $\left(h^{2} \geq 0,415\right)$ indicam a importância das contribuições dos desvios de sobredominância para PR e APM, e da freqüència de alelos dominantes para IPG(2) no $\mathrm{G} 2$.

Na Tabela 13 também são apresentadas as estimativas dos componentes de variância correspondentes aos efeitos das freqüências de alelos recessivos e dominantes para cada parental, e as Figuras B e C permitem analisar a proporção $d / r$ através da distribuição dos parentais ao longo da reta de regressão (b) para cada caráter. Esta distribuição está baseada no princípio de que os parentais com maior número de genes dominantes produzirão progênies com mínima variância entre si ( $\mathrm{Vr}, \mathrm{Vs})$ e mínima covariância parental-progênie (Wr, Ws). Assim, quanto mais próxima a localização à origem da reta $(O)$ no gráfico de regressão linear de $W$. em função de $V$. , maior a concentração de alelos dominantes. Foi observado que para a maioria dos caracteres, os parentais mais distantes da origem apresentam maior freqüência de alelos recessivos ( $F$ $<0)$.

Considerando-se a magnitude das estimativas $g i, v i, g j$ e $v j$, e com base no sinal $(+;$-) das estimativas $F$, e a proporção $\mathrm{d} / \mathrm{r}$ de cada parental, é possível indicar quais populações terão maior resposta à seleção. Os cruzamentos envolvendo parentais com estimativas de $F$ do mesmo sinal (mesmo tipo de ação gênica predominante) terão maior potencial de ganho por seleção precoce (SP); no entanto, a seleção dentro dos cruzamentos, envolvendo parentais com estimativas de $F$ de sinal oposto, será mais eficiente em gerações avançadas de endogamia. Assim, sugerem-se as seguintes 
populações $\mathrm{F}_{2}$ como as de maior potencial de ganho genético por SP e seleção tardia (ST):

Para diminuir a expressão:

NDF: (Lamar $\times$ PI 371.611), SP;

NDM: (Hartwig x PI 181.544), ST;

PR: $\quad$ (Hartwig $\times$ PI 181.544), SP.

Para aumentar a expressão:

NDF: (USP8-13 x USP93-5953), ST;

PG: (USP8-13 $\times$ USP93-5884), ST;

\%OL: (USP1-19 x USP93-5580), SP;

PO: (USP8-13 x USP93-5884), ST.

Para NDF observou-se que as seis linhagens USP do G2 apresentaram efeitos significativos ( $\mathrm{p}<0,05$ e $\mathrm{p}<0,01)$ de $F<0$, ao contrário dos sete parentais restantes que apresentam efeitos significativos $(\mathrm{p}<0,05$ e $\mathrm{p}<0,01)$ de $F>0$. Isto demonstra que $o$ NDF é controlado principalmente por genes dominantes nos parentais exóticos e naqueles cuja genealogia envolve a presença de genótipos exóticos (Apêndice B1). Assim, o cultivar Forrest, envolvido na genealogia (fonte de genes de resistencia ao nematóide de cisto da soja, NCS) das USP1-19, USP2-1 e USP8-13 do G2 deve ser o responsável pela presença de genes dominantes para floração precoce nestes genótipos adaptados. Sob condições de dias curtos, os genótipos tardios são controlados por genes recessivos (Bonato, 1989), considerando-se que ocorre dominância parcial para precocidade (Gilioli et al., 1984).

Observou-se que para PG, PO e IPG (2) no G1; IPG $_{(1)}$ nos G1 e G2; e \%OL no G2, ocorreu predomínio de genes recessivos entre os parentais e predomínio de genes dominantes na PI 371.611 para todos os caracteres.

A Tabela 13 ainda permite analisar a direção de dominância (dd) para cada parental e grupo, ao comparar as estimativas $F, F^{\prime}, F-G 1$ e $F^{\prime}-\mathrm{G} 2$ com as médias de parentais e de grupos. No G2, destacou-se a presença dos genes recessivos que aumentam a expressão para NDF e \%OL (dominância unidirecional negativa); e dos genes dominantes responsáveis pelo incremento para $\mathrm{PG}, \mathrm{IPG}_{(2)}$ e $\mathrm{PO}$ (dominância 
unidirecional positiva). Já o parental USP8-13 contém significativa concentração de genes recessivos que aumentam a expressão para $P G, I_{(1)}, I_{(P G}$ e PO. O conhecimento do tipo de ação gênica (dominante, recessiva), associado com a magnitude de sua expressão, tem importantes implicações no melhoramento, principalmente na seleção de parentais, esquemas de cruzamentos e estratégias de seleção das progênies derivadas. $\mathrm{O}$ uso de parentais com as melhores CGC e com o mesmo tipo de efeitos não-aditivos que promovem mudanças desejáveis na magnitude da expressão fenotípica dos caracteres de interesse, pode ser de grande importância para auxiliar na tarefa de maximizar os ganhos genéticos. 
f) A magnitude da variância para capacidade geral de combinação do grupo 2 (CGC-G2) é 1,3 a 5,4 vezes maior que a magnitude correspondente à capacidade geral de combinação do grupo 1 (CGC-G1), e de 6,5 a 27,2 vezes maior que a correspondente à capacidade específica de combinação (CEC).

g) Os efeitos genéticos envolvidos na determinação dos caracteres são predominantemente de natureza aditiva; de menor importância relativa são os efeitos epistáticos e de dominância;

h) A distribuição das freqüèncias de alelos recessivos e dominantes mostra genes recessivos como responsáveis pelo aumento da expressão do número de dias para o florescimento (NDF) e \%OL (dominância unidirecional negativa), e genes dominantes responsáveis pelo incremento da $P G, I_{(2)}$ e $P O$ (dominância unidirecional positiva);

i) $\mathrm{O}$ conhecimento da distribuição dos alelos responsáveis pelos efeitos não aditivos e da magnitude de sua expressão fenotípica (direção de dominância) tem importantes implicações no melhoramento, principalmente na seleção de parentais, programação de cruzamentos e estratégia de seleção das progênies derivadas. $O$ uso de parentais, em função da capacidade de combinação, e com o mesmo tipo de efeitos não-aditivos promovendo mudanças desejáveis na expressão fenotípica dos caracteres de interesse, é um importante auxílio na tarefa de maximizar os ganhos genéticos.

j) Embora os genótipos exóticos ampliem a base genética, não oferecem vantagens em programas de melhoramento voltados à obtenção de cultivares a curto prazo e, portanto, devem ser pré-melhorados a fim de reduzir a freqüència de genes indesejáveis antes do seu emprego em cruzamentos. 


\section{REFERÊNCIAS BIBLIOGRÁFICAS}

AGROMERCADOS. Rapido ascenso del consumo mundial de aceites vegetales. v.5, n.10, p.70-71, 1995.

ANAND, S. C. Registration of Hartwig soybean. Crop Science, v.32, n.4, p.1069-1070, 1992.

BATHIA, V. S.; MANGLIK, P.; BRATNAGAR, P. S.; GURUPRASAD, K. N. Variation in sensitivity of genotypes to varying photoperiods in India. Soybean Genetics Newsletter, v.24, p.99-9103, 1997.

BILLORE, S. D.; JOSHI, O. P. Genotypical variability for yield and quality in Glycine max (L.) Merrill. Soybean Genetics Newsletter, v.24, p.88-91, 1997.

BONATO, E. R. Herança do tempo para o florescimento e para a maturidade em variantes naturais de soja [Glycine $\max$ (L.) Merrill]. Piracicaba, 1989. 166p. Tese (Doutorado) Escola Superior de Agricultura "Luiz de Queiroz" - Universidade de São Paulo.

BROWSE, J.; SOMERVILLE, C. Glycerolipid synthesis: biochemistry and regulation. Annual Review of Plant Physiology and Plant Molecular Biology, v.42, p.467-506, 1991.

BRUMMER, E. C.; GRAEF, G. L.; ORF, J.; WILCOX, J. R.; SHOEMAKER, R. C. Mapping QTL for seed protein and oil content in eight soybean populations. Crop Science, v.37, n.2, p.370-378, 1997.

BRUNO, J. Prospecting soybean disease fungi in Northeast of Buenos Aires, Argentina. Soybean Genetics Newsletter, v.24, p.29-31, 1997.

BURTON, J. W.; BRIM, C. A. Recurrent selection in soybean. III. Selection for increased percent oil in seed. Crop Science, v.21, n.1, p.31-34, 1981.

BURTON, J. W.; WISON, R. F.; BRIM, C. A. Recurrent selection in soybean. IV. Selection for increased oleic acid percentage in seed oil. Crop Science, v.23, n.4, p.744-747, 1983.

BUTON, J. W. Quantitative Genetics: results relevant to soybean breeding. In: WILCOX, J. R. Soybean: improvement, production, and uses. Madison: 1987. cap.6, p.211-247.

CARVALHO, S. P. Métodos alternativos de estimação de coeficiente de trilha e índice de seleção, sob multicolinearidade. Viçosa, 1995. 163p. Tese (D. S) - Universidade Federal de Viçosa.

CASTRO, P. R. C. Fisiologia da maturação e síntese de óleo e proteína na soja. In: CÂMARA, G. M.S. Soja: tecnologia da produção. Piracicaba: Publique, 1998. cap.6, p.74-83.

CHEIKH, N.; BRENNER, M. L. Regulation of key enzymes of sucrose biosynthesis in soybean leaves. Plant Physiology, v.100, p.1230-1237, 1992.

COLNAGO, L. A.. Análise do teor de óleo em sementes por NMR. São Carlos: EMBRAPA CNPDIA, 1996. 14p. (Circular Técnica, 3). 
CRUZ, C. D.; CASTOLDI, F. Decomposição da interação genótipos $x$ ambientes em partes simples e complexa. Revista Ceres, v.38, p.422-430, 1991.

CRUZ, C. D.; REGAZZI, A. J. Modelos biométricos aplicados ao melhoramento genético. Viçosa: Imprensa Universitária, 1997.390p.

CRUZ, C. D.; SEDIYAMA, C. S.; SEDIYAMA, T. Avaliação da capacidade combinatória e dos efeitos recíprocos em cultivares de soja. In: SEMINÁRIO NACIONAL DE PESQUISA DE SOJA, 3., Campinas, 1984. Anais. Campinas: CNPSo/EMBRAPA, 1984. p.485-492.

DOUBLER, T. W.; SUTTNER, B.; CHANG, S. J. C.; GIBSON, P. T.; LIGHTFOOT, D. A. Qualitative inheritance of quantitative trait loci. Soybean Genetics Newsletter, v.24, p.139$141,1997$.

ERICKSON, E. A.; WILCOX, J. R.; CAVINS, J. F. Fatty acid composition of the oil in reciprocal crosses among soybean mutants. Crop Science, v.28, n.4, p.644646, 1988.

FEHR, W. R.; CAVINNES, C. E. Stages of soybean development. Ames: Iowa State University, Ames, 1977. 12p. (Special Report, 80).

FERREIRA, M. E.; GRATTAPAGLIA, D. Introdução ao uso de marcadores RAPD e RFLP em análise genética. Brasilia: EMBRAPA / CENARGEN, 1995. 220p.

FREIRE FILHO, F. R. Análise genética de um dialelo entre genótipos precoces de soja [Glycine max (L.) Merrill]. Piracicaba, 1988. 224p. Tese (Doutorado) Escola Superior de Agricultura "Luiz de Queiroz" - Universidade de São Paulo.

GAI, J.; YOU, M. Genetics of quantitative traits of soybeans. In: WORLD SOYBEAN RESEARCH CONFERENCE, 5. Chiang Mai, 1994. p.28.

GARDNER, C. O.; EBERHART, S. A. Analysis and interpretation of the variety cross diallel and related populations. Biometrics, v.22, p.439-452, 1966.

GAUCH JUNIOR, H. G.; ZOBEL, R. W. AMMI analysis of yield triats: In: KANG, M. S.; GAUCH JUNIOR, H. G. Genotype-by-enviroment interaction. Boca Raton: CRC Press, 1996. cap. 1, p.1-14.

GERALDI, I. O.; MIRANDA FILHO, J. B. Adapted models for the analysis of combining ability for varieties in partial crosses. Revista Brasileira de Genética, v.11, n.2, p.419-430, 1988.

GERMPLASM RESOURCES INFORMATION NETWORK (GRIN). SoyBase. National Plant Germplasm System (NPGS). http://www.ars-grin.gov/npgs/[Home page] (10/1998)

GILIOLI, J. L.; SEDIYAMA, T.; FONSECA JUNIOR, N. Herança do número de dias para a floração em quatro mutantes naturais em soja, estudada sob condições de dias curtos. In: SEMINÁRIO NACIONAL DE PESQUISA DE SOJA, 3., Campinas, 1984. Anais. Campinas: CNPSo/EMBRAPA, 1984. p.323-337.

GIZLICE, Z.; CARTER JUNIOR, T. E.; BURTON, J. W. Genetic diversity in North American soybean I. Multivariate analysis of founding stock and relation to coefficient of parentage. Crop Science, v.33, p.614-0620, 1993.

GRAEF, G. L.; FEHR, W. R.; HAMMOND, E. G. Inheritance of three stearic acid mutants of soybean. Crop Science, v.25, n.6, p.1076-1079, 1985.

GRIFFING, B. Concept of general and especific combining in relation to diallel crossing systems. Australian Journal Biology Science, v.9, p.463-493, 1956. 
GUANGYU, Y.; HUIYU, Z.; CHUNFENG, H.; FENG, J. A preliminary study on protein and oil contents of wild soybean (G. soja) in Jilin province. Soybean Genetics Newsletter, v.20, p.35-38. 1993.

HANDEL, C. L.; MILACK, S. C. K.; FEDERIZZI, L. C. Riscos e benefícios do uso de plantas transgênicas na agricultura. Ciência Rural, v.26, n.3, p.511-517, 1996.

HANSON, W. D. Seed protein content and delivery of assimilates to soybean seed embryos. Crop Science, v.31, p.1600-1604, 1991.

HARTWIG, E. E.; COLLINS, F. I. Evaluation of density classifications as a selection technique in breeding soybeans for protein or oil. Crop Science, v.2, p.159-162, 1962.

HARTWIG, E. E.; LAMBERT, L.; KILEN, T. C. Registration of Lamar soybean. Crop Science, v.30, n.1, p.231, 1990.

HAYMAN, B. I. The theory and analysis of diallel crosses. Genetics, v.39, p.789-809, 1954.

HIROMOTO, D. M. Seleção de genótipos de soja para performance agronômica e resistência a Heterodera glycine Ichinohe e Diaporthe phaseolorum f. sp. meridionalis Morgan - Jones. Piracicaba, 1996. 84p. Tese (Doutorado) - Escola Superior de Agricultura “Luiz de Queiroz", Universidade de São Paulo.

HYMOWITZ, T.; SINGH, R. J.; KOLLIPARA, K. P. Biosystematics of the genus Glycine, 1996. Soybean Genetics Newsletter, v.24, p.119-120, 1997.

KINNEY, A. J. Genetic modification of the storage lipids of plants. Current Opinion in Biotechnology, v.5, n.5, p.144-151, 1994.

KISHA, T. J.; DIERS, B. D. Allelo contribution of parents to selected progeny from two-way crosses. Soybean Genetics Newsletter, v.24, p.190-193, 1997.

LAÍNEZ-MEJÍA, J. R. Implicações da interação genótipos $x$ ambientes na seleção de progenies de soja com enfese nas produtividades de grãos e 6leo. Piracicaba, 1996. 145p. Tese (Doutorado) - Escola Superior de Agricultura "Luiz de Queiroz", Universidade de São Paulo.

LARK, K. G.; CHASE, K.; ADLER, F.; MANSUR, L. M.; ORF, J. H. Interactions between quantitative trait loci in soybean in which trait variation at one locus is conditional upon a specific allele at another. Proceeding National Academic Science, v.92, n.10, p.4656-4660, 1995.

LEE, S. H.; BAILEY, M. A.; MIAN, M. A. R.; CARTER Jr, T. E.; SHIPE, E. R.; ASHLEY, D. A.; PARROTT, W. A.; HUSSEY, R. S.; BOERMA, H. R. RFLP loci associated with soybean seed protein and oil content across populations and locations. Theoretical and Applied Genetics, v.93, n.5-6, p.649-657, 1996.

LEFFEL, R. C. Economic models and breeding strategies for soybean improvement. Journal Production Agriculture, v.3, n.4, p.582-586, 1990.

LEFFEL, R. C.; RHODES, W. K. Agronomic performance and economic value of high-seedprotein soybean. Journal Agricultural, v.6, n.3, p.365-368, 1993.

MANJARREZ-SANDOVAL, P.; CARTER JUNIOR, T. E.; WEBB, D. M.; BURTON, J. W. Coefficent of parentage and RFLP markers: Are they useful in predicting genetic variance in soybean populations?. Soybean Genetics Newsletter, v. 23, p.197-202, 1996. 
MANSUR L. M.; LARK, K. G.; KROSS, H.; OLIVEIRA, A. Interval mapping of quantitative trait loci reproductive, morphological, and seed traits of soybean (Glycine max L.). Theoretical and Applied Genetics, v.86, n.8, p.907-913, 1993.

MARIOTTI, J. A. La interacción genotipo-ambiente, su significado e importancia en el mejoramiento genético y en la evaluación de cultivares. INTA-CRTS, Serie Monográfica $\mathrm{N}^{\circ}$ 1, 1994, 37p.

MEHETRE, S. S.; MAHAJAN, C. R.; GHATGE, R. D.; DHUMAL, P. M. Variability, heritability, path analysis and genetic divergence in soybean. In: WORLD SOYBEAN RESEARCH CONFERENCE, 5. Chiang Mai, 1994. p.77.

MEHETRE, S. S.; MAHAJAN, C. R.; SHINDE, R. B.; DHUMAL, P. M. Gamma ray induced high oil content in soybean (Glycine $\max$ (L.) Merrill.). Soybean Genetics Newsletter, v.23, p.98-101, 1996.

MIRANDA, M. A. C. DE; SUASSUNA FILHO, J.; BULASANI, E. A.; MASCARENHAS, H. A. A.; TISSELLI FILHO, O.; BRAGA, N. R. Efeito maternal e do genótipo sobre o teor de óleo e tamanho de sementes $F_{1}$ de soja. In: SEMINÁRIO NACIONAL DE PESQUISA DE SOJA, 3., Campinas, 1984. Anais. Campinas: CNPSo/EMBRAPA, 1984. p.309-317.

MIRANDA FILHO, J. B.; CHAVES, L. J. Analysis os diallel crosses with $\mathrm{F}_{2}$ generations. Revista Brasileira de Genética, v.19, n.1, p.127-132, 1996.

MIRANDA FILHO, J. B.; GERALDI, I. O. An adapted model for the analysis of partial diallel crosses. Revista Brasileira de Genética, v.7, p.677-688, 1984.

MONTAÑO-VELASCO, J. C. Análise genética de progênies $F_{3}$ de soja derivadas de cruzamentos em cadeia com enfase na produtividade de 6́leo. Piracicaba, 1994. 115p. Tese (Doutorado) Escola Superior de Agricultura "Luiz de Queiroz" - Universidade de São Paulo.

MOORE, T. S. Lipid metabolism in plants. Boca Raton: CRC Press, 1993. 350p.

MOREIRA, M. A.; ABDELNOOR, R. V.; BARROS, E. G.; SEDIYAMA, C. S. Use of RAPD markers to evaluate genetic diversity among adapted cultivars of Brazilian soybean. In: WORLD SOYBEAN RESEARCH CONFERENCE, 5. Chiang Mai, 1994. p.9.

MOUNTS, T . L.; SNYDER, J. M.; HINSCH, R. T.; BONGERS, A. J.; CLASS, A. R. Quality of soybeans in export. Journal American Oil Chemists' Society, v.67, n.11, 1990.

MURPHY, D. J. The use of conventional and molecular genetics to produce new diversity in seed oil composition for the use of plant breeders-progress, problems and future prospecs. Euphytica, v.85, n.1-3, p.433-440, 1995.

PALUDZYSZYN, F. E.; MIRANDA FILHO, J. B. Análise do potencial genético de cultivares de soja (Glycine $\max (\mathrm{L}$.) Merrill através de cruzamentos dialélicos. Relatorio Técnico, Departamento de Genética, ESALQ/USP, Piracicaba, p.125-134, 1981.

PORTO, M. P.; VERNETTI, F de J. Parcelas de covas e de fileiras na avaliação do rendimento e de outras características agronômicas de tres cultivares de soja (Glycine max (L.) Merrill). In: SEMINÁRIO NACIONAL DE PESQUISA DE SOJA, 2., Campinas, 1981. Anais. Campinas: CNPSo/EMBRAPA, 1981. p.489-499.

PRESCOTT-ALLEN, R. C. Genes from the wild. London: Earthscan Publications LTD, 1988. 111p.

QI, Y.; JINLING, W. The combining ability analysis for three different types of soybean and their generation. In: WORLD SOYBEAN RESEARCH CONFERENCE, 5., 1994. p.45. 
QUI, X. B.; RAO ARELLI, A. P.; SLEPER, D. A. RLFP markers associated with soybean oil and protein concentration. Soybean Genetics Newsletter, v.24, p.206-207, 1997.

RASMUSSON, D. C.; PHILLIPS, R. L. Plant breeding progress and diversity from de novo variation and elevated epistasis. Crop Science, v.37, n.2, p.303-310, 1997.

REUNIÓN ANUAL DEL SUBPROGRAMA SOJA, Villa Carlos Paz, 1994. Perspectivas mundiales del complajo soja en el mediano plazo. Novitas S. A. 26p.

ROCHA, M. de M. Interação genótipos x locais em linhagens experimentais de soja com diferentes ciclos de maturação. Piracicaba, 1998. 98p. Dissertação (Mestrado) Escola Superior de Agricultura "Luiz de Queiroz" - Universidade de São Paulo.

SAS Institute Inc. SAS User's Guid: Statistical, version 6.11 edition. Cary, NC: SAS Institute Inc., 1996. 956p.

SING, B. B.; HADLEY, H. H. Maternal control of oil synthesis in soybeans, Glycine max (L.) Merr. Crop Science, v.8, p.622-625, 1968.

SINCLAIR, J. B. Reducing losses from plant diseases. In: WORLD SOYBEAN RESEARCH CONFERENCE, 5. Chiang Mai, 1994. p.10.

SOLDINI, D. O. Interação genotipos $\times$ locais e correlações entre caracteres com enfase na produtividade de oleo em soja. Piracicaba, 1993. 136p. Dissertação (Mestrado) Escola Superior de Agricultura "Luiz de Queiroz" - Universidade de São Paulo.

SPECHT, J. E.; GRAEF, G. L. Limitations and potentials of genetic manipulation of soybean. In: VERMA, D. P. S.; SHOEMAKER, R. C. Soybean: genetics, molecular biology and biotechnology. CAB International, 1996. cap.5, p.270.

STEEL , R. G. D; TORRIE, J. H. Bioestadística: principios y procedimientos. México: McGrau Hill, 1985. 622p.

TAWARE, S. P.; HALVANKAR, G. B.; RAUT, V. M.; PATIL, V. P. Variability, correlation and path analysis in soybean hybrids. Soybean Genetics Newsletter, v.24, p.96-98, 1997.

TEDXEIRA, J. P. F.; RAMOS, M. T. B.; MIRANDA, M. A. C.; MASCARENHAS, H. A. A. Relação entre os principais constituintes químicos de grãos de soja. In: SEMINÁRIO NACIONAL DE PESQUISA DE SOJA, 3., Campinas, 1984. Anais. Campinas: CNPSo/EMBRAPA, 1984. p.899-908.

TERRY, I.; ELLISON, R.; WOOLSTENHULME, L.; JAGAR, A.; ALLEN, B,; BARTON, J.; CORNELI, P.; CORNIA, R.; FULLER, D.; GOWANS, M.; HALL, M.; HEATON, W.; HOWARD, J.; NIELSEN, B.; PERRY, S.; RICHARDS, R.; SEXTON, J.; THOMPSON, D.; TROY, J. D.; WEBER, A.; WELLS, B.; WOOD, S.; WRIGHT, D. Molecular phylogeny as a tool for soybean breeding IV. Soybean Genetics Newsletter, v.22, p.251-259, 1995.

TOLEDO, J. F. F.; GILIOLI, J. L. Tamanho mínimo de amostra para estimar a média e a variância de dois tipos de populaçð̃es de soja. In: SEMINÁRIO NACIONAL DE PESQUISA DE SOJA, 2., Campinas, 1981. Anais. Campinas: CNPSo/EMBRAPA, 1981. p.500-521.

UNIVERSIDADE FEDERAL DE VIÇOSA. Departamento de Biologia Geral. Programa GENES ${ }^{\circledR}$ Versão 96.1: Aplicativo computacional em genética e estatística (software). UFV, 1997. 442p. +2 disquetes.

UPDAW, N. J.; NICHOLS, JR. Pricing soybeans on the basis of chemical constituents. In: WORLD SOYBEAN RESEARCH CONFERENCE, 2. Danville: Interstate prinrs \& publishers, INC, 1979. p.781-799. 
VAN RAAMSDONK, L. W. D. The cytological and genetical mechanisms of plant domestication exemplified by four crop models. Botanic Review, v.61, p.367-399, 1995.

VELLO, N. A.; HIROMOTO, D. M.; AZEVEDO FILHO, A. J. B. V. Coefficient of parentage and breeding of Brazilian soybean germoplasm. Revista Brasileira de Genética, v.11, n.3, p.679-697, 1988.

VELLO, N. A.; HIROMOTO, D. M.; YORINORI, J. T.; FERREIRA, B. M.; BOOTAN, A. J.; KIIHL, R. A. S. USP 01 a USP11: novas linhagens de soja resistentes ao nematóide de cisto, cancro da haste, mancha olho-de-rã. Revista Brasileira de Genética, v.17, p.362, 1994. Suplemento apresentado ao $40^{\circ}$ Congresso Nacional de Genética, Caxambu, 1994 - Resumo.

VERMA, D. P. S.; SHOEMAKER, R. C. Soybean: genetics, molecular biology and biotechnology. Wallingford: CAB International, 1996. 270p.

VIANA, J. M. S. Teoria e análise de cruzamentos dialélicos parciais, com aplicação no melhoramento genético do feijoeiro (Phaseolus vulgaris L.). Viçosa, 1994. 100p. Tese (D. S) Universidade Federal de Viçosa.

WALLACE, D. H.; BAUDOIN, J. P.; BEAVER, J.; COYNE, D. P.; HALSETH, D. E.; MASAYA, P. M.; MUNGER, H. M.; MYERS, J. R.; SILBERNAGEL, M.; YOURSTONE, K. S.; ZOBEL, R. W. Improving efficiency of breeding for higher crop yield. Theoretical and Applied Genetics, v.86, p.27-40, 1993.

WILCOX, J. R. Breeding soybeans for improvement of oil quantity and quality. In: WORLD SOYBEAN RESEARCH CONFERENCE, 3. Ames: Westview Press, 1985. p.380-386.

YORINORI, J. T. Controle integrado das principais doenças de soja. In: CÂMARA, G. M. S. Soja: tecnologia da produção. Piracicaba: Publique, 1998. cap.10, p.139-192.

ZHIHONG, H.; ZHENCHUN, Y.; YONGHUA, X.; HONG, L. The eco-geographical distribution of chemical quality of G. soja. In: WORLD SOYBEAN RESEARCH CONFERENCE, 4. Buenos Aires: Editora S. R. L., 1989. p.129-134. 
T A BELAS 


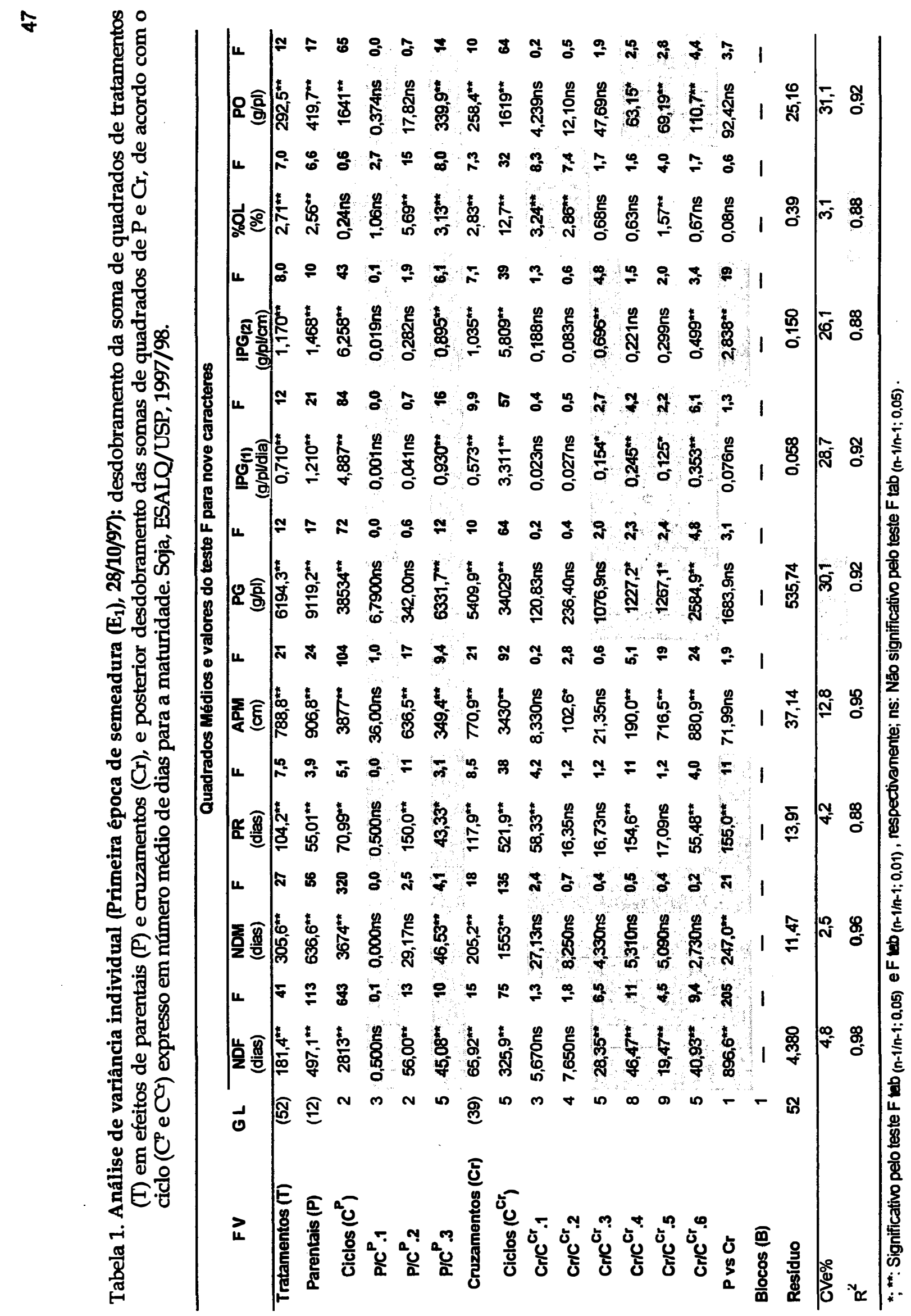


q

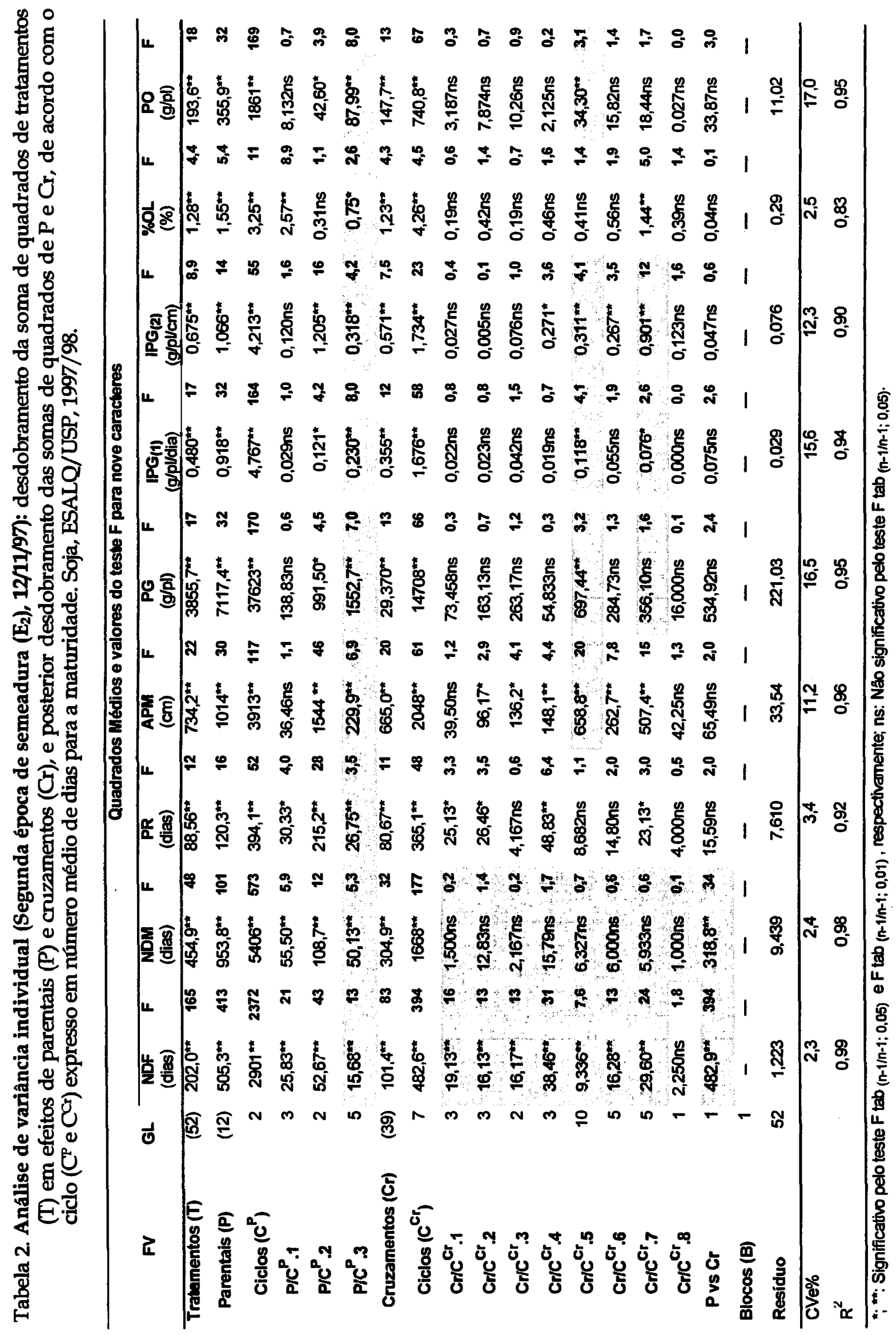




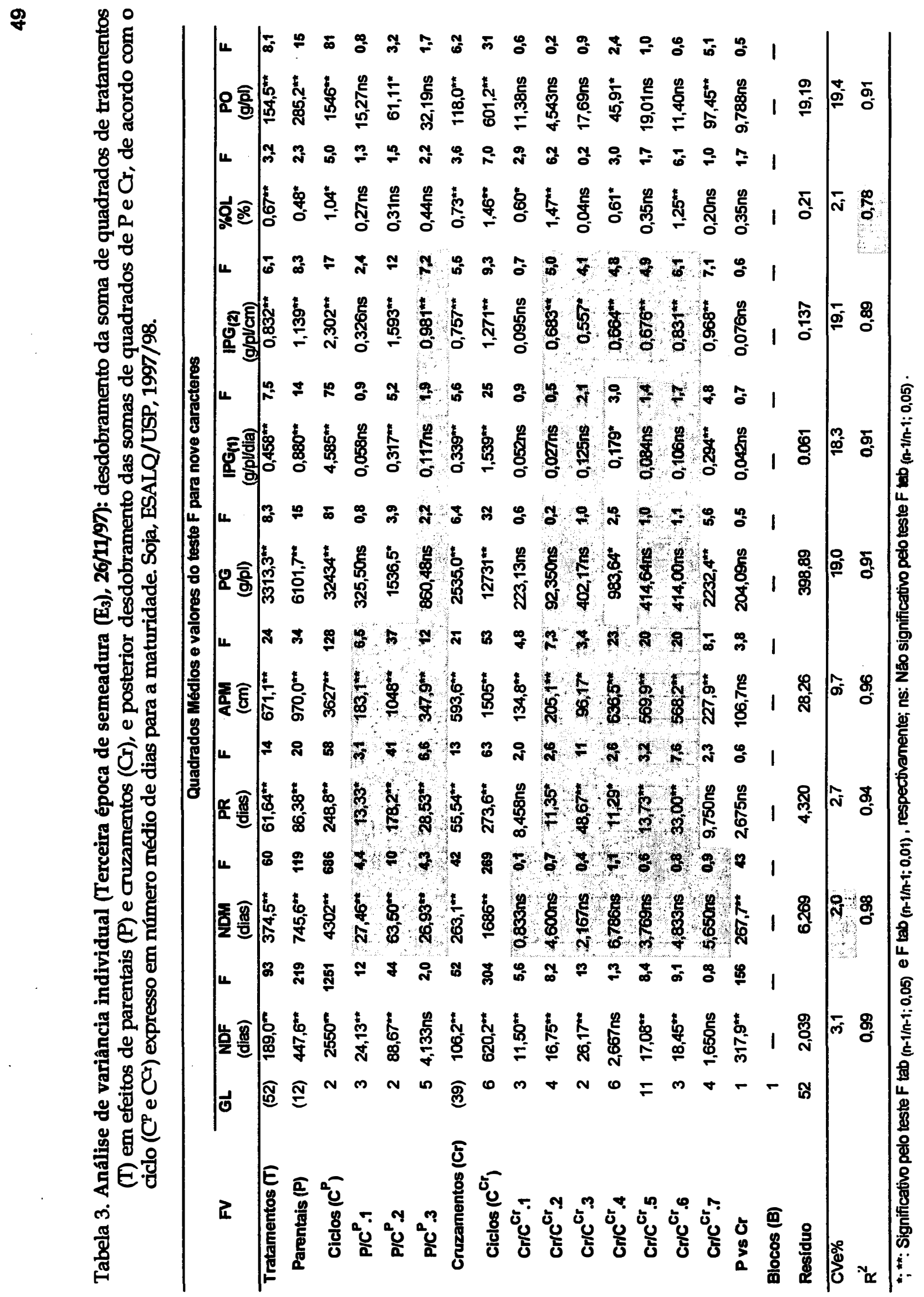



4 두 1 क

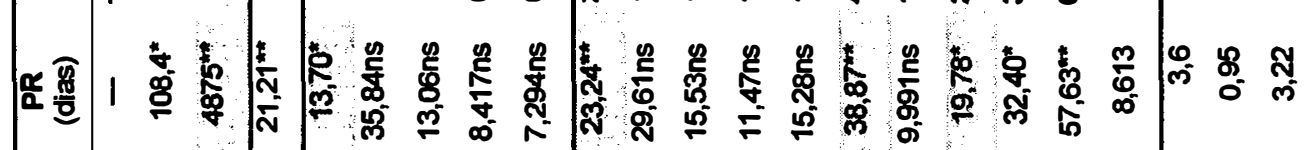

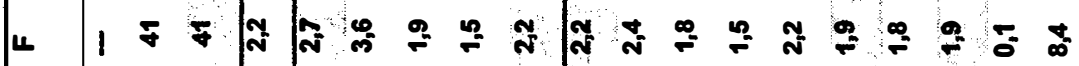

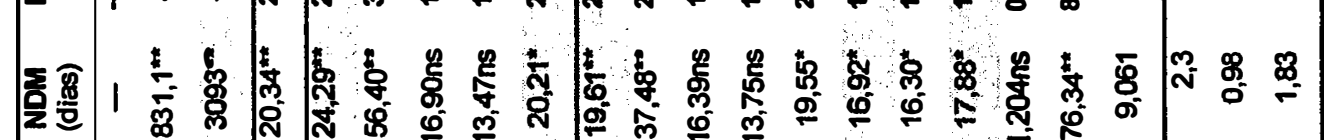

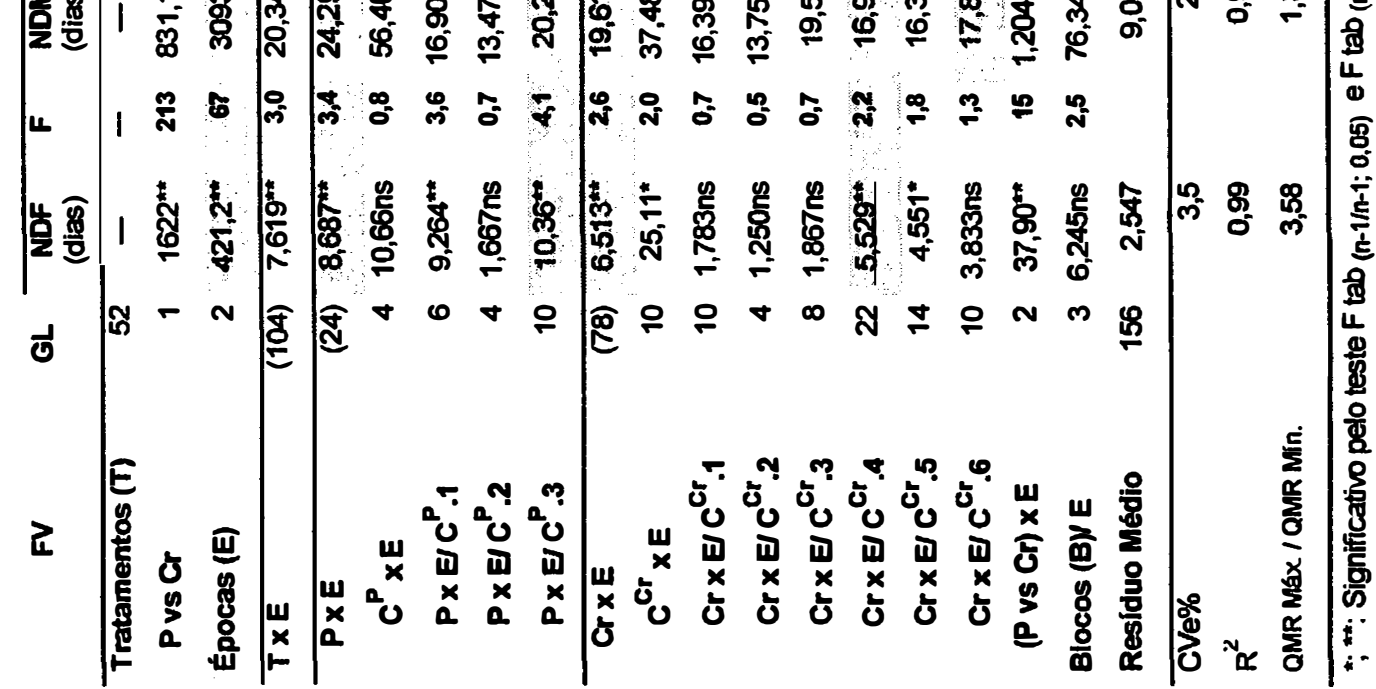


Tabela 5. Interação genótipos $\times$ épocas de semeaduras ( $\mathbf{G} \times$ pares $E$ ): decomposição em parte complexa (\%PC) (acima da diagonal) e simples (\%PS) (abaixo da diagonal) e estratificação" (agrupamento) de épocas de semeaduras (E), para nove caracteres. Soja, ESALQ/USP, 1997/98.

\begin{tabular}{|c|c|c|c|c|c|c|c|c|c|}
\hline & & $\begin{array}{l}\text { NDF } \\
\text { (dias) }\end{array}$ & & & $\begin{array}{l}\text { NDM } \\
\text { (dias) }\end{array}$ & & & $\begin{array}{c}\text { PR } \\
\text { (dias) }\end{array}$ & \\
\hline Épocas & $E_{1}$ & $E_{2}$ & $E_{3}$ & $E_{1}$ & $E_{2}$ & $E_{3}$ & $E_{1}$ & $E_{2}$ & $E_{3}$ \\
\hline$E_{1}$ & & $\overline{19,6}$ & 23,7 & & 17,0 & 23,3 & & 52,4 & 51,6 \\
\hline$E_{2}$ & 80,4 & & 13,9 & 83,0 & & 11,4 & 47,6 & & 24,3 \\
\hline$E_{3}$ & 76,3 & 86,1 & & 76,7 & 88,6 & & 48,4 & 75,7 & \\
\hline Agrup. & & & & & $E_{2}, E_{3}$ & & & $E_{2}, E_{3}$ & \\
\hline
\end{tabular}

\begin{tabular}{|c|c|c|c|c|c|c|c|c|c|}
\hline & & $\begin{array}{l}\text { APM } \\
(\mathrm{cm})\end{array}$ & & & $\begin{array}{l}\text { PG } \\
\text { (g/pl) }\end{array}$ & & & $\begin{array}{c}\mathrm{IPG}_{(1)} \\
\text { (g/pl/dias) }\end{array}$ & \\
\hline Epocas & $E_{1}$ & $E_{2}$ & $E_{3}$ & $E_{1}$ & $E_{2}$ & $E_{3}$ & $E_{1}$ & $E_{2}$ & $E_{3}$ \\
\hline$\overline{E_{1}}$ & & 31,0 & 30,2 & & 37,8 & 44,4 & & 38,4 & 46,8 \\
\hline$E_{2}$ & 69,0 & & 16,5 & 62,2 & & 35,4 & 61,6 & & 39,1 \\
\hline$E_{3}$ & 69,8 & 83,5 & & 55,6 & 64,6 & & 53,2 & 60,9 & \\
\hline Agrup. & & $E_{2}, E_{3}$ & & & $E_{2}, E_{3}$ & & & & \\
\hline
\end{tabular}

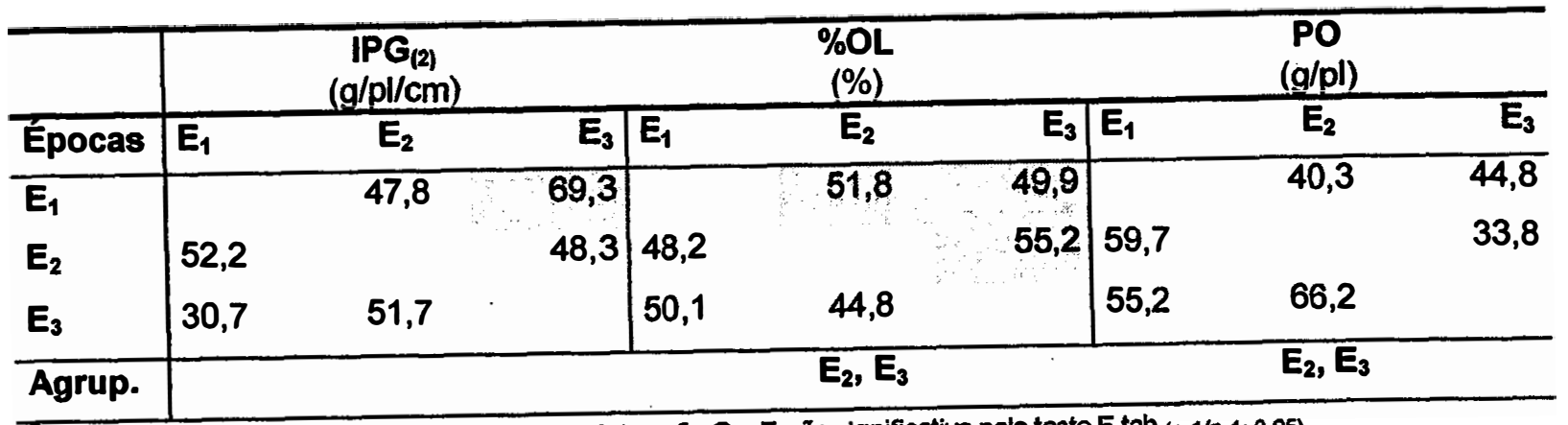

": Agrupamento de épocas de semeaduras com interaçáo $\mathbf{G}$ x E nåo significativa pelo teste $F$ tab $(n-1 / n-1 ; 0,05)$. 
Tabela 6. Médias e limites de variação (Primeira época de semeadura ( $\left.\left.E_{1}\right), 28 / 10 / 97\right)$ : parentais $(P)$ e cruzamentos $(\mathrm{Cr})$ agrupados em ciclos $\left(\mathrm{C}^{\mathrm{P}}\right.$ e $\left.\mathrm{C}^{\mathrm{Cr}}\right)$, expressos em número médio de dias para a maturidade. Soja, ESALQ/USP, 1997/98.

\begin{tabular}{|c|c|c|c|c|c|c|c|c|c|c|c|}
\hline & & & $\begin{array}{l}\text { NDF } \\
\text { (dias) }\end{array}$ & $\begin{array}{l}\text { NDM } \\
\text { (dias) }\end{array}$ & $\begin{array}{c}\text { PR } \\
\text { (dias) } \\
\end{array}$ & $\begin{array}{l}\text { APM } \\
(\mathrm{cm})\end{array}$ & $\begin{array}{c}\text { PG } \\
(g / p l)\end{array}$ & $\begin{array}{c}\mathbf{I P G}_{(\mathbf{1})} \\
(\mathrm{g} / \mathrm{p} / \mathrm{dia})\end{array}$ & $\begin{array}{c}\mathbf{I P G}(\mathbf{2}) \\
(\mathrm{g} / \mathrm{pl} / \mathrm{cm})\end{array}$ & $\begin{array}{c}\% O L \\
(\%) \\
\end{array}$ & $\begin{array}{c}\text { PO } \\
\text { (g/pl) }\end{array}$ \\
\hline & & $\mathbf{N}$ & \multicolumn{9}{|c|}{ Médias de 24 observaçб̋es (12 plantas / parcela $x 2$ repetiçøes) para nove caracteres } \\
\hline & $c^{P} \cdot 1$ & 4 & 32,8 & 117,0 & 84,3 & 28,0 & 8,1 & 0,10 & 0,30 & 20,2 & 1,7 \\
\hline & & & $32-33$ & $117-117$ & $84-85$ & $25-38$ & $6-11$ & $0,07-0,10$ & $0,21-3,20$ & $19,3-21,0$ & $1,2-2,2$ \\
\hline \multirow[t]{4}{*}{ Parentais } & $c^{P} .2$ & 3 & 38,9 & 126,8 & 87,9 & 41,4 & 37,0 & 0,42 & 0,94 & 20,6 & 7,7 \\
\hline & & & $33-43$ & $124-131$ & $83-98$ & $29-62$ & $22-46$ & $0,27-0,56$ & $0,69-1,38$ & $19,4-22,5$ & $4,3-9,7$ \\
\hline & $C^{P} .3$ & 6 & 64,6 & 154,1 & 89,5 & 66,9 & 127,6 & 1,44 & 1,88 & 20,4 & 26,4 \\
\hline & 3 & 13 & $60-70$ & $145-160$ & 8497 & $51-92$ & $80-202$ & $0,85-2,42$ & $1,44-3,14$ & $18,4-21,7$ & $15,7-43,4$ \\
\hline \multicolumn{3}{|c|}{ Média ponderada } & 48,9 & 136,4 & 87,5 & 49,1 & 69,9 & 0,79 & 1,18 & 20,4 & 14,5 \\
\hline & $c^{c t} .1$ & 4 & 33,9 & 114,9 & 80,9 & 27,1 & 10,7 & 0,14 & 0,40 & 18,8 & 2,0 \\
\hline & & & $33-36$ & $110-117$ & $73-84$ & $25-29$ & $4-21$ & $0,05-0,29$ & $0,14-0,82$ & $17,1-20,0$ & $0,7-3,9$ \\
\hline & $\mathrm{c}^{\mathrm{Cr}} .2$ & 5 & 34,8 & 121,5 & 88,8 & 36,7 & 25,8 & 0,30 & 0,69 & 19,5 & 5,1 \\
\hline & & & $33-37$ & $119-124$ & $84-92$ & $26-43$ & $15-41$ & $0,17-0,44$ & $0,44-0,97$ & $18,2-21,4$ & $2,8-8,7$ \\
\hline & $\mathrm{c}^{\mathrm{Cr}} .3$ & 6 & 41,3 & 126,6 & 85,3 & 34,8 & 49,9 & 0,59 & 1,42 & 19,7 & 9,9 \\
\hline \multirow[t]{7}{*}{ Cruzam. } & & & $35-45$ & $125-129$ & $82-90$ & $31-39$ & $27-91$ & $0,30-1,07$ & $0,71-1,68$ & $18,9-21,5$ & $5,3-18,7$ \\
\hline & $\mathrm{c}^{\mathrm{Cr}} .4$ & 9 & 43,3 & 133,5 & 88,5 & 42,6 & 71,5 & 0,83 & 1,64 & 20,7 & 14,9 \\
\hline & & & $38-50$ & $131-135$ & $97-68$ & $30-59$ & $44-122$ & $0,46-1,46$ & $1,22-2,23$ & $20,1-22,0$ & $8,9-27,0$ \\
\hline & $c^{C r} .5$ & 10 & 45,3 & 140,8 & 95,5 & 55,5 & 111,4 & 1,16 & 2,09 & 21,2 & 23,7 \\
\hline & & & $41-49$ & $139-144$ & $92-100$ & $37-90$ & $85-170$ & $0,88-1,76$ & $1,58-2,88$ & $19,3-22,1$ & $16,3-36,8$ \\
\hline & $\mathrm{C}^{\mathrm{Cr}} .6$ & 6 & 47,3 & 146,1 & 98,8 & 74,9 & 156,6 & 1,60 & 2,18 & 21,5 & 33,7 \\
\hline & 6 & 40 & $41-53$ & $145-148$ & $92-107$ & $56-96$ & $123-220$ & $1,29-2,38$ & $1,69-2,87$ & $20,8-22,0$ & $25,7-46,2$ \\
\hline \multicolumn{3}{|c|}{ Média ponderada } & 42,1 & 132,8 & 90,4 & 47,2 & 79,2 & 0,85 & 1,56 & 20,4 & 16,7 \\
\hline \multirow{2}{*}{\multicolumn{3}{|c|}{$\begin{array}{l}\text { Média geral ponderada } \\
\text { Desvio padrão da média }\end{array}$}} & $43,8 \pm 1,9$ & $133,8 \pm 2,4$ & $89,7 \pm 1,5$ & $47,7 \pm 3,9$ & $76,9 \pm 11,3$ & $0,84 \pm 0,12$ & $1,47 \pm 0,16$ & $20,4 \pm 0,24$ & $16,1 \pm 2,47$ \\
\hline & & & 0,93 & 1,22 & 0,74 & 1,96 & 5,61 & 0,06 & 0,08 & 0,12 & 1,23 \\
\hline \multicolumn{3}{|c|}{ Quartil 3 (75\%) } & 48 & 144 & 95 & 60 & 110 & 1,25 & 2,10 & 21,3 & 22,7 \\
\hline \multicolumn{12}{|c|}{ Observaçōes de plantas individuais para nove caracteres } \\
\hline \multicolumn{3}{|l|}{ Máximo } & & & 117 & 120 & 434 & 4,53 & 6,94 & 26,2 & 97,7 \\
\hline \multicolumn{3}{|c|}{ Quartil 3 (75\%) } & & & 98 & 68 & 136 & 1,46 & 2,40 & 21,8 & 29,1 \\
\hline Medlana & & & & & 91 & 42 & 64 & 0,69 & 1,30 & 20,8 & 13,5 \\
\hline
\end{tabular}

: Intervalo de confiança da média pelo teste $t$ tab $(n-1 ; 0,05)$. 
Tabela 7. Médias e limites de variação (Segunda época de semeadura $\left.\left(E_{2}\right), 12 / 11 / 97\right)$ : parentais $(P)$ e cruzamentos $(\mathrm{Cr})$ agrupados em ciclos $\left(\mathrm{C}^{\mathrm{P}}\right.$ e $\left.\mathrm{C}^{\mathrm{Cr}}\right)$, expressos em número médio de dias para a maturidade. Soja, ESALQ/USP, 1997/98.

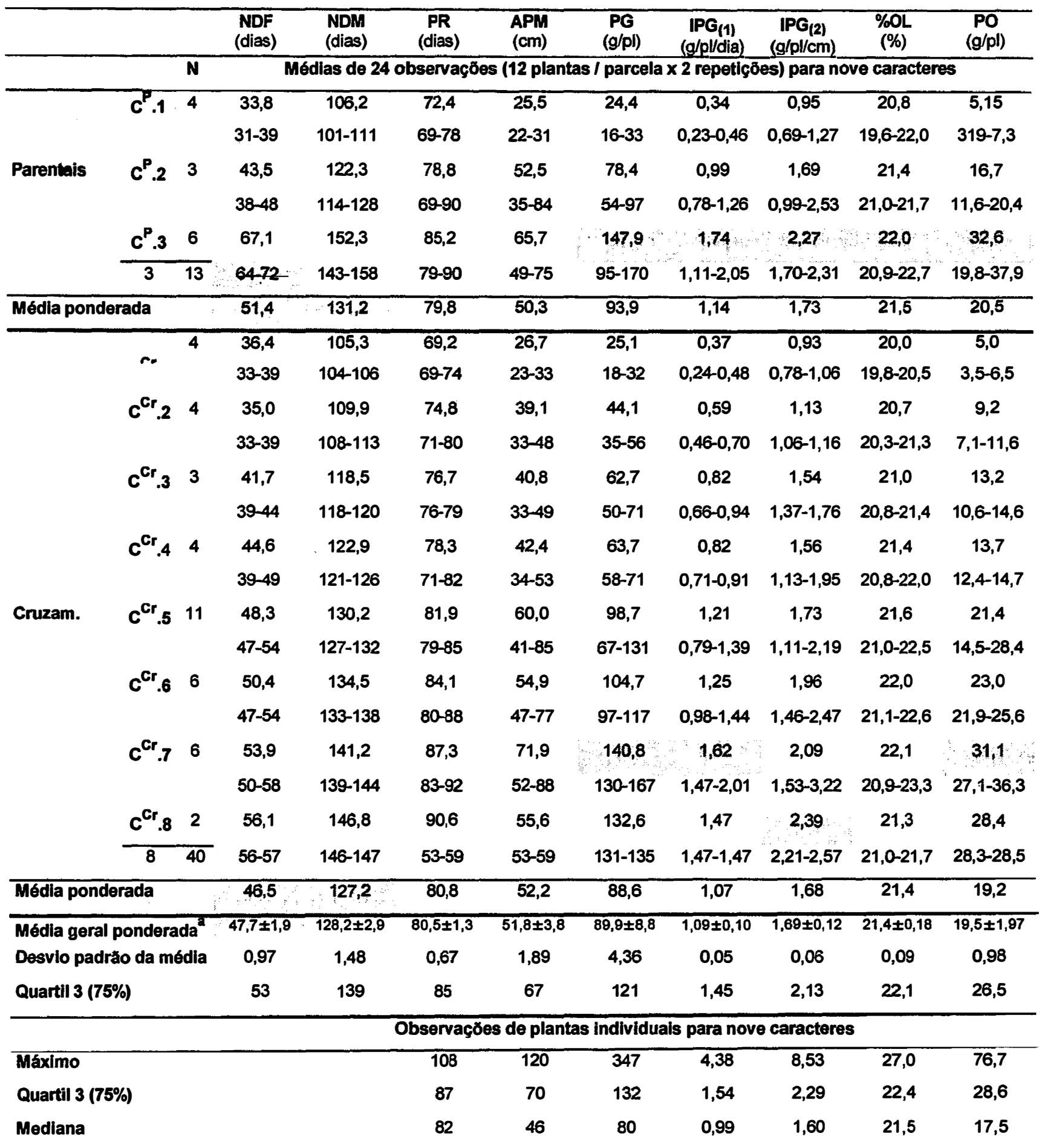

\footnotetext{
: Intervalo de confiança da média pelo teste $t$ tab $(n-1 ; 0,05)$.
} 
Tabela 8. Médias e limites de variação (Terceira época de semeadura (E $\left.\left.E_{3}\right), 26 / 11 / 97\right)$ : parentais (P) e cruzamentos $(\mathrm{Cr})$ agrupados em ciclos $\left(\mathrm{C}^{\mathrm{P}}\right.$ e $\left.\mathrm{C}^{\mathrm{Cr}}\right)$, expressos em número médio de dias para a maturidade. Soja, ESALQ/USP, 1997/98.

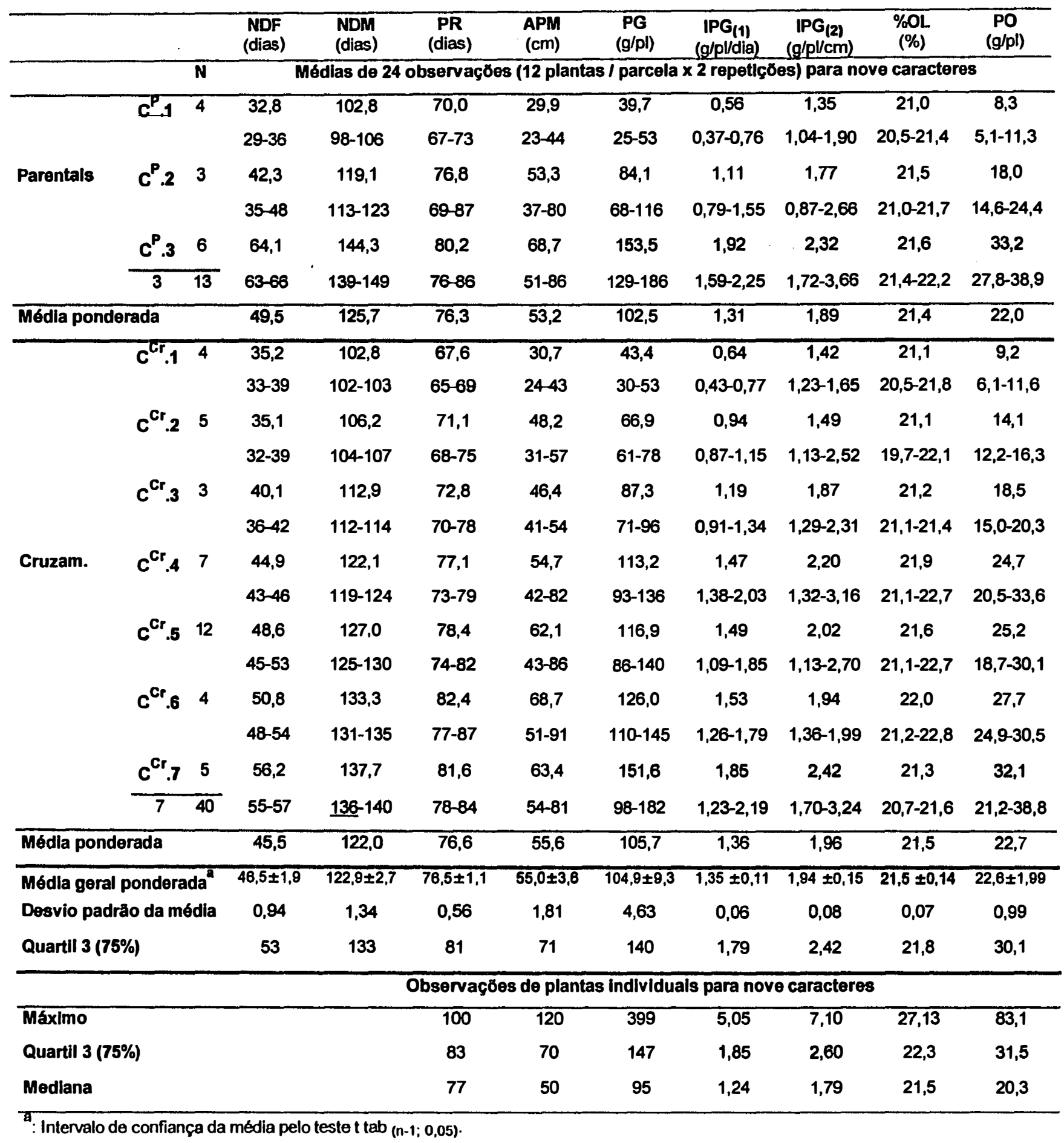




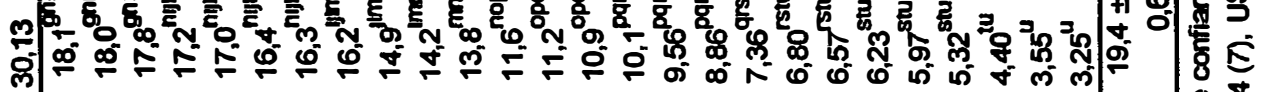

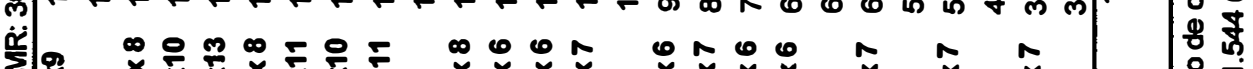

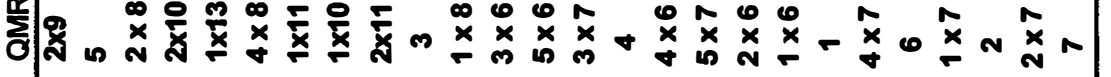

율

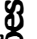

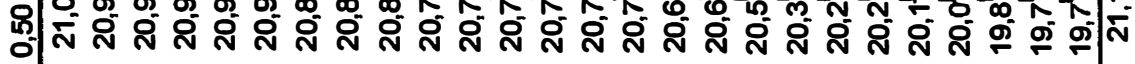

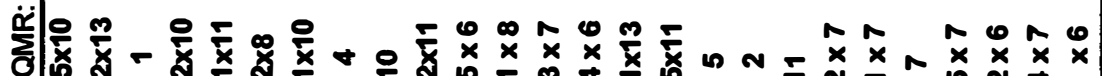

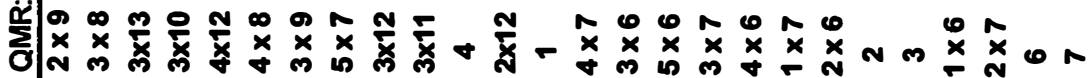
N E

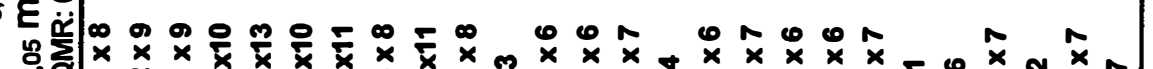
กั่ ஸิ

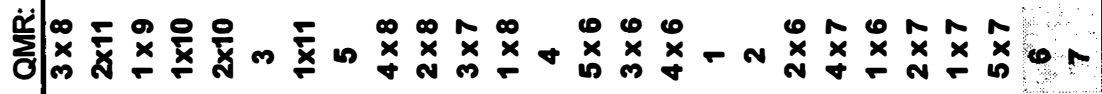


Tabela 10. Análise de correlações parciais com colinearidade\# entre variáveis: decomposição do coeficiente de correlação genética (rg) em efeitos genéticos diretos (EGD) e indiretos (EGI) dos caracteres explicativos sobre o caracteres principais. Soja, ESALQ/USP, $1997 / 98$.

\begin{tabular}{|c|c|c|c|c|c|}
\hline \multicolumn{3}{|c|}{ Caráter Principal PG } & \multicolumn{3}{|c|}{ Caráter Principal PO } \\
\hline $\begin{array}{l}\text { Caracteres } \\
\text { Expllcativos }\end{array}$ & Efeltos Genéticos & Estimativas & $\begin{array}{l}\text { Caracteres } \\
\text { Explicativos }\end{array}$ & Efeltos Genéticos & Estimativas \\
\hline \multirow[t]{5}{*}{ NDF } & EGD & 1,11 & \multirow[t]{5}{*}{ PR } & EGD & 0,05 \\
\hline & EGI via NDM & $-0,73$ & & EGI via PG & 0,49 \\
\hline & EGI via PR & 0,28 & & EGI via IPG(1) & 0,19 \\
\hline & EGI via APM & 0,22 & & EGI via \%OL & 0,04 \\
\hline & Total $(r g)$ & 0,88 & & Total (rg) & 0,77 \\
\hline \multirow[t]{5}{*}{ NDM } & EGD & $-0,78$ & \multirow[t]{5}{*}{$\overline{P G}$} & EGD & 0,64 \\
\hline & EGI via NDF & 1,03 & & EGI via PR & 0,04 \\
\hline & EGI via PR & 0,42 & & EGI via IPG(1) & 0,28 \\
\hline & EGI via APM & 0,27 & & EGI via \%OL & 0,04 \\
\hline & Total (rg) & 0,94 & & Total (rg) & 0,99 \\
\hline \multirow[t]{5}{*}{ PR } & EGD & 0,53 & \multirow[t]{5}{*}{$\mathbf{I P G}_{(1)}$} & EGD & 0,28 \\
\hline & EGI via NDF & 0,58 & & EGI via PR & 0,03 \\
\hline & EGI via NDM & $-0,61$ & & EGI via PG & 0,63 \\
\hline & EGI via APM & 0,27 & & EGI via \%OL & 0,04 \\
\hline & Total (rg) & 0,76 & & Total (rg) & 0,99 \\
\hline \multirow[t]{5}{*}{$\overline{A P M}$} & EGD & 0,35 & \multirow[t]{5}{*}{$\% O L$} & EGD & 0,05 \\
\hline & EGI via NDF & 0,68 & & EGI via PR & 0,04 \\
\hline & EGI via NDM & $-0,59$ & & EGI via PG & 0,47 \\
\hline & EGI via PR & 0,40 & & EGI via IPG(1) & 0,20 \\
\hline & Total (rg) & 0,85 & & Total $(r g)$ & 0,75 \\
\hline$R^{2}$ & & 0,94 & $R^{2}$ & & 0,99 \\
\hline Residuo & & 0,24 & Residuo & & 0,10 \\
\hline
\end{tabular}

\begin{tabular}{|c|c|c|c|c|c|}
\hline \multicolumn{3}{|c|}{ Caráter Principal IPG } & \multicolumn{3}{|c|}{ Caráter Principal IPG (2) } \\
\hline $\begin{array}{l}\text { Caracteres } \\
\text { Expllcativos }\end{array}$ & Efeltos Genéticos & Estimativas & $\begin{array}{l}\text { Caracteres } \\
\text { Explicativos }\end{array}$ & Efeltos Genéticos & Estimativas \\
\hline \multirow[t]{3}{*}{ PR } & EGD & $-0,16$ & APM & EGD & $-0,99$ \\
\hline & EGI via PG & 0,84 & & EGI via PG & 1,41 \\
\hline & Total (rg) & 0,68 & & Total (rg) & 0,42 \\
\hline \multirow[t]{3}{*}{$\overline{\mathbf{P G}}$} & EGD & 1,10 & PG & EGD & 1,67 \\
\hline & EGI via PR & $-0,12$ & & EGI via APM & $-0,84$ \\
\hline & Total $(r g)$ & 0,98 & & Total (rg) & 0,84 \\
\hline$\overline{R^{2}}$ & & 0,98 & $\mathbf{R}^{2}$ & & $\overline{0,98}$ \\
\hline Resíduo & & 0,14 & Resíduo & & 0,14 \\
\hline
\end{tabular}

\#. Para atenuar efeitos de multicolinearidade entre variáveis foi introduzida a constante $K=0,003846$ na diagonal da matriz $X^{\prime} X$. rg: Correlaçåo genética entre o caráter explicativo de EGD e o caráter principal. Os caracteres NDF, NDM, PR, APM, PG e \%OL foram transformados por $\log _{10}(x)$ e os caracteres IPG $(1), I G_{(2)}$ e PO por $\log _{10}(x+1)$. 
ณ

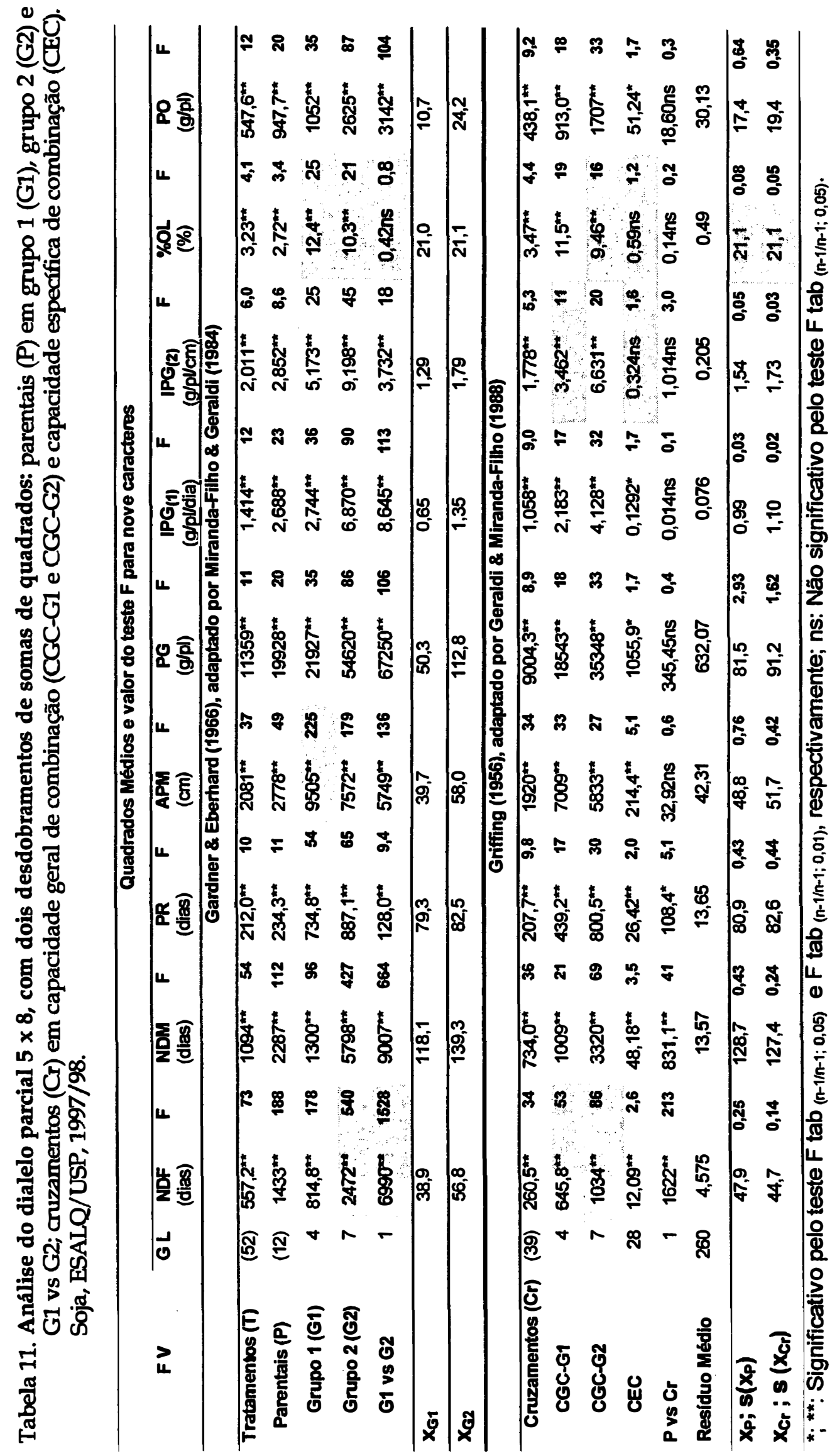




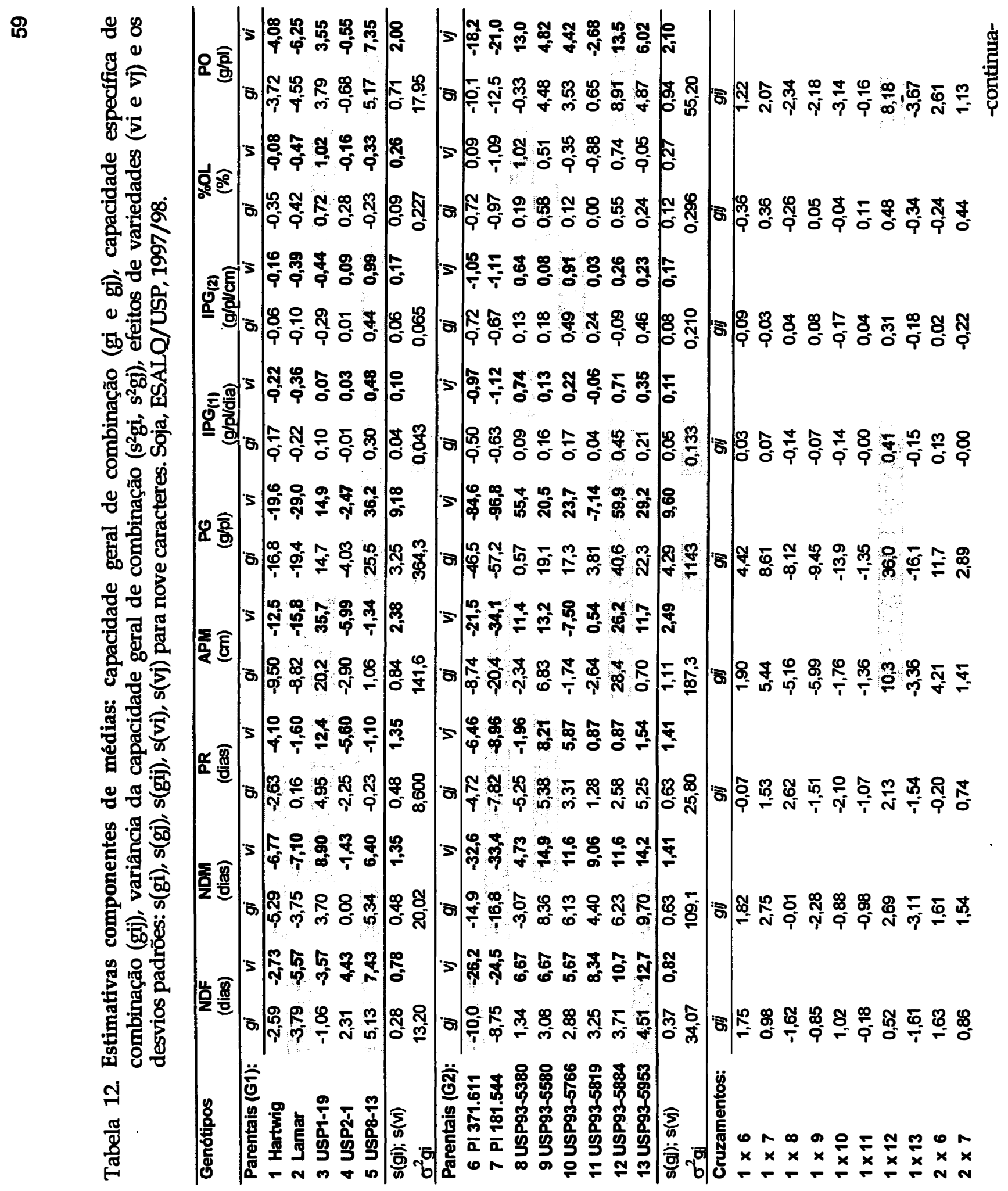


8

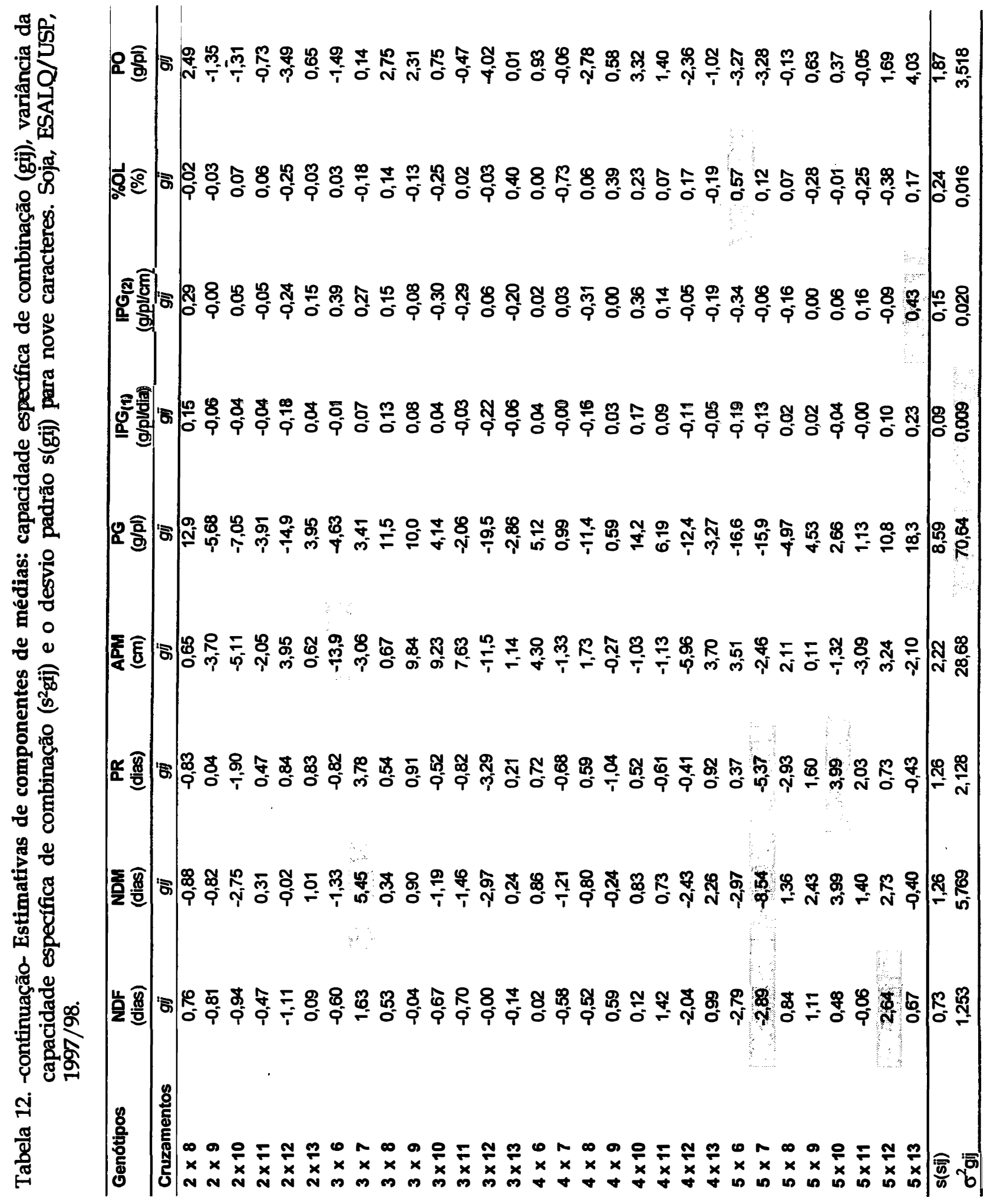


$\overline{0}$ ชั่

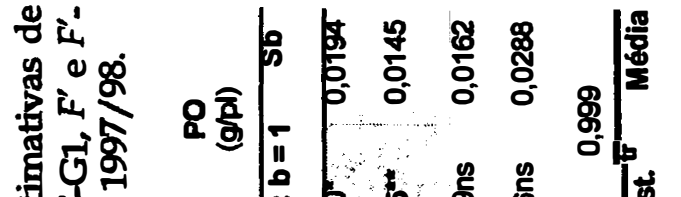

量䂞

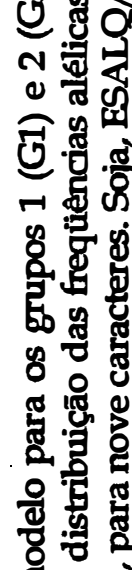

읨

웜 항

约

为

兽

。ํำ

政

is

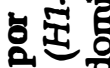

원

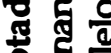

敋

잉

을

웅

동

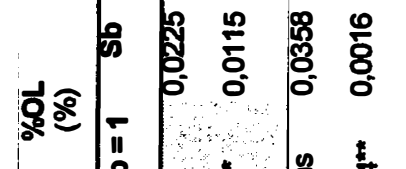

g

要

密

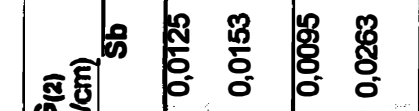

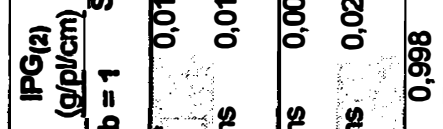

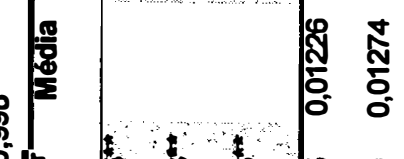

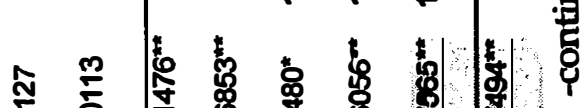

言总

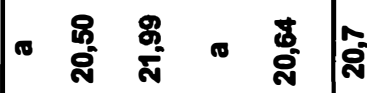

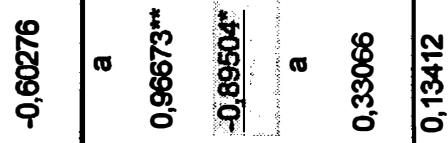

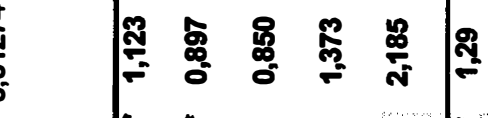

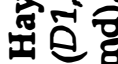

ะ

웜의

离

은 움

品

\&

政

品

啊

这客

๑

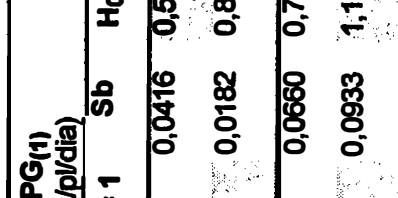

항ㅎㅁ

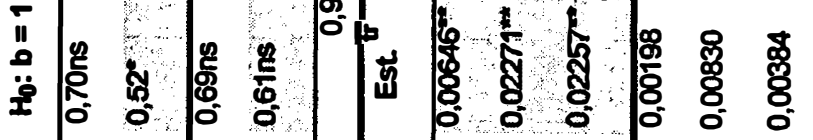

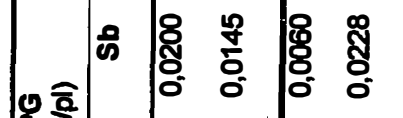

20 흥

竞

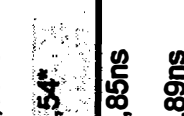

啳

然

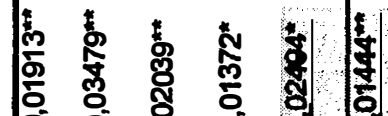

क्ष

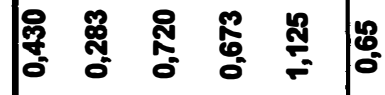

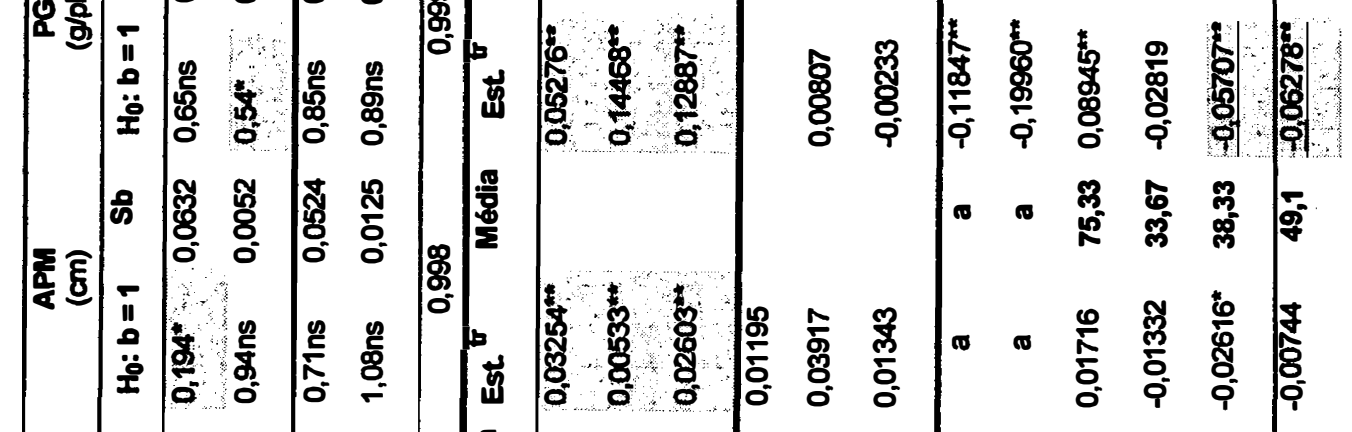

훈 $\overline{5}$

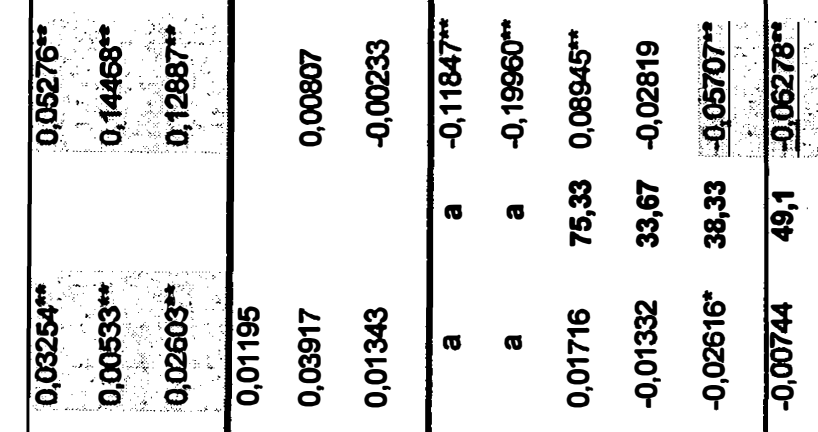

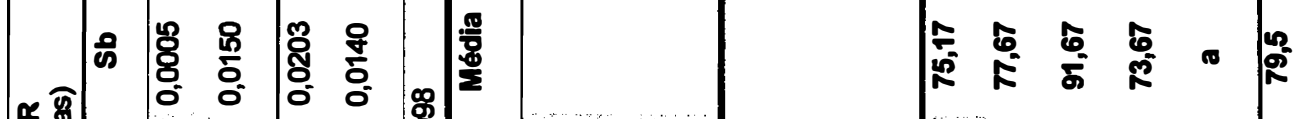

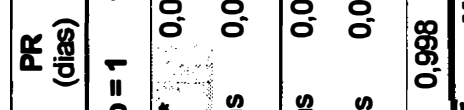

落

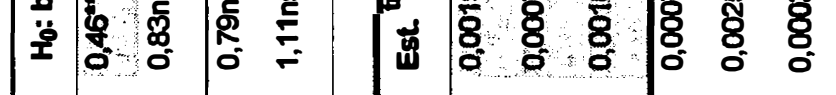

$=$ के

重副

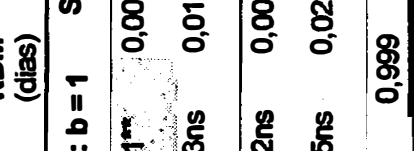

(1)

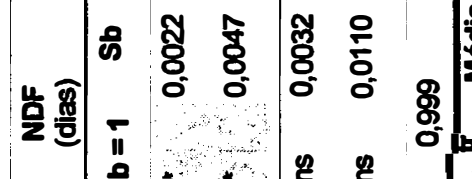

$\frac{1}{8}$ :

壁 8

:

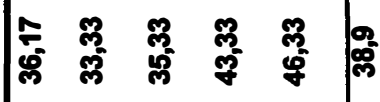

愛

范

860

: : : : 8

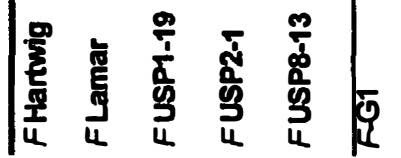


ช్ู่ี

จํํำ

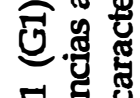

st

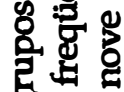

wo

8

날

을 즐

ํํำ

을 곤

ㄴ.

표용

홍ํำ

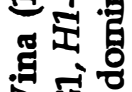

혼동

호ㅁㅗㅗ홍

ㅇํㄹ웜

을

등

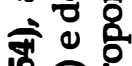

ฝึ่ คิ

E0 0

สี่ ธิ

蛋司

ช

융 矛

홍 웜

음 웜

ณ

붕 웅

\&

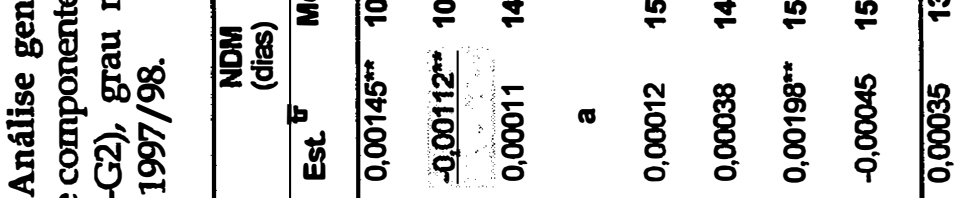

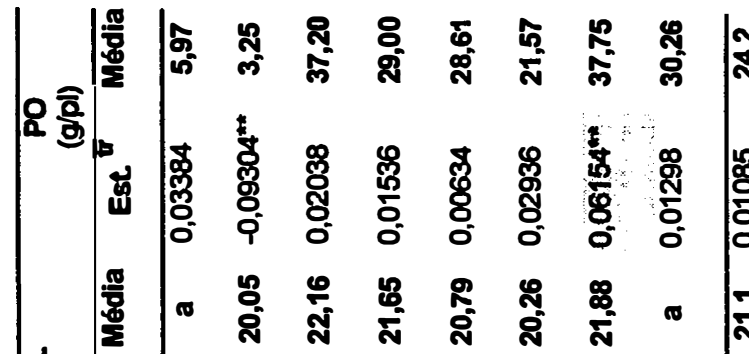

옹

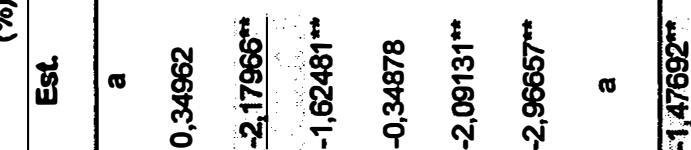

营

똔형

웜

部

总

ষ⿱廿⿻中一㇉丶⿻

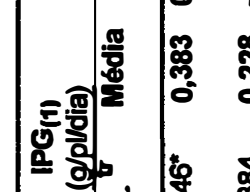

㟧

要

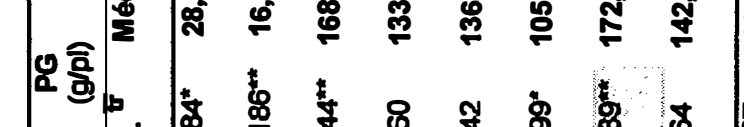

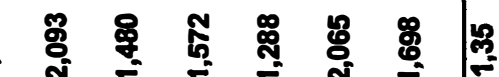

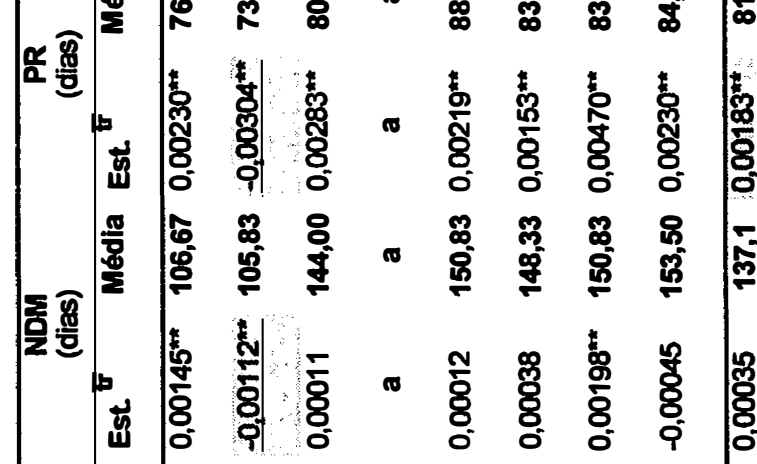

व

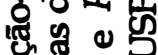

害的官

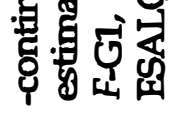

mi

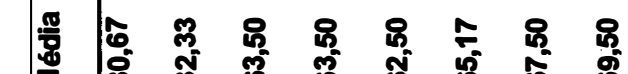

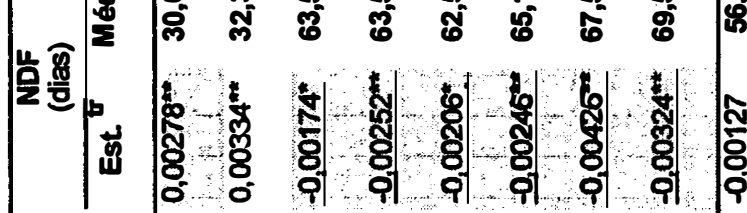

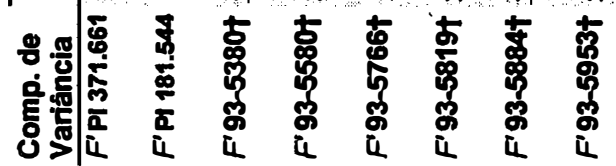

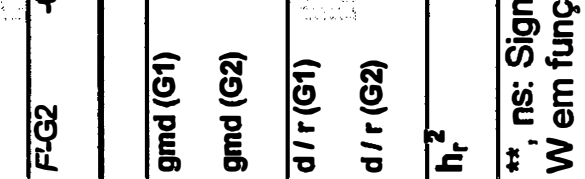

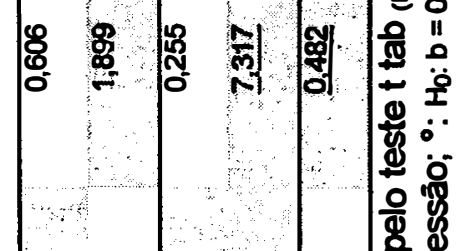

(\%)

O. 0 की

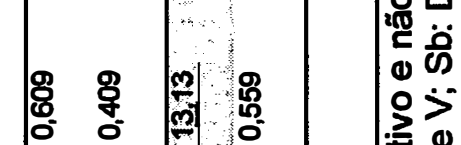

$\frac{\pi}{\sqrt{3}}$ 
FIGURAS 

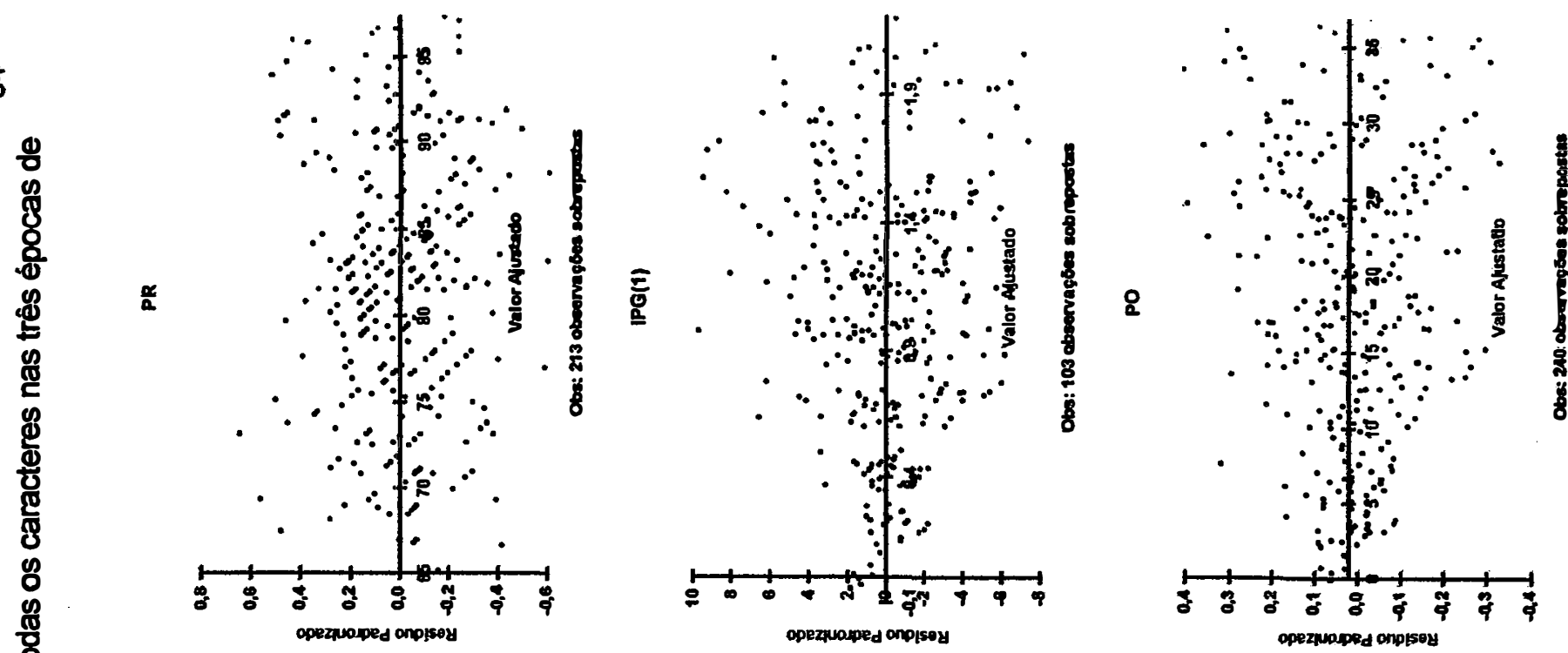

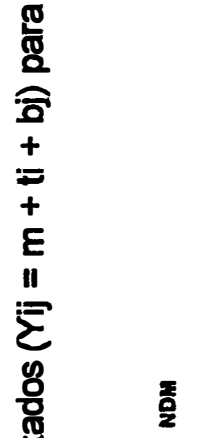
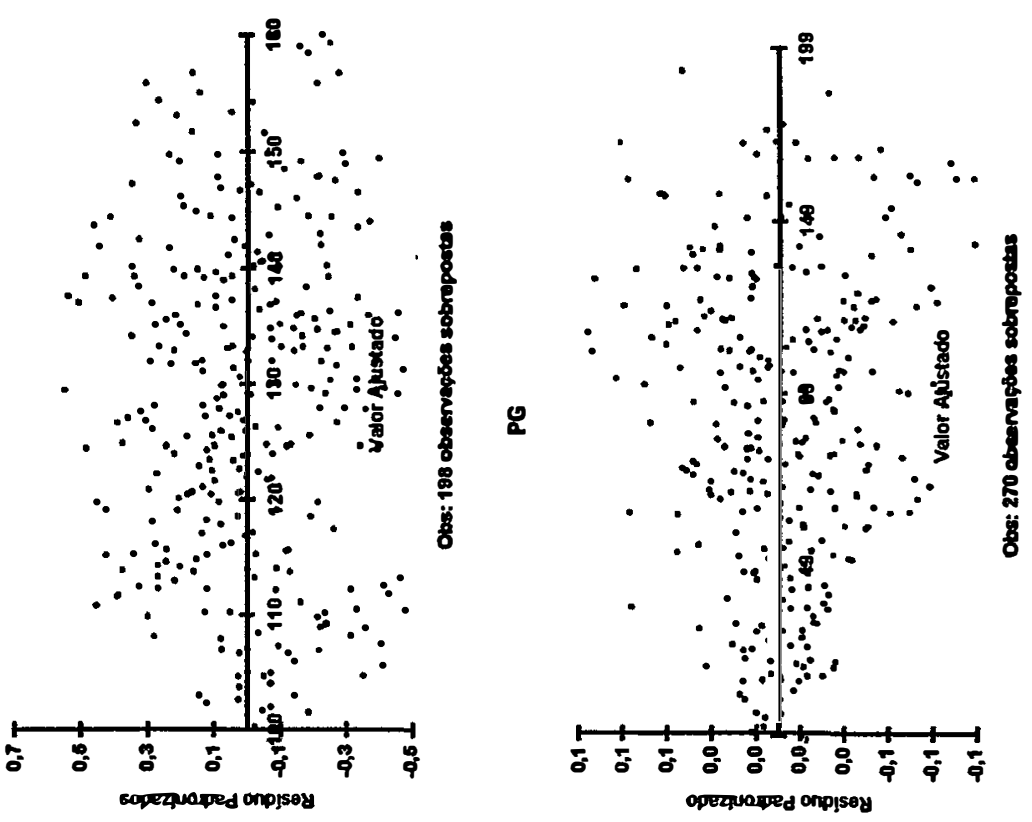

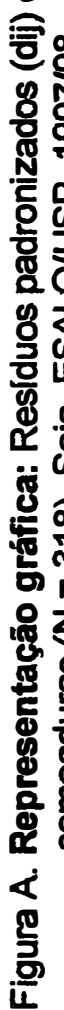
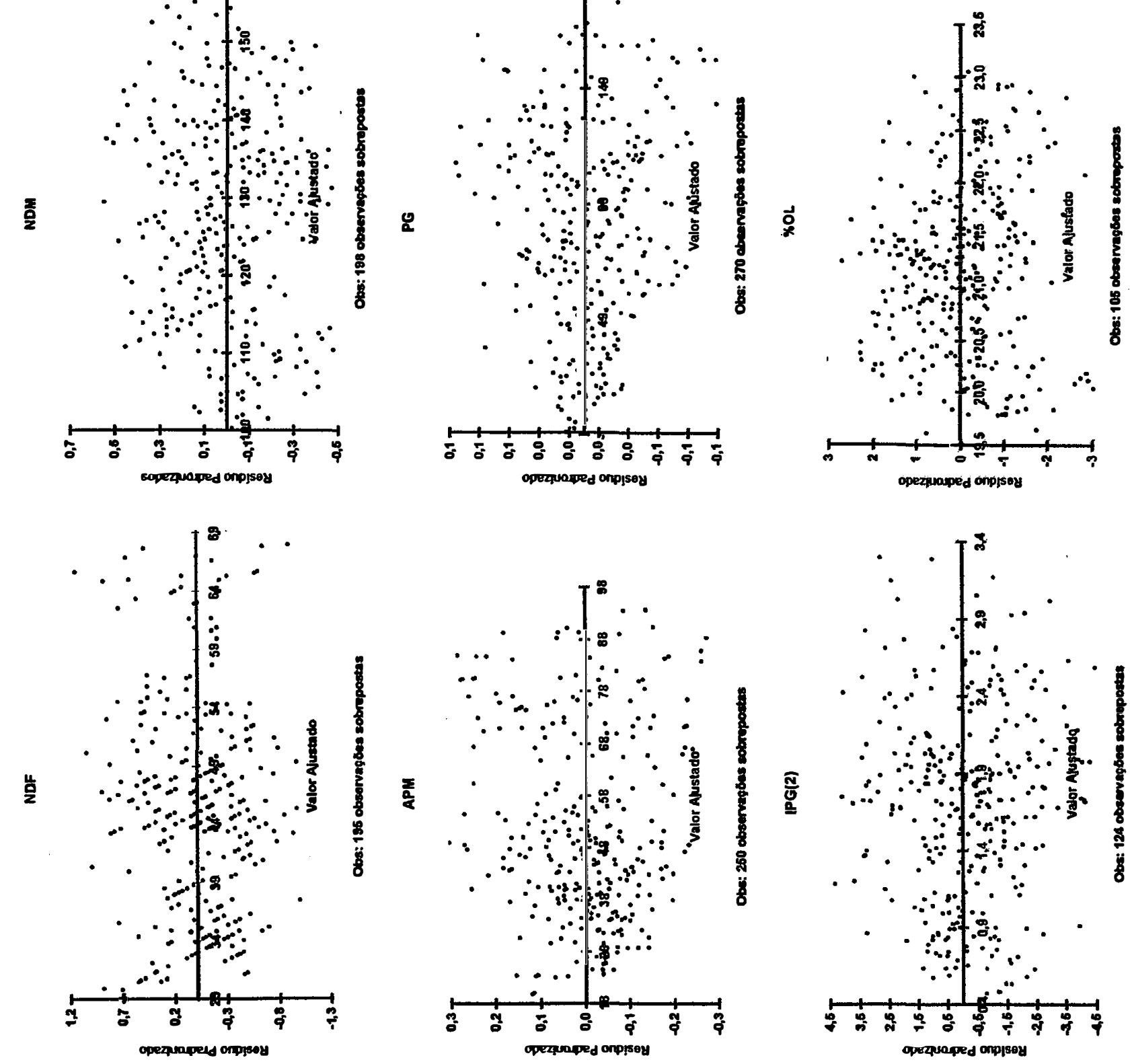
Figuras B e C: Analise gráfical do dialelo parcial 5 × 8 pelo método de Hayman (1954), adaptado por Viana (1994): Teste de suficiéncia $\left(H_{0}: b=1\right)$ do modelo Aditivo-Dominante e distribuição dos genes dominantes e recessivos entre os parentais, para nove caracteres. Soja, ESALQ/USP, 1997/98.

Figura b.1: NDF (G1)

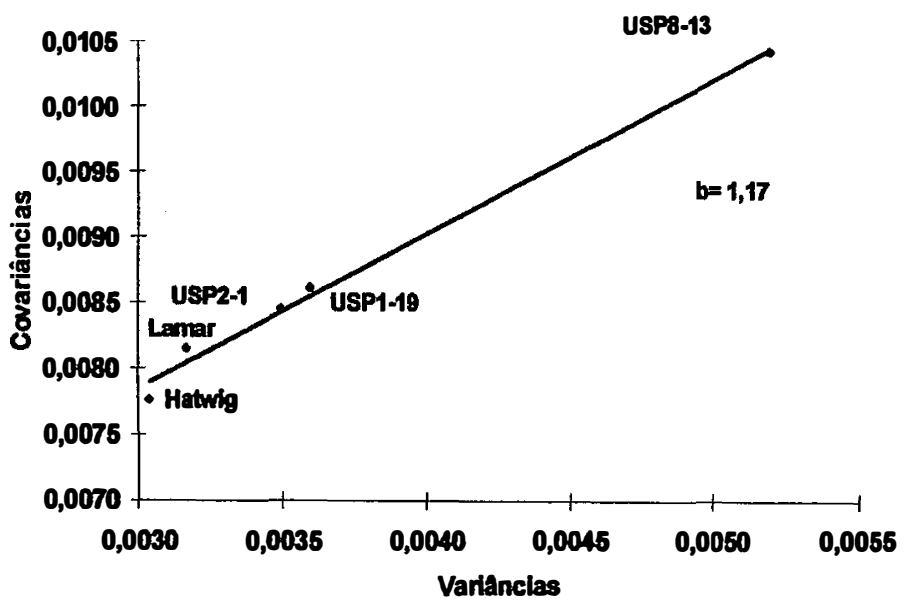

Figura b.2: NDM(G1)

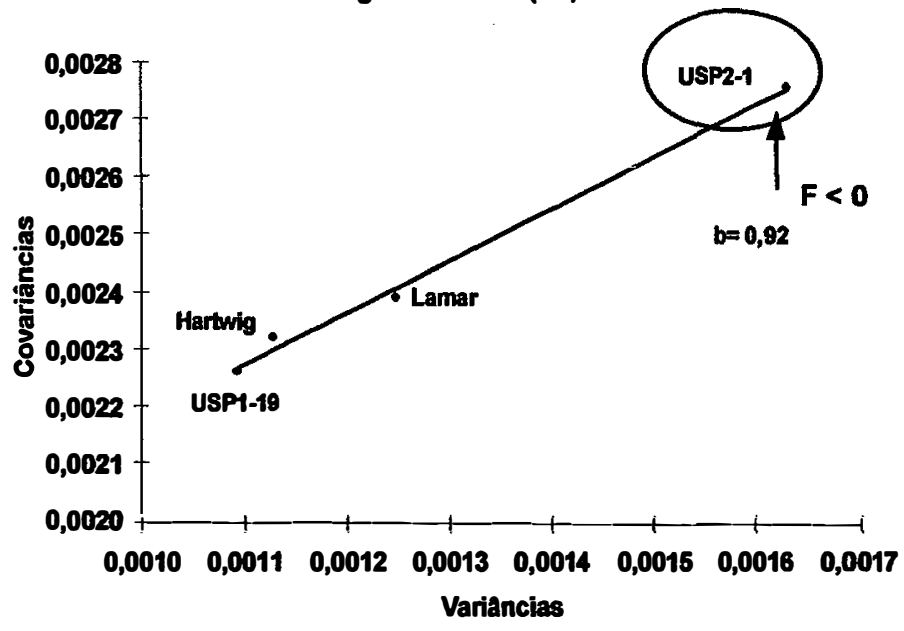

Figura b.3: PR (G1)

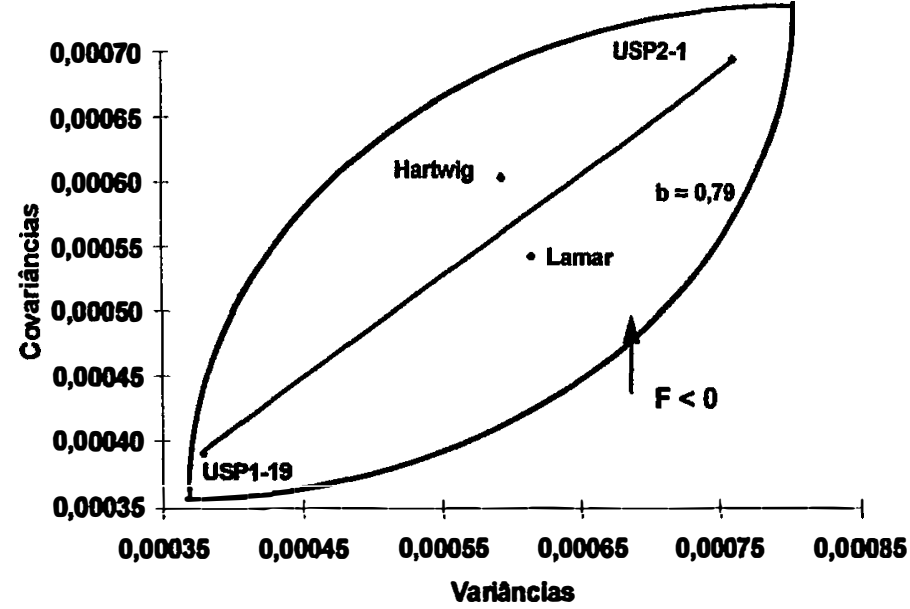

Figura c.1: NDF (G2)

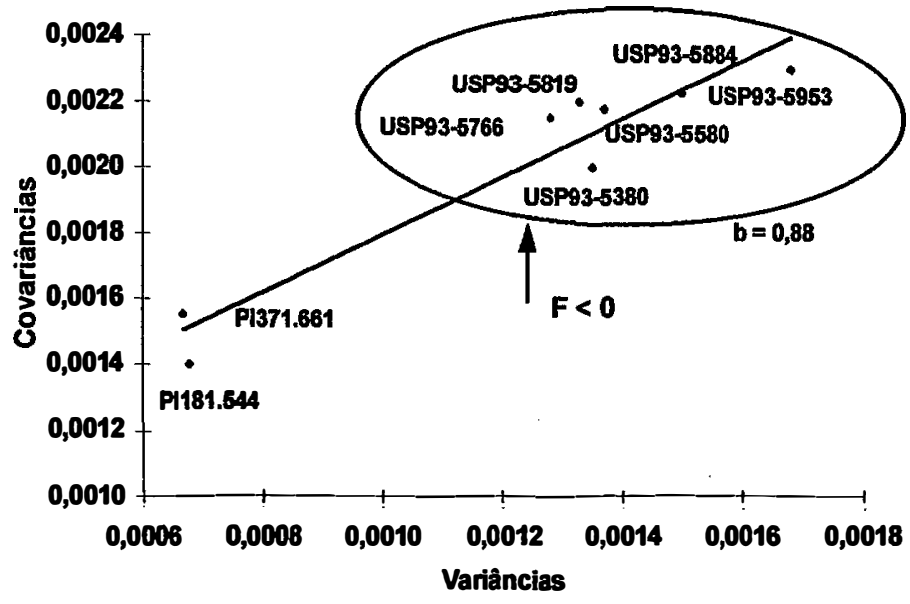

Figura c.2: NDM (G2)

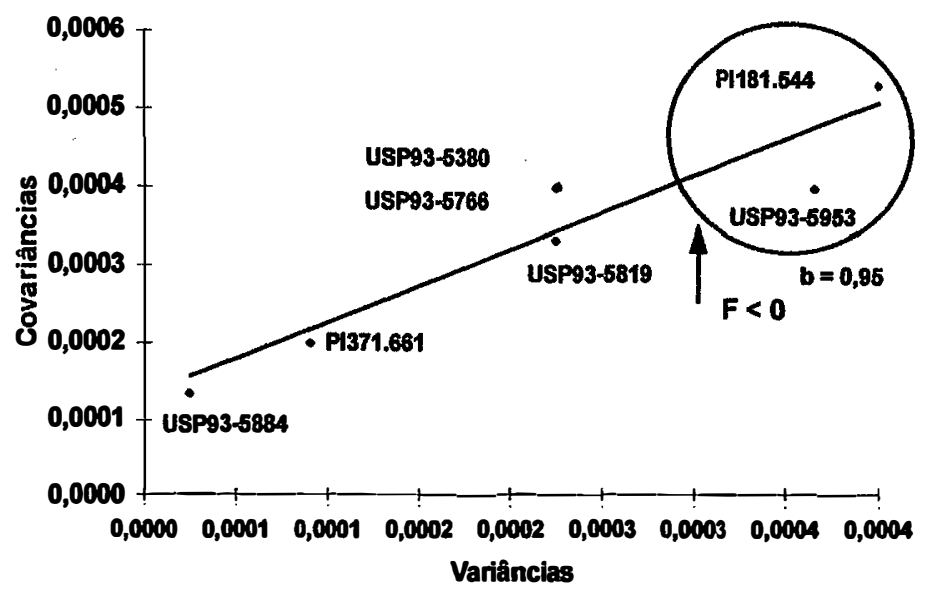

Flgura C.3: PR (G2)

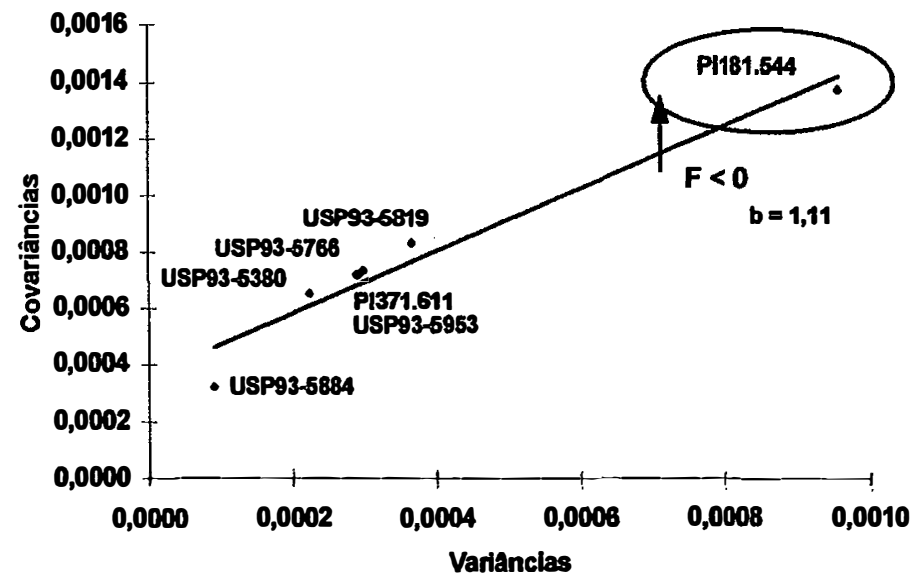

al. Baseada no princípio de que os parentais com maior frequência de alelos dominantes produzirăo progênies com minima variåncia entre si e mínima covariância parental-progênie; $F$ < 0 : Indica que as frequências dos alelos recessivos såo maiores que as frequências dos alelos dominantes. Comparar com a Tabela 13. 
Figuras B e C: Analise gráfica ${ }^{21}$ do dialelo parcial 5 × 8 pelo método de Hayman (1954), adaptado por Viana (1994): Teste de suficiência $\left(H_{0}: b=1\right)$ do modelo Aditivo-Dominante e distribuição dos genes dominantes e recessivos entre os parentais, para nove caracteres. Soja, ESALQ/USP, 1997/98.

Figura b.4: APM (G1)

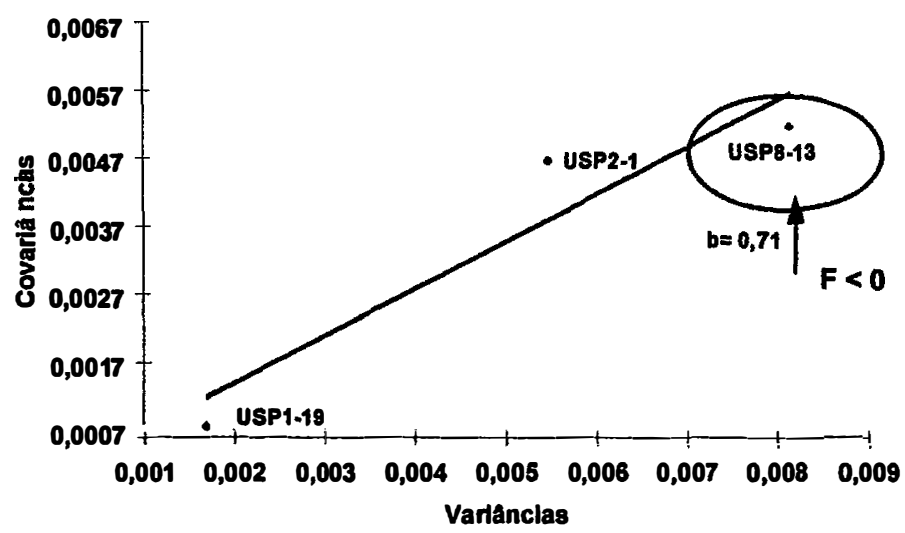

Figura b.5: PG(G1)

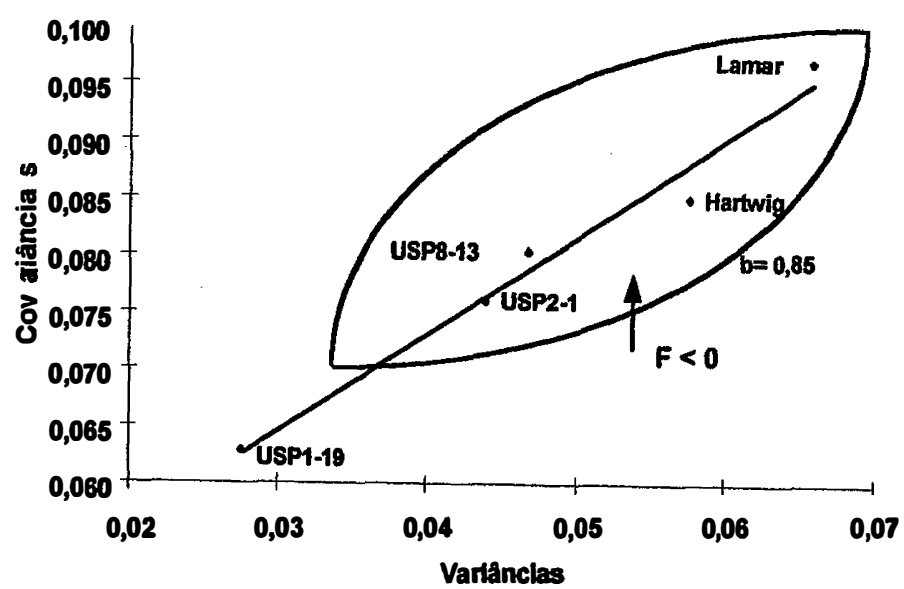

Figura b.6: IPG(1) (G1)

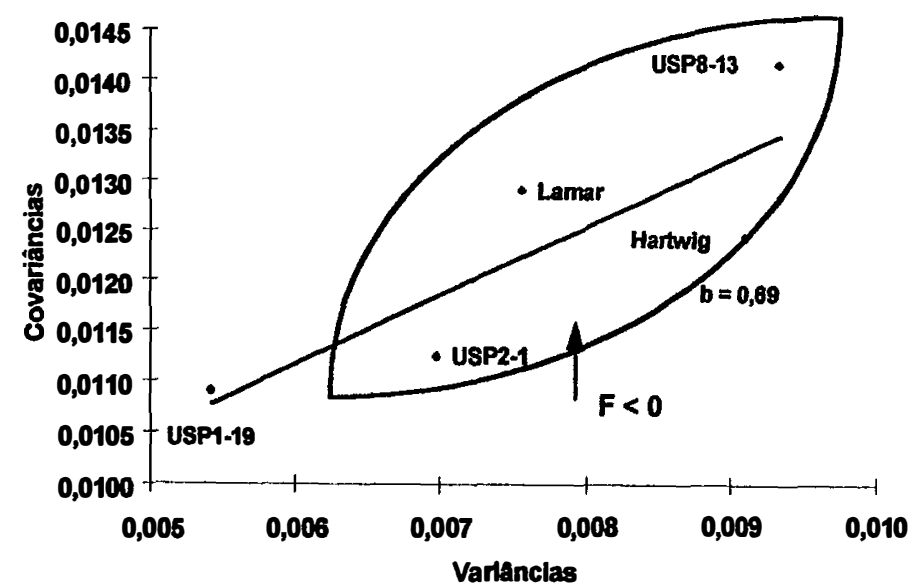

Figura c.4: APM (G2)

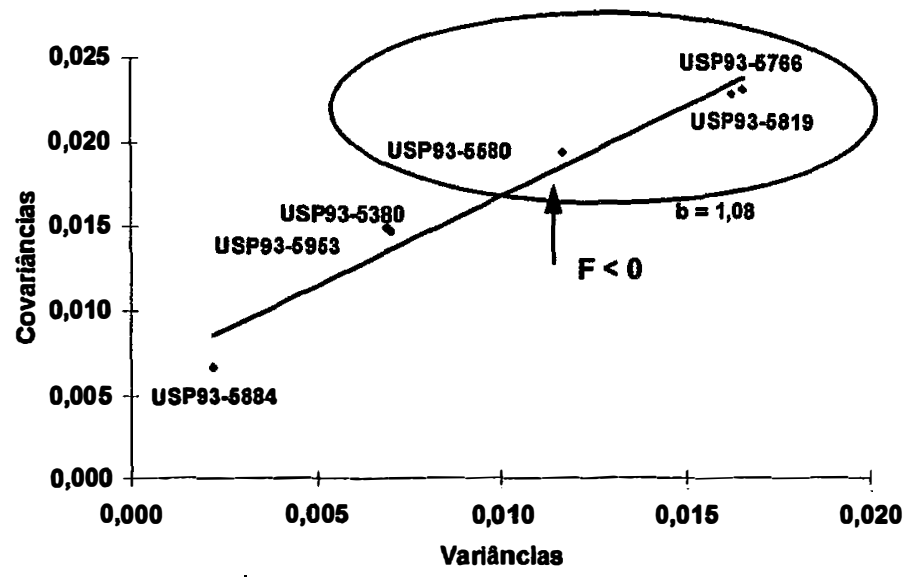

Figura c.5: PG (G2)

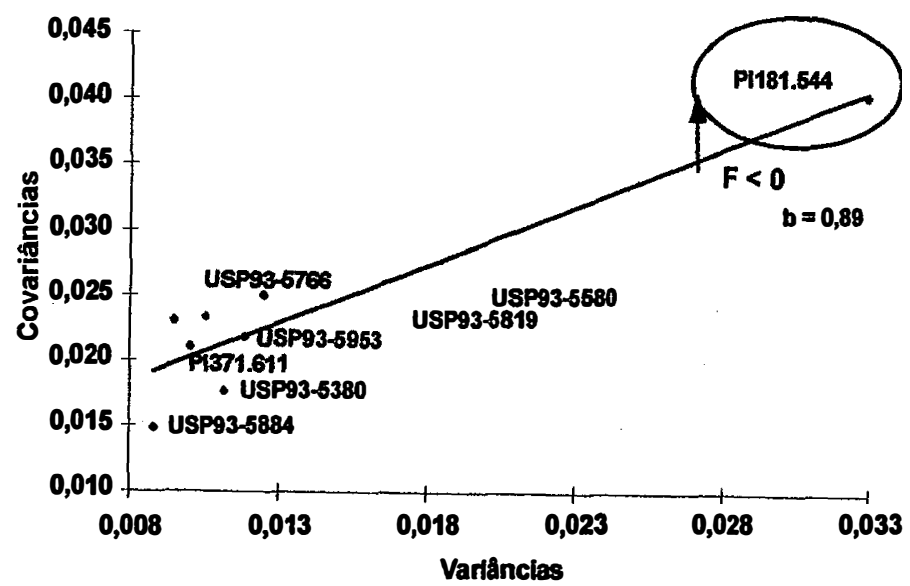

Figura c.6: $I^{P G}(1)$ (G2)

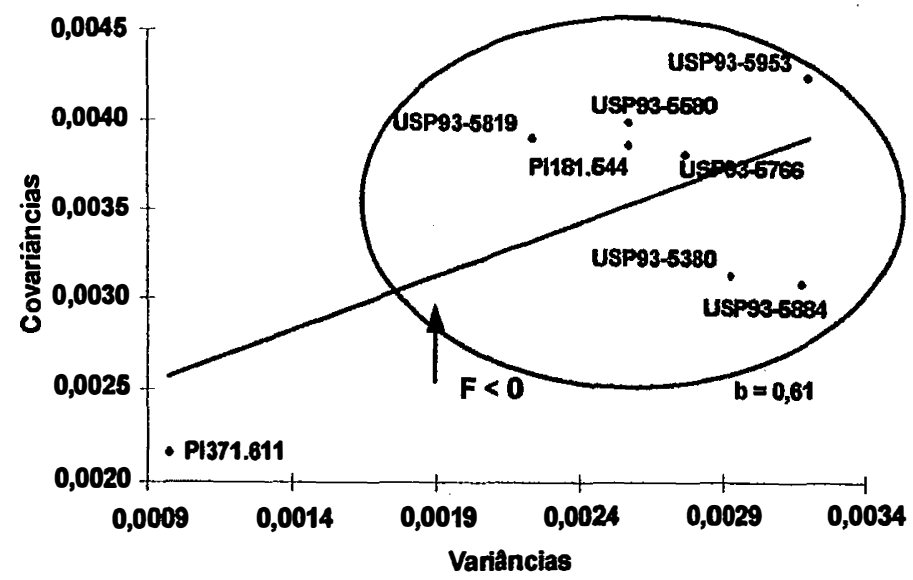

al :Baseada no principio de que os parentais com maior frequência de alelos dominantes produzirảo progénies com mínima variåncia entre si e mínima covariância parental-progénie; $F$ < 0 : Indica que as frequências dos alelos recessivos são maiores que as frequências dos alelos dominantes. Comparar com a Tabela 13. 
Figuras B e C: Analise gráfica ${ }^{2}$ do dialelo parcial 5 × 8 pelo método de Hayman (1954), adaptado por Viana (1994): Teste de suficiência $\left(H_{0}: b=1\right)$ do modelo Aditivo-Dominante e distribuição dos genes dominantes e recessivos entre os parentais, para nove caracteres. Soja, ESALQ/USP, 1997/98.

Figura b.7: $\operatorname{IPG}_{(2)}(\mathrm{G} 1)$

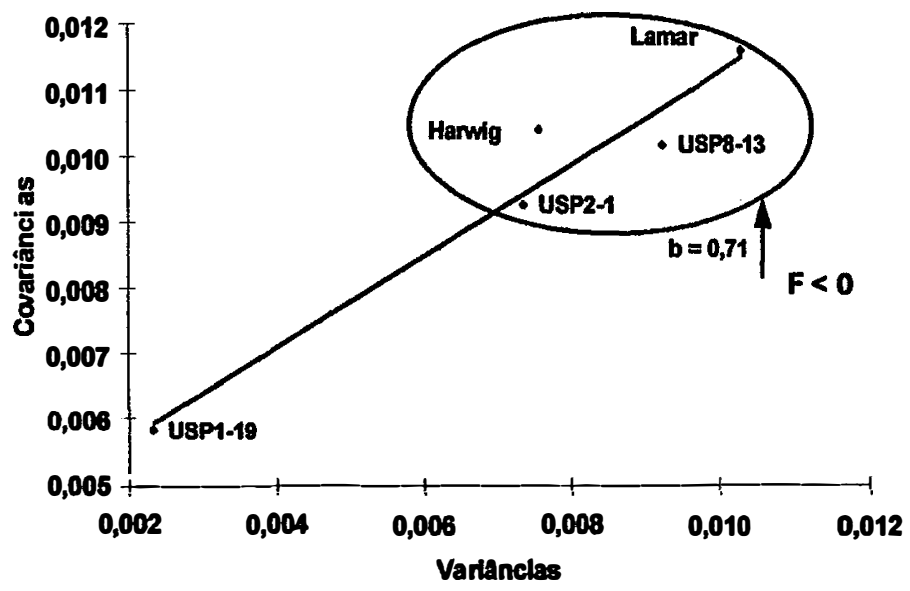

Figura b.8: \%OL (G1)

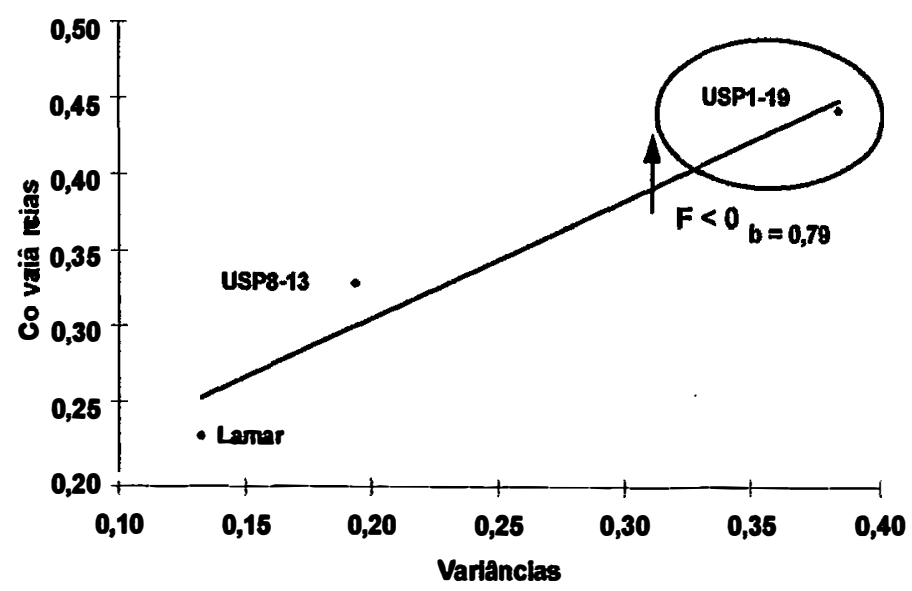

Figura b.9: PO(G1)

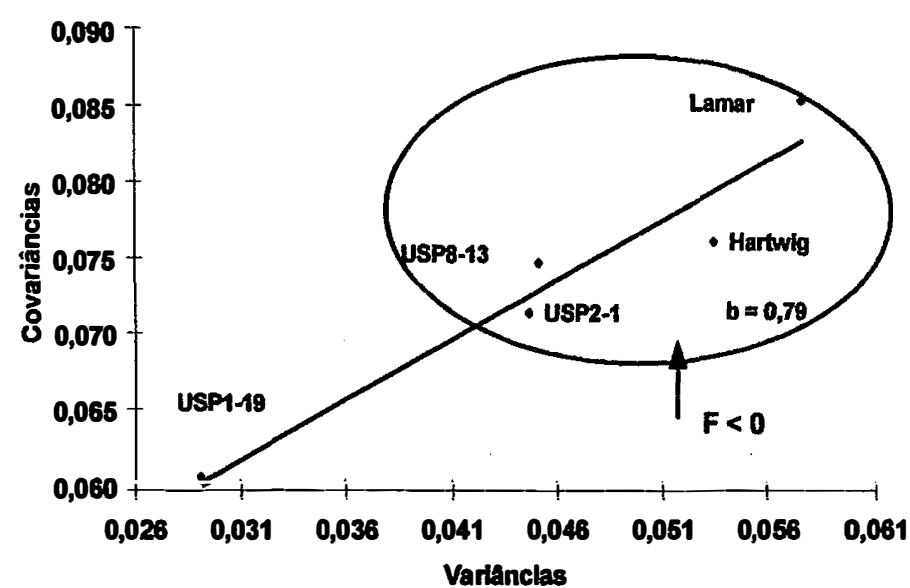

Flgura c.7: $\mathbb{P P G}_{(2)}(\mathbf{G} 2)$

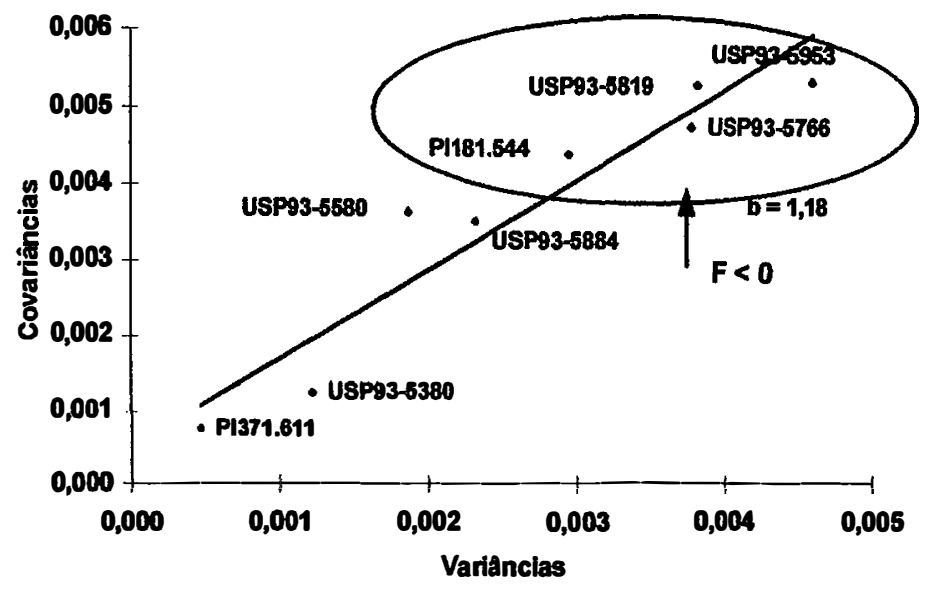

Flgura c.8: \%OL (G2)

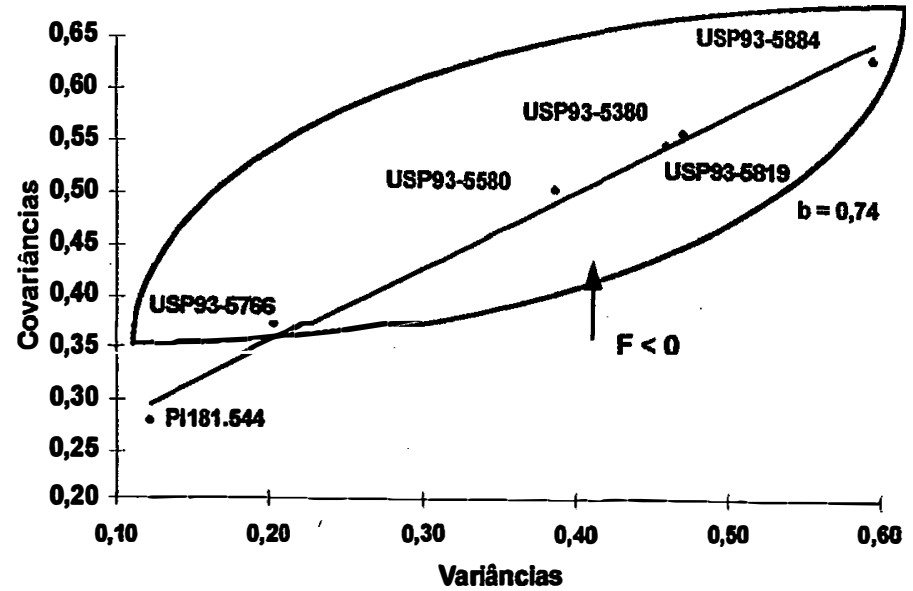

Figura c.9: PO (G2)

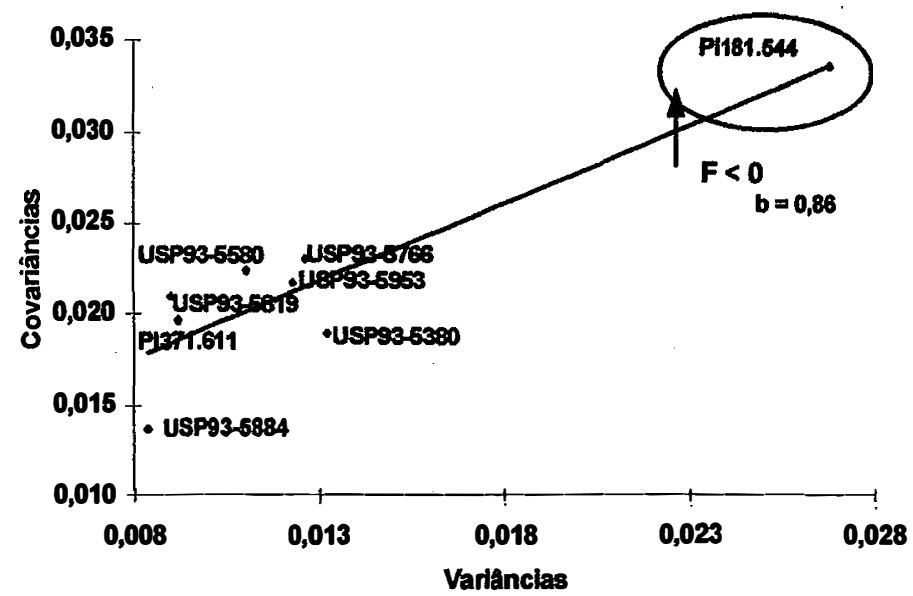

al :Baseada no princípio de que os parentais com maior frequência de alelos dominantes produzirăo progénies com minima variância entre si e mínima covariância parental-progênie; $F<0$ : Indica que as frequências dos alelos recessivos são maiores que as frequências dos alelos dominantes. Comparar com a Tabela 13. 
APÊ NDICES 
Apêndice A. Composição química e valor econômico da soja

O melhoramento genético da soja para PG permite manter e/ou aumentar a \%OL, devido às correlações genéticas entre ambos serem positivas, porém reduz o teor de proténa devido às correlaçð̄es genéticas serem negativas. Alguns modelos têm sido propostos para estimar o valor econômico da soja com base na \%OL, teor de proteína e PG. No melhoramento genético futuro da soja, estes modelos deverão ser considerados no auxilio da seleção de cultivares com maior valor econômico.

\section{A.1 Padrões internacionais de composição e preços}

- Porcentagem de proteína peso seco (\% Pps): $41-41,5 \%$

- Porcentagem de proteína com 13\% de umidade (\%P13\%): $36-36,5 \%$

- Porcentagem de óleo peso seco (\%Ops): $20,5-21 \%$

- Porcentagem de 6́leo com $13 \%$ de umidade (\%O13\%): $17-18 \%$

- Porcentagem de 6leo + proteína peso seco: $(\% \mathrm{POps}=\% \mathrm{Pps}+\% \mathrm{Ops})$ $.62 \%$

- Porcentagem de 6leo + proteína com $13 \%$ de umidade (\%PO13\%): $53-54 \%$

- Porcentagem de proteína no farelo com $13 \%$ de umidade (\%PF13\%): $. .44-48 \%$

- Preço da tonelada de grãos (PTG): $.230 \mathrm{US} \$ / \mathrm{t}$

- Preço da proteína (PP) em uma tonelada de grãos (TG): $65 \%$ do valor da tonelada de grãos: 149,5 US\$

- Preço do 6́leo (PO) em uma tonelada de grãos (TG): 35\% do valor da tonelada de grãos:

$.80,5$ US\$

- Quociente: preço da tonelada de farelo (PIF) / preço da tonelada de óleo (PTO) (corresponde a PTF = PTO $\cong 50 \%$ do valor da tonelada de grãos) $\geq 0,228$

- Relação: preço da tonelada de bleo (PTO) : preço da tonelada de farelo (PTF):$\cong 2: 1$

- Diferença entre produtividade de grãos de cultivares com 41\%Ps e produtividade de grãos de cultivares de alta proteína com $50 \% \mathrm{Pps}$ : $.20-24 \%$ Relação entre componentes: ..+ 1,5 \%Pps : - 1,0 \%Ops : - 0,5 \%Resíduo (carboidratos, cinzas)

\section{A.2 Suposições para o cálculo do valor econômico}

- Quociente: preço tonelada farelo (PTF) / preço tonelada óleo (PTO): $.0,405(189 / 466,4)$

- Relação: PTO : PIF:

- Produtividade média de grãos (PMG): $.2,2 \mathrm{t} / \mathrm{Ha}(100 \%)$ 
- Diferença entre produtividade de grãos de cultivares com $41 \%$ Pps e produtividade de grãos de cultivares de alta proteína com $50 \%$ Pps: $\cong 22 \%$

- Perdas por processamento industrial (PPI):

1) Perda relativa: óleo que fica no farelo:. $\cong 0.80 \% \mathrm{ps}$

- Fator de correção em fórmulas: $.0,9920$

2) Perda efetiva: $\cong 4,64 \%$ farelo

- Fator de correção em fórmulas: $.0,9536$

- Relação entre componentes e produtividade de grãos: + 0,5\%Pps : - 0,33\%Ops : + 0,17\%POps : - 1,29\%PG

\section{A.3 Fórmulas de cálculo}

$$
\begin{gathered}
\% \mathrm{P} 13 \%=\text { \%Pps *0,87; \%O13\%= \%Ops *0,87; \%PO13\%= \%POps *0,87 } \\
\text { \%PF13\% }=[-0,1343+(0,6712 * \% 013 \%)+(1,3203 * \% P 13 \%)]
\end{gathered}
$$

\section{A.3.1 Modelo 1}

US $\$$ / $t(1)=\frac{\text { PTO }}{\frac{1}{\left(\% 013 \%{ }^{*} 0,992\right)}}+\frac{\text { PTF }}{\frac{1}{(1-\% 013 \%)^{\star} 0,9536}} ; \quad$ US $\$ / \mathrm{Ha}(1)=$ US $\$ / \mathrm{t}(1)$ *PG.t $/ \mathrm{Ha}$

\section{A.3.2 Modelo 2}

$$
\text { US } \$ / \mathrm{t}(2)=(\mathrm{PTO} * \% 013 \%)+\frac{\mathrm{PTF}}{0,44} * \% \mathrm{P} 13 \% ; \quad \mathrm{US} \$ / \mathrm{Ha}(2)=\mathrm{US} \$ / \mathrm{t}(2) * \mathrm{PG} . \mathrm{t} / \mathrm{Ha}
$$

PG. $t /$ ha: Produtividade de grãos em toneladas/hectare.

US\$/t(1); US\$/t(2): Valor de uma tonelada de soja segundo os modelos 1 e 2.

US\$/ha(1); US\$/ha(2): Valor da soja obtido em um hectare segundo os modelos 1 e 2.

Adaptado de Updaw \& Nichols (1979) e Leffel (1990). 
Apêndice B1. Material genético: Parentais envolvidos nos cruzamentos dialélicos parciais $5 \times 8$, pertencentes à coleção de germoplasma do Setor de Genética Aplicada às Espécies Autógamas, Departamento de Genética, ESALQ/USP.

\begin{tabular}{|c|c|c|c|c|c|c|c|}
\hline Grupo & Código & Parental & Características & Genealogia & $\mathbf{C F}$ & $\mathbf{C P}$ & Descrição \\
\hline \multirow{5}{*}{ G1 } & 1 & Hartwig & RNCS & Forrest $(3) \times$ PI 437.654 & $\bar{B}$ & $\overline{\mathbf{M}}$ & Cultivares \\
\hline & 2 & Lamar & RCHS, RMID & Tracy-M X (Centerrial x D75-10169) & B & $\mathbf{M}$ & exóticos \\
\hline & 3 & USP-01-19 & \multirow{3}{*}{ RCHS, RNCS } & IAC-Foscarin $31 \times$ Forrest $^{1}$ & B & $\mathbf{M}$ & Linhagens \\
\hline & 4 & USP-02-01 & & Forrest ${ }^{1} \times$ Primavera & B & $\mathbf{M}$ & experimentais \\
\hline & 5 & USP-08-13 & & Foster $^{1}$ x FT 79-3408 & B & C & \\
\hline \multirow{7}{*}{ G2 } & $\begin{array}{l}6 \\
7\end{array}$ & $\begin{array}{l}\text { PI } 371.611 \\
\text { PI 181.544 }\end{array}$ & $\begin{array}{l}\text { Óleo }(27,6 \%)^{*} \\
\text { Óleo }(25,0 \%)^{*}\end{array}$ & & $\begin{array}{l}\mathbf{R} \\
\mathbf{R}\end{array}$ & $\begin{array}{l}\mathbf{M} \\
\mathbf{M}\end{array}$ & $\begin{array}{l}\text { Novas } \\
\text { introduçőes }\end{array}$ \\
\hline & 8 & USP93-5288 & \multirow{6}{*}{ Alto Óleo } & Paranagoiana $\times$ Jackson 4028-s & B & $\mathbf{C}$ & \multirow{6}{*}{$\begin{array}{l}\text { Linhagens } \\
\text { experimentais }\end{array}$} \\
\hline & 9 & USP93-5580 & & Planalto-s x G081-11094 & $\mathbf{R}$ & $\mathbf{M}$ & \\
\hline & 10 & USP93-5766 & & EMGOPA 301 x IAC-9 & $\mathbf{R}$ & C & \\
\hline & 11 & USP93-5819 & & GO 79-1030 x Cristalina-s & $\mathbf{R}$ & $\mathbf{M}$ & \\
\hline & 12 & USP93-5884 & & IAC-6 $\times$ UFV-4 & $\mathbf{R}$ & $\mathbf{M}$ & \\
\hline & 13 & USP93-5953 & & BR 80-76309 x UFV-1 & $\mathbf{R}$ & $\mathbf{M}$ & \\
\hline
\end{tabular}

CHS: Resistencia ao Cancro da Haste da Soja; RNCS: Nematoide de Cisto da Soja; RMID: Resistencia Múltipla a Insetos Defoliadores; ${ }^{1}$ : Resistente ao NCS; (3): 93,75\% do genoma de Forrest; *: Fonte: Germplasm Resource Information Network (GRIN): SoyBase; $R$ e B: Flor roxa e branca; $M$ e C: Pubescencia marrom e cinza.

i) As linhagens experimentais adaptadas (USP) foram desenvolvidas pelo Setor de Genética Aplicada às Espécies Autogamas, Departamento de Genética, ESALQ/USP. As nove linhagens experimentais são: USP-01-19, USP-02-01 e USP-08-13, com resistencia tripla [Nematoide do Cisto da Soja (Heterodera glycine Ichinohe), Cancro da Haste da Soja Diaporthe phaseolorum f. sp. meridionalis (Morgan \& Jones) e Mancha olho-de-rã Cercospora sojina] (Vello et al., 1994; Hiromoto, 1996); e as linhagens: USP93-5280, USP93-5580, USP93-5766, USP93-5819, USP93-5884 e USP93-5953 com alta produtividade de 6leo (Laínez-Mejía, 1996). As seis linhagens experimentais com alta produtividade de oleo foram obtidas por cruzamentos biparentais em cadeia circulante, cinco a partir de cadeia mista (50\% de genes adaptados e $50 \%$ de genes ex6́ticos) e uma a partir de cadeia adaptada (100\% de genes adaptados).

ii) O cultivar Hartwig representa a multiplicação de uma linhagem F4 do cruzamento Forrest ${ }^{3}$ x PI 437.654, desenvolvido pela Estação Expenimental Agricola de Missouri, nos Estados Unidos e liberado por Anand (1992) como o primeiro cultivar de soja resistente a todas as raças conhecidas de Nematóide de Cisto da Soja (Heterodera glycine Ichinohe). A resistência de Hartwig foi derivada da PI 437.654 por retrocruzamentos das plantas $F_{2}$ resistentes com Forrest. As plantas $\mathrm{F}_{2}$ de cada ciclo foram avaliadas em casa de vegetação com uma população composta por mistura das raças 1, 2, 3, 4, 5, 6, 9 e 14. Hartwig também é resistente ao Nematóide de Galhas da Soja [Meloidogyne incognita (Kofoid \& Write) Chitwood], ao 
Nematoide Reniforme [Rotylenchulus reniformis (Linford \& Oliveira)] e apresenta altos niveis de resistência à Síndrome da Morte Súbita ou Podridão Vermelha da raiz [Fusarium solani (Mart.) Sacc.]. O cultivar é suscetfvel ao Meloidogyne arenaria (Neal) Chiwood e ao Cancro da Haste da Soja [Diaporthe phaseolorum (Cooke \& Ellis) Sacc. var. caulivora (Athow \& Caldwell)]. A planta é de crescimento determinado, com flores brancas e pubescência marrom, e pertence ao grupo de maturidade V. O cultivar leva o nome do Dr. E. E. Hartwig do Departamento de Agricultura dos Estados Unidos (USDA-ARS), devido às suas contribuiç̧̋es para o desenvolvimento de cultivares de soja nos Estados Unidos.

iii) O cultivar Lamar representa a multiplicação de uma linhagem $F_{5}$ do cruzamento Tracy-M × $\mathrm{F}_{3}$ Sel., desenvolvida pelo Departamento de Agricultura dos Estados Unidos (USDA-ARS) e liberada por Hartwig et al. (1990), com ampla resistencia a insetos defoliadores. O genótipo F3 Sel. (Centennial x D75-10169) mostrou baixo nivel de defoliação, similar a D7510169, após infecção com alta densidade populacional de lagartas da soja Pseudoplusia includens (Walker) e foi empregado como parental macho no cruzamento com Tracy-M. A resistencia a insetos defoliadores foi derivada do cultivar japonês Soden-daizu (PI 229.358). Lamar também é resistente à Pústula Bacteriana [Xanthomonas phaseoli (E. F. Sm.) Dows. var. sojensis (Hedges) (Starr \& Burkn)], à Podridão de "Phytophthora" [Phytophthora magasperma Drechs. f. sp. glycinea (Kuan \& Erwin)], ao Cancro da Haste da Soja [Diaporthe phaseolorum (Cooke \& Ellis) Sacc. var. caulivora (Athow \& Caldwell)], ao Nematóide de Galhas da Soja [Meloidogyme incognita (Kofoid \& White) Chitwood], e contém uma porção do complexo genico para resistência à raça 3 de Nematóide de Cisto da Soja (Heterodera glycine Ichinohe). A planta é de crescimento determinado, com flores brancas e pubescência marrom, e pertence ao grupo de maturidade VI.

iv) As PI 181.544 e PI 371.611 são introduções de plantas do banco de germoplasma norte-americano (Germplasm Resource Information Network (GRIN): SoyBase); as sementes foram obtidas da EMBRAPA - Centro Nacional de Pesquisa de Soja - CNPSo / Londrina, PR.

Apêndice B2. Condições ambientais: Precipitação pluviométrica e temperatura média ocorridas no período experimental (Setembro/97-Maio/98). Departamento de Física e Meteorologia, ESALQ/USP.

\begin{tabular}{lccccccccc}
\hline & Set/97 & Out/97 & Nov/97 & Dec/97 & Jan/98 & Fev/98 & Mar/98 & Abr/98 & Mai/98 \\
\hline Precipitaçāo & 95 & 63 & 269 & 187 & 121 & 362 & 128 & 67 & 98 \\
$(\mathbf{m m})$ & $(63)$ & $(110)$ & $(131)$ & $(199)$ & $(222)$ & $(186)$ & $(142)$ & $(65)$ & $(53)$ \\
$T^{0}$ Méd. Max. & 29,4 & 29,4 & 30,3 & 31,1 & 31,7 & 30,0 & 31,0 & 28,4 & 24,9 \\
Máxima(C) & $(28,1)$ & $(28,9)$ & $(29,6)$ & $(29,6)$ & $(29,9)$ & $(30,2)$ & $(29,9)$ & $(28,3)$ & $(26,1)$ \\
\hline
\end{tabular}


Apêndice C. Considerações práticas sobre a determinação do teor de 6́leo por Espectrômetro de Ressonância Magnética Nuclear (NMR)

O conhecimento do teor de óleo em sementes e grãos é indispensável para a seleção genética de cultivares de espécies oleaginosas com altos teores de oleo, para conhecer o potencial de produção dos grãos na agroindústria de refinamento do 6leo, para avaliar o valor energético dos alimentos, entre outros usos (Colnago, 1996).

Procedimentos de preparação das amostras padrões (AP) para determinar a curva de calibração (CC)

- Com base em informações prévias, escolher um conjunto de 30-40 genótipos com ampla variabilidade no teor de 6leo;

- A partir de uma amostra de grãos destes genótipos, determinar o teor de 6leo por extração com soxhlet, o método oficial da International Union for Pure and Applied Chemistry (IUPAC);

- Escolher o maior número possível destes genótipos (no mínimo 8-10), de maneira a representar a máxima amplitude de variação do conteúdo de 6leo (entre 15\%-25\%). Assim, cada genótipo deverá representar um ponto na $\mathrm{CC}$ a cada $0,5 \%$;

- Re-amostrar os genótipos escolhidos com um volume de grãos que pode variar da metade até o volume total da bobina receptora, o que representa em torno de 2,0-3,0g que serão empregados como AP para a calibração do NMR;

- As sementes das AP deverão ser mantidas em condiç̃es apropriadas de temperatura e umidade. É fundamental que as umidades das amostras experimentais (AE) e das AP sejam as mesmas e que se mantenham constantes durante o período das análises.

\section{Procedimentos de preparação das amostras experimentais (AE) a analisar}

- Amostragem das sementes de acordo com o volume da bobina receptora (o volume de sementes pode variar da metade até o volume total da bobina receptora), o qual representa em torno de 2,0-3,0g, e tomando o cuidado de não amostrar sementes danificadas (rachadas, enrugadas, verdes, etc);

- Estabilizar a umidade das AE e das AP em câmara seca. Durante a estabilização devese monitorar a cada 3-4 dias a redução do conteúdo interno de umidade das sementes, atraves do controle do peso das amostras testes (AT) (10 amostras). Estabilizado o peso (após aproximadamente 10 dias), as $\mathrm{APe}$ as $\mathrm{AE}$ estarão em condiç̃es de serem analisadas. 


\section{Procedimentos de análise}

Ajustado o módulo de controle de parametros do aparelho, inicia-se o módulo análise através do modo análise/calibração.

- A opção "calibração" ativa o processo de calibração do aparelho, no qual, através das AP, é construída uma curva de calibração que será usada na determinação da quantidade de óleo das AE (dentro do processo calibração, o próprio programa indica os procedimentos passo-a-passo);

- Para cada AP, o programa exige o peso de óleo em mg, o qual é calculado levando-se em consideração o peso da amostra em g e o teor de óleo em \%. E muito importante fixar as sementes dentro do tubo de análise de cada AP, a fim de manter o mesmo padrão de posicionamento das mesmas nos posteriores empregos para determinar novas $\mathrm{CC}$;

- Feita a leitura da última AP será traçada a curva de calibração sobre os pontos do gráfico. Dependendo do ajuste da CC, pode-se re-amostrar algumas ou todas as amostras padrōes;

- No momento em que o ajuste da curva for igual ou maior que $R^{2}=0,96\left(R^{2}=0,960\right.$ a 0,999), proceder a gravar a curva e a ativar a opção "análise";

- Para este procedimento o programa exige que se crie um arquivo texto para armazenar os dados, e também identificar as $\mathrm{AE}$ e digitar o peso em $\mathrm{g}$ das mesmas. $\mathrm{O}$ arquivo de amazenamento dos dados pode ser utilizado com diferentes $\mathrm{CC}$, já que os dados são gravados em continuação ao último dado da CC anterior;

- Durante as análises, recomendam-se repetir duas AT de baixo e alto teor de óleo e levar o registro dos dados a cada 15-20 AE, a fim de monitorar a manutenção da CC. Se as variações no teor de óleo nas sucessivas leituras das AT for maior do que a precisão exigida nas análises, refazer a CC;

- Recomenda-se refazer a CC após um periodo de trabalho de 0:45-1:15 horas;

Para outras informaçōes sobre o funcionamento e uso do NMR, consultar Montaño-Velasco (1994). 
Apêndice D1. Interação tratamentos $x$ pares de épocas de semeaduras (T x pares E): Desdobramento em partes simples (\%PS) e complexa (\%PC).

$$
\begin{aligned}
& \% P S=\frac{100 S}{\text { QMGXEss' }} \text { em que } S=\text { QMGXEss'-C } \\
& \text { sendo } \quad C=\sqrt{(1-r)^{3}} \text { QMGs * QMGs' } \% P C=\frac{100 C}{\text { QMGXEss' }}
\end{aligned}
$$

onde:

QMGxEss': quadrado médio da interação genótipos $\times$ pares de épocas de semeaduras;

QMGs e QMGs': quadrados médios de genótipos nas épocas de semeaduras s e s'.

Apêndice D2. Estratificação de épocas de semeaduras (E).

$$
\text { SQGXEss' }=\frac{1}{2}\left[d_{s s^{\prime}}^{2}\left(Y . s-Y . s^{\prime}\right)^{2}\right] \quad \text { em que } \quad d_{s s^{\prime}}^{2}=\sum_{i}\left(Y i s-Y i s^{\prime}\right)^{2}
$$

Apêndice D3. Análise de correlação: Decomposição do coeficente de correlação genética (rg) em ef eitos genéticos diretos (EGD) e indiretos (EGI).

$$
r g y x 1=p \times 1+p \times 2 * r y x 2+\ldots .+p \times n * r y x n+p e ; \quad p e=\sqrt{1-R^{2}}
$$

sendo:

rgyx1: correlação genética entre o caráter principal y e o caráter explicativo x1;

px1: efeito direto do caráter explicativo x1 sobre o caráter principal y;

px2*ryx2: efeito indireto do caráter explicativo $x 1$ através do caráter explicativo $\times 2$, sobre $\mathrm{o}$ caráter principal y;

pe: efeito da variável residual;

$\mathbf{R}^{2}$ : coeficiente de determinação.

Apêndice D4. Desdobramento da soma de quadrados de cruzamentos $(\mathrm{Cr})$ em somas de quadrados de capacidade geral e específica de combinação (CGC e CEC).

Os estimadores dos efeitos associados ao modelo são:

$$
\hat{u}=\frac{Y . .}{p q} ; \quad \hat{g} i=\frac{Y i .}{q}-\frac{Y . .}{p q}
$$




$$
\hat{g} j=\frac{Y . j}{p}-\frac{Y . .}{p q} ; \quad \hat{g} i j=Y i j-(\hat{u}-\hat{g} i-\hat{g} j)
$$

As estimativas dos quadrados associados aos efeitos da CGC e CEC são:

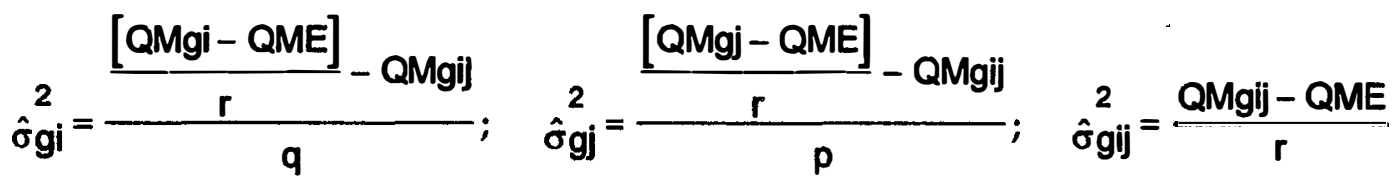

Os desvios padrões associados aos estimadores são:

$$
\begin{gathered}
s(\hat{u})=\frac{1}{p q} \times \frac{\hat{\sigma}_{e}}{r} ; \quad s(\hat{g} i)=\frac{p-1}{p q} \times \frac{\hat{\sigma}_{e}}{r} \\
s(\hat{g} j)=\frac{q-1}{p q} \times \frac{\hat{\sigma}_{e}}{r} ; \quad s(\hat{g} i j)=\frac{(p-1)(q-1)}{p q} \times \frac{\hat{\sigma} e}{r}
\end{gathered}
$$

Apêndice D5. Desdobramento da soma de quadrados de tratamentos (T) em somas de quadrados dos grupos $\mathbf{G 1}$ e G2, e o contraste $\mathbf{G}$ (G1 vs G2).

Os estimadores dos efeitos associados ao modelo são:

$$
\hat{u}=\frac{q Y(1)+p Y(2)}{2 p q} ; \quad \hat{v i}=Y i o-\frac{Y(1)}{p} ; \quad \hat{v} j=Y o j-\frac{Y(2)}{q}
$$

Os desvios padrões associados aos estimadores são:

$$
s(\hat{u})=\frac{p+q}{4 p q} \times \frac{\hat{\sigma}_{e}}{r} ; \quad s(\hat{v i})=\frac{p-1}{p} \times \frac{\hat{\sigma}_{e}}{r} ; \quad s(\hat{v} j)=\frac{q-1}{q} \times \frac{\hat{\sigma}_{e}}{r}
$$

Apêndice D6. Análise genética.

a) Teste de suficiência do modelo Aditivo-Dominante:

Coeficiente de regressão: $\hat{W} i=\hat{a}+\hat{b} \hat{V} i$ para Ho: $b=1$, associada a $n-2$ graus de liberdade.

$$
t=\frac{\hat{b}-1}{\sqrt{\hat{v}(\hat{b})}} ; \text { onde } \quad \hat{v}(\hat{b})=\frac{s^{2}}{\sum_{i}\left(\hat{V}_{i}-\hat{V}_{i}\right)^{2}}
$$


b) Os componentes genéticos associados às variâncias e covariâncias são:

b.1) Variância das médias genotípicas das gerações $F_{2}$ do parental $\mathbf{r}$ (variância no arranjo r).

$$
V r s=\frac{1}{4} D(2)-\frac{1}{8} F r+\frac{1}{16} H 1(2)+E ; \quad \text { sendo } r \text { fixo }
$$

b.2) Variância das médias genotípicas das gerações $F_{2}$ do parental s (variância no arranjo s).

$$
V r s=\frac{1}{4} D(1)-\frac{1}{8} F s+\frac{1}{16} H 1(1)+E ; \text { sendo s fixo }
$$

b.3) Variância das médias genotípicas das gerações $F_{2}$.

$$
V r s=V(F 2)=\frac{1}{4} D(1)+\frac{1}{4} D(2)-\frac{1}{8} F(1)-\frac{1}{8} F(2)+\frac{1}{16} H 1(1)+\frac{1}{16} H 1(2)-\frac{1}{16} H 2+E
$$

b.4) Média das variâncias genotípicas totais nas gerações $F_{2}$ do parental $r$.

$$
\bar{V} r s=\frac{1}{4} D r-\frac{1}{8} H r+E ; \quad \text { sendo } r \text { fixo }
$$

b.5) Média das variâncias genotípicas totais nas gerações $F_{2}$ do parental s.

$$
\bar{V}_{r s}=\frac{1}{4} D s-\frac{1}{8} H 1 s+E ; \quad \text { sendo } s \text { fixo }
$$

b.6) Covariância entre média genotípica da geração $F_{2}$ do parental $r$ e média do parental não recorrente (covariância no arranjo r).

$$
\hat{W} r s, s=\frac{1}{2} D(2)-\frac{1}{8} F r ; \text { sendo } r \text { fixo }
$$

b.7) Covariância entre média genotípica da geração $F_{2}$ do parental s e média do parental não recorrente (covariância no arranjo s).

$\hat{W} r s, r=\frac{1}{2} D(1)-\frac{1}{8} F s ;$ sendo $s$ fixo 
b.8) Covariância entre média genotípica da geração $F_{2}$ do parental r e média do arranjo do parental não recorrente.

$$
\hat{W} r s, s=\frac{1}{4} D(2)-\frac{1}{16} F r-\frac{1}{16} F(1)+\frac{1}{16} H 1(2)-\frac{1}{16} H 2 r+\frac{E}{n} ; \text { sendo } r \text { fixo }
$$

b.9) Covariância entre média genotípica da geração $F_{2}$ do parental s e média do arranjo do parental não recorrente.

$$
\hat{W} r s, r=\frac{1}{4} D(1)-\frac{1}{16} F s-\frac{1}{16} F(2)+\frac{1}{16} H^{1}(1)-\frac{1}{16} H 2 s+\frac{E}{n^{\prime}} ; \text { sendo s fixo }
$$

c) Os parâmetros genéticos são:

c.1) Distribuição dos alelos entre os parentais (Simetria).

$$
G 1=\frac{H(2)}{4 H 1(2)} ; \quad G 2=\frac{H(2)}{4 H 1(1)}
$$

c.2) Grau médio de dominância (gmd).

$$
G 1=\sqrt{\frac{H 1(1)}{D 1}} \quad G 2=\sqrt{\frac{H 1(2)}{D 2}}
$$

c.3) Direção de dominância (dd).

$$
d d=\frac{h^{2} D 1 D 2}{H(2) D 3}
$$

c.4) Proporção entre genes dominantes e recessivos (d/r).

$$
G 1=\frac{\sqrt{4 D 2 H 1(2)}+F(1)}{\sqrt{4 D 2 H 1(2)-F(1)}} ; \quad G 2=\frac{\sqrt{4 D 1 H 1(1)}+F(2)}{\sqrt{4 D 1 H 1(1)-F(2)}}
$$

c.5) Herdabilidade.

$$
\underset{h_{R}}{2}=\frac{1 / 4(D 1+D 2)}{V F 2+\frac{E}{r}}
$$




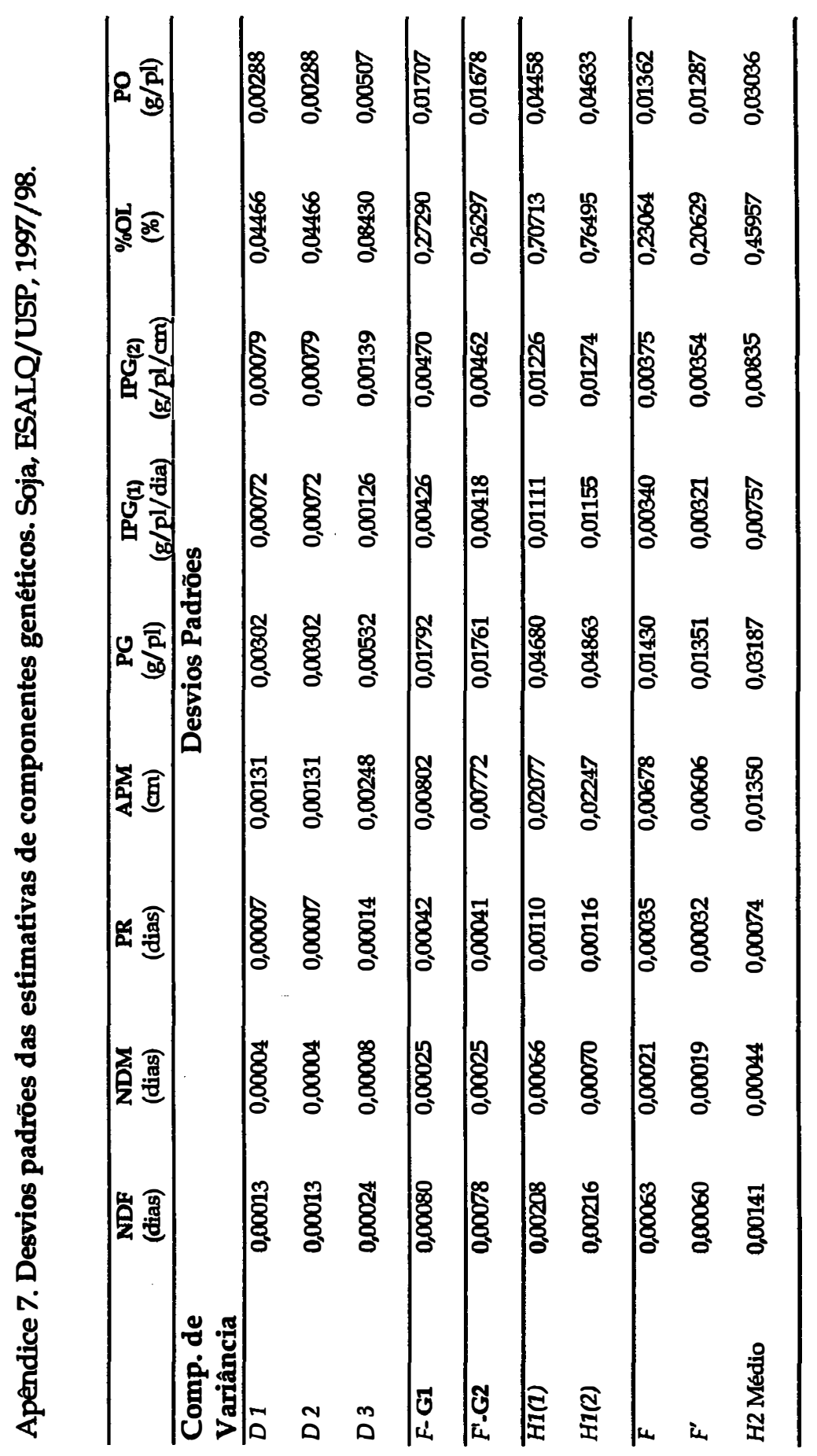




\section{ABREVIAÇÕES}

\section{Caracteres estudados}

NDF:

numero de dias para o florescimento;

NDM: numero de dias para a maturidade;

NMDM: número médio de dias para a maturidade;

PR:

APM:

periodo reprodutivo;

PG:

altura da planta na maturidade;

$\mathbf{I P G}_{(\mathbf{1})}$ produtividade de grãos por planta;

$\mathrm{IPG}_{(2):}$ indice de produtividade de grãos 1;

\%OL: índice de produtividade de grãos 2;

PO: teor de 6́leo na semente; produtividade de 6leo por planta.

4.1 e 4.2 Análises de variância individuais e conjuntas

B: blocos ( $\mathbf{j}=3)$;

E: $\quad$ épocas de semeadura $(k=3): E_{1}, E_{2}, E_{3}$.

T: $\quad$ tratamentos $(i+j+i j=53)$;

P: $\quad$ parentais $(\mathbf{i}+\mathbf{j}=13)$;

Cr: $\quad$ cruzamentos (i $\times \mathbf{j}=40)$;

$P$ vs Cr: parentais vs cruzamentos;

CP: $\quad$ ciclo de maturidade dos parentais;

CCr: $\quad$ ciclo de maturidade dos cruzamentos;

$\mathbf{P} / \mathbf{C P}^{\mathbf{P}}$ : parentais dentro de ciclo de maturidade;

Cr/CCr: $\quad$ cruzamentos dentro de ciclo de maturidade;

T $\times$ E: $\quad$ tratamentos $x$ épocas de semeadura;

$P \times$ E: $\quad$ parentais $x$ épocas de semeadura;

Cr $\times$ E: $\quad$ cruzamentos $x$ épocas de semeadura;

$\mathrm{CP}^{\mathrm{P}} \mathrm{E}$ E: $\quad$ ciclos de maturidade dos parentais $\mathrm{x}$ épocas de semeadura;

CCrx E: $\quad$ ciclos de maturidade dos cruzamentos $x$ épocas de semeadura;

$P \times E / C^{P}: \quad$ parentais $\times$ épocas de semeadura dentro de ciclos de maturidade;

Cr $\times$ E/CCr: cruzamentos $x$ épocas de semeadura dentro de ciclos de maturidade;

(P vs Cr) $\times$ E: (parentais vs cruzamentos) $x$ épocas de semeadura;

\%PS: $\quad$ porcentagem da parte simples da interação;

\%PC: $\quad$ porcentagem da parte complexa da interação.

4.4 Análise de correlação

EGD: $\quad$ efeito genético direto;

EGI: efeito genético indireto.

4.5 Análise de variância: Modelos dialélicos

G1:

G2:

CGC-G1:

CGC-G2:

CEC:

D1, D2:

$F, F^{\prime}, F-G 1, F^{\prime}-G 2:$

H1-G1, H1-G2, H2-médio: gmd:

d/r:

dd: grupo 1 de parentais $(v i=1,2, \ldots ., 5)$;

grupo 2 de parentais $(v j=6,7, \ldots, 13)$;

capacidade geral de combinação do grupo $1(g i=5)$;

capacidade geral de combinação do grupo $2(g j=8)$;

capacidade específica de combinação $(g i j=\mathbf{4 0})$.

efeitos genéticos aditivos;

medida da freqüencia de alelos dominantes e recessivos;

efeitos genéticos dominantes;

grau médio de dominância;

proporção de genes dominantes / recessivos nos parentais;

direção de dominância. 